The University of San Francisco

USF Scholarship: a digital repository @ Gleeson Library | Geschke Center

Doctor of Nursing Practice (DNP) Projects

Theses, Dissertations, Capstones and Projects

Winter 12-12-2020

\title{
Improving Clinical Communication and Collaboration Through Technology
}

Michelle Machon

michelle.m.machon@kp.org

Follow this and additional works at: https://repository.usfca.edu/dnp

Part of the Nursing Administration Commons, and the Technology and Innovation Commons

\section{Recommended Citation}

Machon, Michelle, "Improving Clinical Communication and Collaboration Through Technology" (2020). Doctor of Nursing Practice (DNP) Projects. 245.

https://repository.usfca.edu/dnp/245

This Project is brought to you for free and open access by the Theses, Dissertations, Capstones and Projects at USF Scholarship: a digital repository @ Gleeson Library | Geschke Center. It has been accepted for inclusion in Doctor of Nursing Practice (DNP) Projects by an authorized administrator of USF Scholarship: a digital repository @ Gleeson Library | Geschke Center. For more information, please contact repository@usfca.edu. 


\author{
Improving Clinical Communication and Collaboration Through Technology \\ Michelle Machon \\ University of San Francisco
}

Dr. Mary Lynne Knighten, DNP, RN, NEA-BC, Committee Chair

Dr. Juli Maxworthy, DNP, PhD(c), MSN/MBA, RN, CNL, CPHQ,

CPPS, CHSE, FNAP, FSSH, Committee Member

October 1, 2020 


\section{Acknowledgements}

Nothing I have achieved with this Doctorate would have been possible without the support of the Northern California Nurse Scholars Academy (NSA), so the first acknowledgement and sincere thanks rightly go to Kaiser Permanente and the NSA programs.

My thanks to Kaiser's SVP Linda Knodel for involving me with clinical communication in 2018, and to my very valued colleagues, Dr. Anne Marie Watkins, Dr. Janet Sohal, Debbie Reitter, RN, MSN, CNS, and Sherri Cox DNP(c) for their knowledge and support.

I was completely terrified when told Dr. Mary Lynne Knighten was my Chair, as my first semester in her class had not gone as smoothly as I had hoped for. Yet, I could not have been luckier, as Dr. Knighten has been the most wonderful support and has provided the level of academic rigor and guidance that every DNP student can only dream of. It was an honor and privilege to be mentored by her, and to publish with Dr. Knighten and Dr. Sohal on this topic.

No acknowledgement would be complete without the obligatory (and very heartfelt) thanks to friends and family. I started this DNP houseless and husbandless, challenging times indeed. Our house was uninhabitable, and my husband's green-card had no signs of being issued; therefore, he could not enter the United States. My enduring love and thanks to the Wilsons and the Brosnahans for giving me a bed to sleep in, a table to work on, love, support, and a place to cook baked beans on toast (because that is all I can cook!). You guys are family. For my wonderful Mom, Thelma - maybe now you do not have to worry about me anymore? Ciara, you got to your master's degree 15 years earlier than I got to it, you didn't lick it off the ground kiddo! I could not be any prouder of you than I am. When are you starting your Doctorate? Last but definitely not least, to my darling husband, who has now suffered through three degrees over 17 years. None of this could have been done without you, and all of it is dedicated to you. 


\section{TABLE OF CONTENTS}

\section{Section I: Title and Abstract}

Title

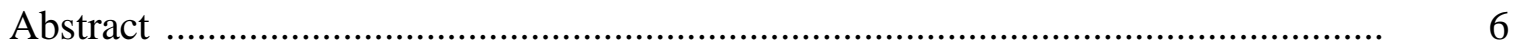

Section II: Introduction ............................................................................ 8

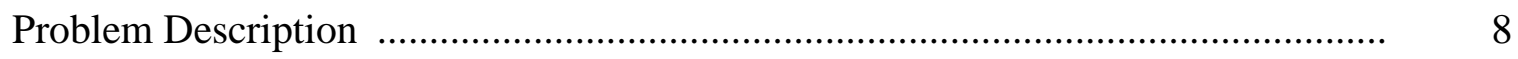

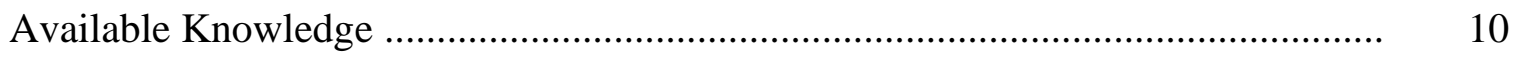

PICOT Question ...................................................................... 10

Search Methodology .......................................................................... 11

Review of the Evidence ........................................................................ 12

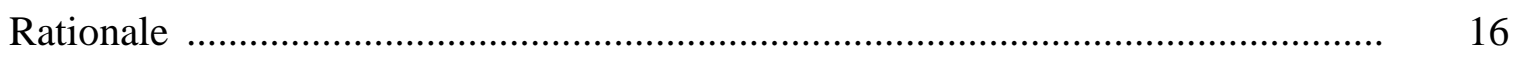

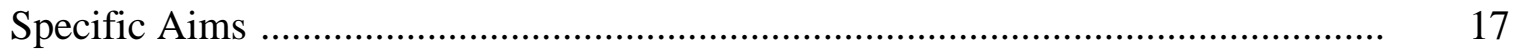

\section{Section III: Methods}

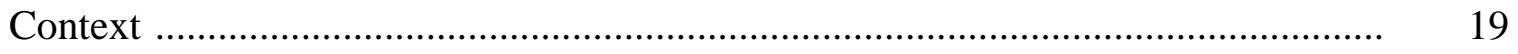

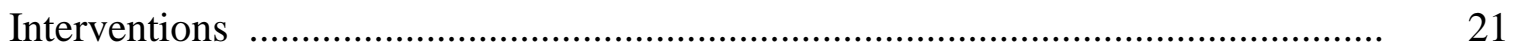

Gap Analysis .................................................................................. 21

Gantt Chart ..................................................................................... 23

Work Breakdown Structure ................................................................. 23

SWOT Analysis ........................................................................ 24

Project Budget ......................................................................... 25

Responsibility/Communication Plan ............................................... 26

Cost/Benefit Analysis ...................................................................... 27

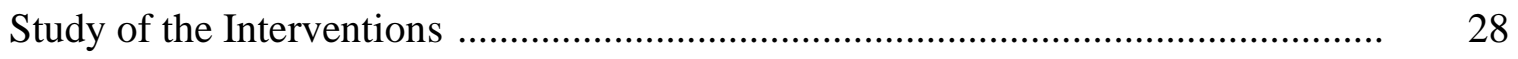

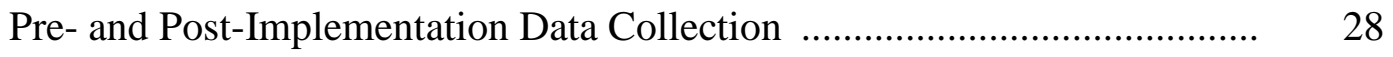

Implementation Guide .............................................................. 31

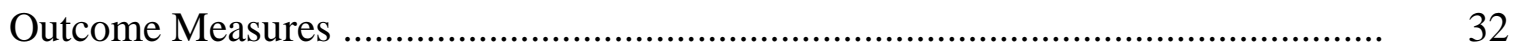

Pre- and Post-Implementation Data Collection ..................................... 33

Implementation Guide .............................................................. $\quad 35$ 


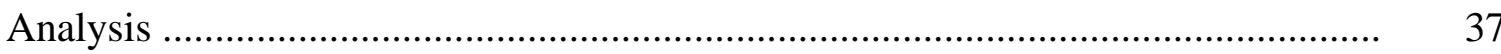

Pre- and Post-Implementation Data ......................................................... 37

Implementation Guide ..................................................................... 39

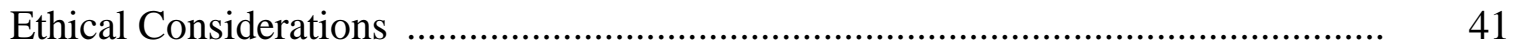

\section{Section IV: Results}

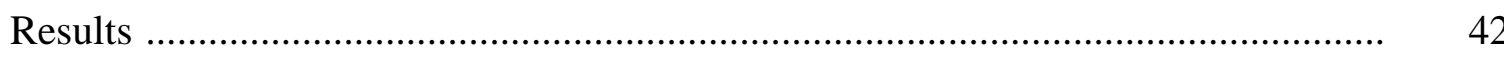

Pre- and Post-Intervention Data Collection ................................................... 42

Other Hospitals within the System Due to COVID-19 ............................. 46

Implementation Guide Intervention ................................................... 48

\section{Section V: Discussion}

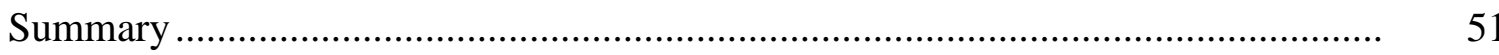

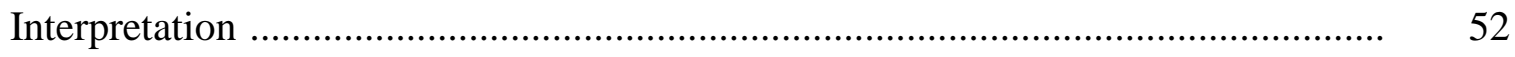

Limitations

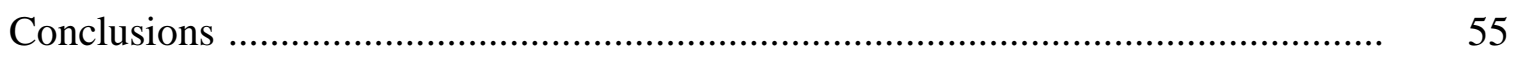

\section{Section VI: Other Information}

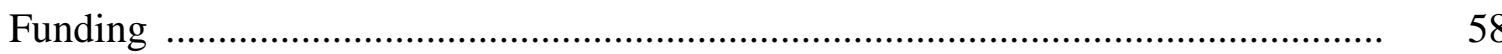

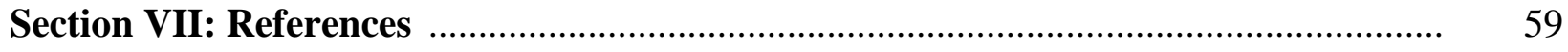

\section{Section VIII: Appendices}

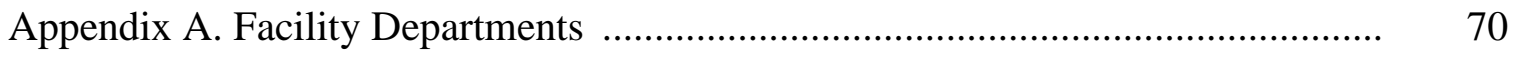

Appendix B. Go-Live Departments and Their Devices .................................. $\quad 72$

Appendix C. Current and Future Devices ...................................................... 73

Appendix D. PRISMA Flow Diagram …..................................................... 74

Appendix E. Johns Hopkins Research Evidence Appraisal Tool ......................... 75

Appendix F. Johns Hopkins Non-Research Evidence Appraisal Tool ................... 84

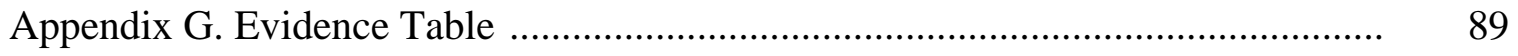


Appendix H. Capabilities of a Fully Integrated CC\&C Platform ............................ 103

Appendix I. Gap Analysis ......................................................................... 104

Appendix J. Gantt Chart (Project Only) ........................................................... 106

Appendix K. Work Breakdown Structure ....................................................... 107

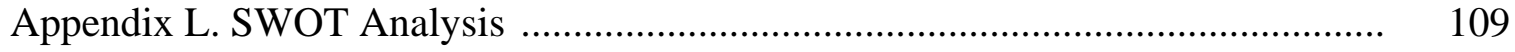

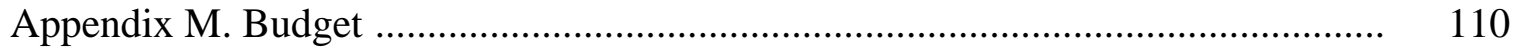

Appendix N. Communication Plan ........................................................... 111

Appendix O. Manager Letter of Participation ................................................... 112

Appendix P. Staff Letter of Participation ........................................................ 113

Appendix Q. Cost/Benefit Analysis ......................................................... 114

Appendix R. Fieldwork Guides .................................................................... 116

Appendix S. Index of Topics from Implementation Guide ................................ 122

Appendix T. Implementation Guide Online Survey .......................................... 124

Appendix U. Project PDSA Cycle .......................................................... 126

Appendix V. Letter of Non-Research Determination ...................................... 127

Appendix W. Letter of Organizational Permission ........................................... 128

Appendix X. DNP Statement of Non-Research Determination ........................... 129

Appendix Y. Detailed Results of Data Collection ................................................ 132 


\section{Section I: Abstract}

Problem: Over the last 30 years, clinical communication methodologies in healthcare have evolved to become such disparate systems that they lead to confusion, wasted time, and clinician dissatisfaction. The Joint Commission (2016) reports up to $78 \%$ of sentinel events in hospitals are linked to communication failures, which have obvious implications for hospital systems in the quality and safety of their current communication systems.

Context: The purpose of this project was to determine the effectiveness of implementing a unified clinical communication technology platform in an acute care hospital setting and to make recommendations from that implementation to the organization's larger health system. Its purpose was also to determine if the creation of a clinical communication technology implementation guide for nurse leaders would positively impact future implementations of such platforms throughout the larger health system.

Interventions: This project introduced smartphone communication technologies to inpatient nurses and other clinicians in a 352-bed hospital in California, which is part of a larger 39hospital, multi-state system. Analysis was then performed by collecting data before and after implementation of the clinical communication platform. While not part of the original plan, elements of the platform were subsequently deployed to help with clinical communication during the height of the SARs CoV (COVID-19) pandemic, and this implementation was also analyzed for the project. The intention was also to determine if the creation of a clinically focused implementation guide for clinical leaders could positively impact the application of such a communication platform throughout the larger health system.

Measures: Measures in this study included productivity, efficiency, quality of care, communication, and staff satisfaction with the newly implanted technology. Measurement 
regarding the usefulness of the implementation guide was gauged through the perceived satisfaction of nurse leaders who reviewed the guide and gave feedback.

Results: Mixed results were realized from the implementation of this technology, but the work yielded valuable information for future implementations within the organization. Frontline staff and physician satisfaction with the whole platform was low, but leadership satisfaction with the elements implemented for COVID-19 was high. For the implementation guide, nurse leaders gave valuable feedback and determined it would be a highly useful document for facility implementation leads in the future.

Conclusion: The implementation of new clinical communication technology and methodologies has the opportunity to improve productivity, efficiency, quality of care, communication, and staff satisfaction, but only if barriers to implementation are mitigated before, during, and immediately after go-live. A comprehensive implementation guide for nurse leaders can be the tool designed specifically to mitigate these barriers and prepare nurse leaders and facilities for the new technology and associated workflow changes that accompany the technology. Keywords; clinical communication, leadership, nursing, smart device, smartphone, 


\section{Section II: Introduction}

In a large, 39-hospital, seven-state, integrated health system in the United States, clinical communication is similar to the disparate systems noted in the literature. Some of the organization's facilities rely on pagers, analog phones, and the overhead paging systems, while others have smart devices and instant secure messaging systems for clinical communication and collaboration $(\mathrm{CC} \& \mathrm{C})$ among the whole care team. Communication opportunities exist at the macro-, meso-, and micro-system levels of this organization. Current literature demonstrates that clinician satisfaction improves with an optimized communication platform, and quality, patient safety, and care experience are enhanced when communication improves (Menon \& Rivett, 2019; VanDusen, 2017; Webb, Spina \& Young, 2016). Additionally, workflow efficiencies are realized when communication is enhanced, and there are projected clinical cost savings with the implementation of systems to improve communication (Brooks, 2018; De Grood et al., 2012).

\section{Problem Description}

The setting for this project was a large, seven-state, integrated health system in the United States, which has a combination of hospitals, outpatient clinics, and a self-funded health plan. There are 39 inpatient hospitals within three U.S. states in the health system. The macrosystem is disadvantaged by the multitude of different processes. From a national perspective, nursing, physician, and information technology (IT) leadership, seeking to unify communication processes for all clinicians, were preparing a business case to present to the Board of Directors. This frustration was echoed at the mesosystem (facility) level, where clinicians and leadership reported dissatisfaction in those facilities that had older communication methodologies. Six of the 39 hospitals at the mesosystem level have had a newer smartphone platform since 2015, and in the other 33 facilities, nurses were using older analog devices, while physicians were using smartphones and a standalone messaging application for providers only. At the microsystem 
level, individual clinicians expressed the same frustration with poor communication among team members, dissatisfaction with outdated technologies, and potential risks in patient care. In the six facilities where the newer technologies had been implemented, no studies had been done on the effectiveness of the solution.

KP Medical Center X (KP-MCX) is a 352-bed inpatient facility with acute care, critical care, perioperative, emergency, and maternal child services (see Appendix A for a full list of the departments in the facility). KP-MCX was the setting for this project and the inpatient units and emergency department (ED) were the last areas to go-live in the current funding cycle. Data collected before and after this implementation was to be added to the business case to seek funding for the remaining 31 hospitals in the health system. At this medical center, most departments were going live with the organizationally branded Integrated Healthcare Communication (IHC) platform which included the Vocera ${ }^{\circledR}$ clinical communication platform. Some were implementing the platform on handheld devices (Zebra® TC51 devices with the Vocera Collaboration Suite [VCS] app) and others were planning to use hands-free devices utilizing VCS on the Vocera badge device (see Appendix B for a list of the departments and the devices they were planning).

Previously in the facility, there were multiple communication methodologies. The nurses used analog $\operatorname{Cisco®} 7925$ phones to make and receive phone calls within the facility. However, they could only call desk phones or other Cisco phones (see Appendix C for a pictorial description of the devices). The only other function of these Cisco phones was to receive cardiac alarm notifications from the cardiac monitoring system and alerts from the Rauland Responder® nurse-call system. These alerts included the nurse-call button, code blue, staff assist calls, and bed-exit alarms. When any member of the team needed to contact someone outside the 
department, they went to a desk phone and paged or called the other person. This required them to then wait at the desk for the return call. There was no access to the electronic medical record (EMR) on Cisco phones, and a combination of all of these processes decreased the efficiency of the care team.

Providers used multiple methodologies to communicate with nursing and other care team members. Physicians had employer-provided pagers and Apple iPhones ${ }^{\circledR}$ on which they could receive calls and pager messages. Many providers carried employer-provided Apple iPads® to access and document in the EMR. Providers also had Imprivata’s Cortext ${ }^{\circledR}$ secure messaging application on their iPhones to message between physicians and some clinical leaders. Staff nurses could not use Cortext on their Cisco phones, therefore had no access to secure instant messaging with other team members. These multiple communication methodologies led to confusion, wasted time, and inefficiencies in care team collaboration. Because there were no messaging capabilities on the nurse's analog phones, there were also situations where clinicians had anecdotally said that they used their personal phones to send and receive messages to providers and other members of the care team. This was not a process advocated by the organization as it created the potential to cause Health Insurance Portability and Accountability (HIPAA) privacy breach concerns (Freundlich, Freundlich, \& Drolet, 2018; Przybylo et al., 2014). Five other KP hospitals in the California region had implemented this technology in the previous five to eight years, and now it was KP-MCX's turn to implement the platform.

\section{Available Knowledge}

\section{PICOT Question}

Two PICO(T) questions guided the search for available knowledge and evidence about $\mathrm{CC} \& \mathrm{C}$ in the inpatient setting: 
1. For inpatient nurses in a large hospital system $(\mathrm{P})$, does the introduction of smart-device communication strategies (I), compared to no smart-devices (C), have a positive effect on productivity/efficiency, quality of care, and communication $(\mathrm{O})$ within a six-month period post go-live $(\mathrm{T})$ ?

2. For inpatient nurse leaders $(\mathrm{P})$, could a technology implementation guide for clinical facility leads and chief nurse executives (I), compared to no guide (C), positively impact the implementation of a smart-device communication platform in their hospitals $(\mathrm{O})$ ?

\section{Search Methodology}

The Cumulative Index to Nursing and Allied Health Literature (CINAHL), PubMed, Scopus, and Cochrane databases were searched using the key terms clinical communication, secure messaging, mobility, smartphone, smart device, leadership and nursing. Given the literature search sought evidence worldwide, the key terms utilized included nomenclature more familiar in other countries including smart device and mobile phone. As there are public and private industry leading experts in unified clinical communications, a Google $₫$ search using the same key terms also contributed to the body of knowledge from expert opinions and government organizations. Inclusion criteria allowed for literature that provided information about communication from other healthcare team members, not just nursing. Exclusion criteria included published bodies of knowledge about clinical communication older than 15 years, as well as non-inpatient related communication methodologies and technologies. A total of 136 articles and expert opinions were identified in the literature review. These were reduced to approximately 60 that were included in the reference section. The Preferred Reporting Items for Systematic Reviews and Meta-Analyses (PRISMA) flow diagram was utilized to screen articles and to determine eligibility for inclusion (Moher, Liberati, Tetzlaff, \& Altman, 2009; see 
Appendix D for the PRISMA flow diagram). From the sixty articles considered suitable to be utilized throughout the document, thirteen were deemed appropriate to be included in the evidence table. In reviewing the articles for strength and quality, the Johns Hopkins Nursing (2017a, 2017b) appraisal tools were used, with permission (see Appendix E and Appendix F). This provided guidance for the research (qualitative, quantitative, mixed methods), and nonresearch articles that became the table of evidence. After appraisal, using the Johns Hopkins tool, the quantitative and qualitative evidence ranged from Level 1-A to Level III-B, and the nonresearch evidence was determined to be Level V-B (good quality). See Appendix G for a critical appraisal of key elements of the evidence.

\section{Review of the Evidence}

In 2007, the Institute for Healthcare Improvement published the Triple Aim, a framework that guides healthcare practice, research, education, and policy, with three goals: (a) improving care experience, (b) improving population health, and (c) reducing healthcare costs. (Bodenheimer \& Sinsky, 2014). In 2014, this became the Quadruple Aim, when clinician satisfaction was added as the fourth element. This provides an excellent framework for the type of improvements that could be realized if clinical communication is improved.

The Center for Health Information and Decision Systems notes that hospitals in the United States waste over $\$ 12$ billion annually due to communication inefficiencies among healthcare providers (Agarwal, Sands, \& Schneider, 2019). The average U.S. 500-bed hospital loses over \$4 million annually due to communication inadequacies, resulting in longer lengths of stay, delays in clinician contact, absence of standardized workflows, poor alarm/alert management, high cognitive burden, lack of information in clinicians' hands, fragmented clinical directories, missed escalation opportunities, and the inability to know what staff were on duty 
(Agarwal et al., 2019; Higgins et al., 2017; Ponemon Institute, 2014). Additionally, the literature demonstrates inefficient resource utilization, ineffective core operations, slower inpatient admission times, doubled emergency response times, avoidable admissions and readmissions, and decreased patient and staff satisfaction; all of which impact healthcare quality and patient safety (Agarwal et al., 2019; Higgins et al., 2017; Ponemon Institute, 2014). With 19\% of nurses' time spent communicating (Chatterjee, Chakraborty, Sarker, Sarker, \& Lau, 2008), the importance of an adequate CC\&C platform cannot be over-emphasized. Enabling clinicians to communicate more effectively will help organizations achieve the Quadruple Aim, as well as meet this health system's mission to provide high-quality, affordable healthcare services.

Healthcare is in an era where efficiency, access to information, and improved communication methodologies are becoming as vital to the performance of our nursing role as the skills described by Florence Nightingale "to provide a safe and caring environment that promotes patient health and wellbeing" (Selanders \& Crane, 2012, p. 1). Tools that provide HIPAA compliant secure messaging; smartphones with voice, messaging, and group chat capabilities; wearables that allow hands-free communication; and devices that host a variety of useful clinical applications are examples of these types of technologies in healthcare. Also, processes that lead to standard work, including standardizing clinical communication, provide "higher reliability, better care, and improved patient outcomes, eliminate non-value-added waste, and optimize existing value resulting in reduced errors, improvements in quality, and reduced burden of work for staff” (Boettcher, Hunter, \& McGonagle, 2019, p. 152).

The general benefits of smartphones, mobile platforms, and messaging methodologies in healthcare are well documented in academic literature and general publications (Bautista, Rosenthal, Lin, \& Theng, 2018; Brooks, 2018; Martin et al., 2019; Mickan, Atherton, Roberts, 
Heneghan, \& Tilson, 2014; Motulsky et al., 2017; Patel, Siegler, Stromberg, Ravitz, \& Hanson, 2016; Runyon, 2018; VanDusen, 2017; Whitlow, Drake, Tullman, Hoke, \& Barth, 2014). However, when we look at quality and safety benefits, the literature is specific. Tethering clinicians to landlines, emails, pagers, and intercoms through lack of a mobile device causes quality and safety problems: such as care delays, decreased throughput, and potential medical errors (Brooks, 2018; Patel et al., 2016). The introduction of smartphones has been associated with enhanced interprofessional communication (Martin et al., 2019; Patel et al., 2016; VanDusen, 2017), improved handoffs, faster response times, less disruption to clinical workflows, improved interprofessional interactions, and reduction in redundant tasks and care delays (Brooks, 2018; Martin et al., 2019). The ability to access information for clinical guidance, policies, and improved clinical decision-making has also been noted (Mickan et al., 2014).

In a deductive study, which reviewed the literature around the use of mobile devices in healthcare, Chatterjee et al. (2009) reported a reduction in delays in healthcare services and an improved ability to monitor critically ill patients. Quality of care was enhanced through the diagnosis of pediatric skin conditions when pediatric images were transmitted by smartphones (Devrim et al., 2019) and through a significant rise in electronic prescribing (from 53\% to 64\%) and better clinical decision-making (Brown-Manhertz, 2017). Motulsky et al. (2017) demonstrated a 51\% increase in accuracy in handoffs for all units with the introduction of a smartphone handoff and rounding tool. De Grood et al. (2012) reported that their wireless communication device implementation "did live up to its aims of enhancing communication, staff efficiency and improving perceived patient safety" (p. 154). Astarcioglu et al. (2015) described a door-to-balloon time improvement of 16\% (21 minutes faster) after implementing a 
messaging application. Jeon and Park (2015) found that mobile interventions in nursing led to significant improvement in weight and glucose control among their patients. Multiple authors reported the time savings of a clinical communication platform (Agarwal et al., 2010; Breslin, Greskovich \& Turisco, 2004; Mehrzad \& Barza, 2015; Menon \& Rivett, 2019; Vermeir et al., 2015; Whitlow et al., 2014). Within the scientific underpinning of practice context (American Association of Colleges of Nursing [AACN], 2006), it is worth relating these findings to Aiken, Clarke, Sloane, Sochalski, and Silber's (2002) study, which demonstrated that in hospitals with over-burdened nurses, the risk-adjusted 30-day mortality is higher, as is nursing burnout and job dissatisfaction.

Menon and Rivett (2019) conducted a mixed methods study, including time and motion studies, interviews, and a survey, which demonstrated efficiencies in discharge patient flow, improvement in speed of getting discharge medications to nurses (by 10 minutes), and reduction of medication errors after the introduction of a messaging system in their organization. One organization reduced ED utilization in their opioid-seeking population by $73 \%$ by using their clinical communication platform to alert staff when those patients presented to the ED. However, as Brooks (2018) stated in this expert opinion, "More important, the (ED) care managers were able to refer these patients to the opioid-abuse rehabilitation and behavioral health resources they needed" (p. 5).

Other enhancements included real-time access to clinical information reduced ED visits and inpatient bed utilization, improved organization of daily activities, improved care coordination, and improved clinician satisfaction (Brooks, 2018; Mickan et al., 2014; Patel et al., 2016; VanDusen, 2017). Finally, improvements in rounding, handoffs, and collaborative documentation practices were reported in a quantitative study by Motulsky et al. (2017). These 
improvements all lead to the improved quality and safety of patients, which is necessary to meet Essential II of The American Association of Colleges of Nursing's 'Essentials of Doctoral Education for Advanced Nursing Practice' which discusses doctorally prepared nurses improving organization and systems leadership for quality improvement and systems thinking (AACN, 2006).

From a quality and safety perspective, no communication platform is without concerns. HIPAA violations, risk of distractions, usability and task load, appropriate use, form factor (shape), legal issues, sound quality, the myth of dependability, and the potential for worsening relationships have all been documented in the literature (Al Thomairy, Mummaneni, Alsalamah, Moussa, \& Coustasse, 2015; Chari \& Gane, 2018; Drews, Zadra, \& Gleed, 2018; Gill, Kamath, \& Gill, 2012; Health Information Management and Systems Society, 2018; Hughes-Driscolla, Gurmub, Azeem, \& El Metwally, 2018; Kuhlmann, Ahlers-Schmidt \& Steinberger, 2014; Lo, Wu, Morra, Lee, \& Reeves, 2012; Maryn, Ysenbaert, Zarowski, \& Vanspauwen, 2017; McBride, 2015; Redelmeier \& Detsky, 2013; Ross \& Forgie, 2012; Thomas, 2013). These are concerns that must be addressed in any communication platform implementation, due to their potential effect on the quality and safety of patient care.

The evidence clearly demonstrates that care-quality improves with enhanced clinical communication. This project asked if the introduction of smartphone communication strategies would have a positive effect on productivity/ efficiency, quality of care, and communication for inpatient nurses in a large hospital system within a six-month period post go-live. The PICOT question was not met in this facility compared to other implementations described in the literature, however it is believed that the learnings taken from the go-live in KP-MCX will help other hospitals within the health system. 


\section{Rationale}

The conceptual framework from three theories guided this project. Rogers' diffusion of innovation theory (Doyle, Garret, \& Currie, 2014), Klein and Sorra’s (1996) implementation framework, and Michel-Verkerke and Spil's (2013) USE IT-adoption-model represented the concepts demonstrated with this technology implementation.

Rogers (as cited in Doyle et al., 2014) originally developed the diffusion of innovation theory in 1962 in two categories. First, Doyle et al. (2014) discussed adoption of innovation at the individual and organization level. At the adoptee level, Rogers categorizes people as being either innovators, early adopters, early majority, late majority, or laggards. Doyle et al. further described the five stages of innovation as knowledge, persuasion, decision, implementation, and confirmation. This was particularly important in the development of an implementation guide for staff receiving the communication platform and helped address the concerns of the laggards, while harnessing the enthusiasm of the innovators and early adopters.

Klein and Sorra's (1996) implementation model detail a process that determines the effectiveness of an innovation implementation in an organization. How well an innovation is adopted is a result of the organization's climate and the organization's employees' perceptions of the fit of the innovation within the organization's values. This communication platform will eventually be implemented in 33 hospitals in three different U.S. states, so making the best effort to know the meso and micro-systems culture, their values, and the climate will be important.

Michel-Verkerke and Spil's (2013) USE IT-adoption-model also predicts and evaluates the adoption of innovations; specifically, information system (IS) innovations in healthcare. There are four determinants to the success of the adoption of IS systems: relevance, 
requirements, resources, and resistance. In this model, the determinants are measured both organizationally and at the individual (end-user) level (Michel-Verkerke \& Spil, 2013). This organization previously had some difficult large-scale IT implementations in recent years, so integrating the four elements of the USE IT-adoption model helped to assess the organization's readiness and control these challenges and ultimately, was utilized to assess the success of this communication platform implementation.

\section{Specific Aims}

The aim of this project was to develop, implement and evaluate a clinical communication program by providing expert information to the leadership of a national health system as they move forward utilizing technology to improve clinical communication. The project determined the effectiveness of the implementation of a unified clinical communication platform in one acute care hospital in order to make recommendations to the larger organization. This evidencebased change of practice project included analyzing productivity/efficiency, quality of care, and communication for inpatient nurses and other members of the interprofessional care team. Since previous implementations were driven by IT, the project also aimed to determine if the creation of a clinically focused implementation guide for nurse leaders would positively impact the golive of such a communication platform. 


\section{Section III: Methods}

\section{Context}

This health system has a presence in seven of the United States and has 39 hospitals in three of those states. In the hospital setting, clinical communication through technology has changed over the years by adding clinician devices in a haphazard manner, with the result that many clinicians carry up to five devices for clinical communication. Figure 1 illustrates the devices one physician carries on a regular workday in the organization.

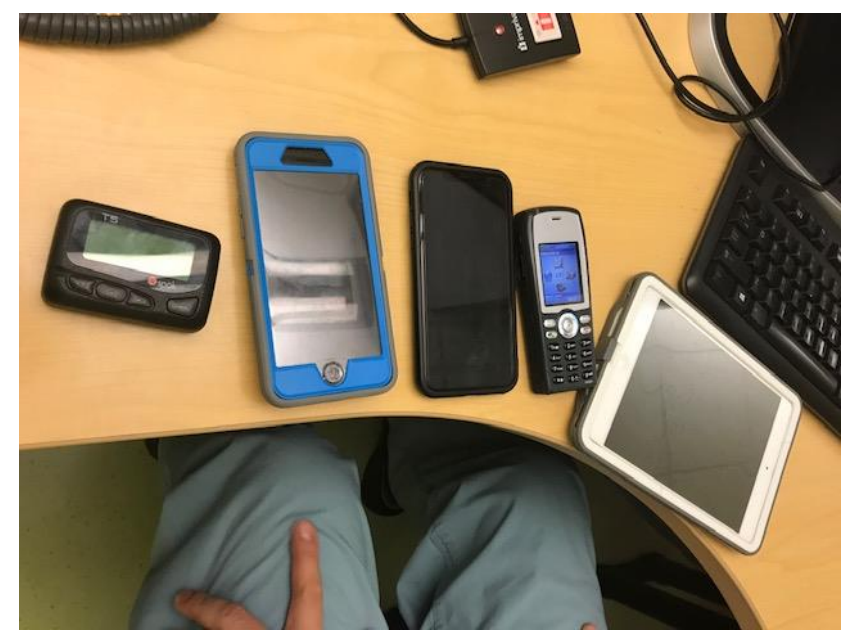

Figure 1: Devices carried by a physician in a San Francisco hospital, January 6, 2019.

For nurses, there is a mix of devices between the facilities in the health system, with some carrying older analog phones, whose only function is to make calls and receive alerts/alarms, and some carrying newer smart devices. Four years previously, nurses and other clinicians in some of the Southern California facilities had moved to these smart devices with the VCS application in a platform that KP had named integrated healthcare communication (IHC). The capabilities of the IHC platform are listed below (see Appendix $\mathrm{H}$ for a full list of the potential capabilities of clinical communication platforms in healthcare today). The hardware 
devices include Zebra TC51 mobile computing devices and the Vocera hands-free badge device. Software capabilities of the platform include:

- Voice calls

- $\quad$ Secure two-way instant messaging

- Access to view and document in the EMR

- Clinical directory with ability to see who is in the hospital at any given time

- Group messaging

- Role-based calling and messaging

- Alert and alarm delivery

- On-call directories

While six of the 39 facilities within the organization had already implemented the IHC platform, no performance improvement data were collected before, during, or after these implementations, and now, the KP-MCX facility was going live with smart devices and the VCS application.

The key stakeholders for this project included leaders and frontline staff at the macro, meso, and microsystem levels of the health system. These stakeholders were highly motivated to see a unified clinical communication platform implemented across the health system. All levels of the facility were aware of and supported improving clinical communication in the organization; although, some levels were more informed than others about the change. As an added incentive, KP-MCX was actively seeking designation by the American Nurses Credentialing Center's (ANCC) Magnet Recognition Program ${ }^{\circledR}$ at the time, and the Magnet nurse leaders were very interested to have a nurse-led project submitted to the KP Institutional Review Board (IRB) process. The project proposal was presented to their shared governance committees, with very positive feedback. The nurse leaders at KP-MCX were encouraged to 
nominate two frontline staff nurse co-leads for the project to build their research skills. Two staff nurses were identified to help with the data collection, with help also provided from the nursing director co-lead of the Research Shared Governance Council.

\section{Interventions}

The interventions for this project were two-fold:

1. Collect data before and after the facility's IHC go-live to inform the larger organization about the effects of the implementation of a unified clinical communication system at that facility.

2. Create a clinically focused implementation guide to assist future facilities with the implementation of the platform and seek input from nursing leaders regarding the value of the guide.

Before determining the exact details of the interventions, a gap analysis was conducted, a Gantt chart was developed to determine the critical milestones that lay ahead, and a work breakdown structure listed the tasks necessary to conduct the project. An analysis of strengths, weaknesses, opportunities and threats (SWOT) was also performed, detailing the current state of clinical communication in the organization at the time.

\section{Gap Analysis}

There were multiple focus areas for analysis of gaps related to this project. These included clinical communication at the larger organizational level, the facility level, the clinician level, and the implementation level (see Appendix I for the full gap analysis).

Health system level. At the organization level, only $15 \%$ of the larger organization had the whole clinician team on a smartphone platform with a unified clinical communication process. The other $85 \%$ had a mismatched system of smartphones, pagers, analog phones, and 
different communication applications, as well as a reliance on older technologies, which places the organization at risk due to poor communication.

Facility level. At KP-MCX specifically, hospital leadership were dealing with different communication methodologies in different situations. The lack of standard work processes is a challenge for healthcare leaders who are seeking to "reduce waste, ensure patient safety, improve flow, and achieve balanced and synchronous production of healthcare standards" (Boettcher et al., 2019, p. 153). For KP-MCX leadership, the goal of moving to a standard clinical communication methodology could close the gap by "best utilizing people at their various levels of licensure while keeping the rhythm of hospital operations tied to the flow of patient requirements" (Boettcher et al., 2019, p. 153).

Clinician level. Clinicians without a unified platform were using different and often creative, but inefficient, methods to communicate. One nurse in the post-anesthesia care unit (PACU) summarized the gap effectively,

When I need a surgeon, I will start by paging them, then I will try to call them on their work phone. If I cannot find them that way, I will send a text message to their personal phone, then call their personal phone. Then I will call over to the OR. If none of those ways work, I will walk over to the OR to see if they are there (PACU RN, personal communication, January 4, 2019).

These inefficiencies created delays in care, frustration, anger at times, and risk or quality of care concerns.

Implementation level. From the implementation perspective, the previous six go-lives were led solely by IT. While the project management principles of initiation, use of tools, scope and expectation delineation, scheduling, technology design, cost control, risk avoidance, 
performance reporting, and project closure (Martinelli \& Milosevic, 2016) were used appropriately, there was no specific toolkit for the changes from a clinical perspective. A guide or toolkit might include guiding the facility leadership and multi-disciplinary clinical groups in the clinical rationale and evidence in the literature for the change, along with the clinical versus technological steps for implementation of the new processes and technologies.

\section{Gantt Chart}

One method to visually demonstrate the schedule, activities, timelines, level of detail, responsibilities, and resources of a project is a Gantt chart (Martinelli \& Milosevic, 2016). The Gantt chart for this project included both the activities for the academic milestones for the project lead, broken down by semester, as well as the specific activities around the project. The Gantt chart had two main sets of deliverables: one set required for the course itself and one set for the milestone deliverables for the project. Included in the course deliverables were attendance at the course intensive sessions, delivery on all papers and assignments, completion of a prospectus for the project, writing a manuscript for publication, obtaining a national nursing certification, and authoring and orally presenting the final project. The project milestones include detailed research on the topic of CC\&C, a review of the evidence, data collection pre- and postimplementation of the technology in the facility in Southern California, and the creation of an implementation guide for future facilities (see Appendix $\mathbf{J}$ for the full Gantt chart for the project work).

\section{Work Breakdown Structure}

A work breakdown structure (WBS) details a collection of the elements or tasks that are within the scope of a project. The benefits of developing a WBS include defining what is within and out of scope for a project; helping to keep a project on track, within budget, and on schedule 
(Kaufman, 2005); and providing a way to ensure projects have "manageable increments [that are] planned, organized, and controlled" (Martinelli \& Milosevic, 2016, p. 126). There was one WBS for the collection of data for the implementation of the technology and one WBS to create an implementation guide that detailed the planning, preparation, and execution of the technology and associated changes in practice expected by the implementation. The project did not include the ongoing support and maintenance of the project after implementation (see Appendix $\mathrm{K}$ for a tree structure view of the WBS for this project. To outline the work breakdown structures for this project, the first level of work elements (L1) in both WBS diagrams determined the highest level of work effort and all subsequent work elements stemming from this level.

Work breakdown structure one. The work elements for this project stemmed from the six branches of L1: building the business case, obtaining funding, managing the software and hardware, pre-implementation data collection, post-implementation data collection, and data analysis/recommendations.

Work breakdown structure two. In the second WBS, the work of creating an implementation guide was described. There are six first level work elements (1.1 to 1.6), and the most important first level elements in this WBS are those of gathering information about implementation guides, creating the implementation guide, and then testing the guide with live and non-live sites $(1.4,1.5$, and 1.6).

\section{SWOT Analysis}

A SWOT analysis is a way to ask, "What are the features or components of the organization and its external context that are key to success ... that allows the organization to consider the risks that will impact these dependencies" (Hopkins, 2018, p. 27). Since the focus of this project was at a facility, the SWOT analysis was focused at the facility level. Strengths of 
the project included strong organizational support at the facility to improve clinical communication among the team, and the facility was self-funding the implementation outside of the national project. Another strength was the strong support in the literature for such implementations, and this evidence has been proven over a 15 -year period. The opportunities observed were to improve and unify clinical communication, as well as improve quality and safety of patient care. Issues with disparate communication methodologies were seen at the facility, and the opportunity to improve this was supported in the literature. Threats to the project included potential problems with the wireless infrastructure, which risked the stability and functionality of the technology post go-live, if not remediated. Support post go-live was also a threat, with no support staff planned to manage the application and hardware postimplementation. Finally, the project's weaknesses included a lack of a clear clinical implementation framework and a lack of policies and guidelines for the post-implementation timeframe (see Appendix L for the full SWOT analysis).

\section{Project Budget}

While the IT return on investment (ROI) is clear, the clinical ROI for this platform is not necessarily in the form of hard-dollar savings, such as the ability to reduce full-time equivalent (FTE) staff count or a hard-dollar decrease in departmental spending. However, the soft-dollar clinical ROI is considerable in the form of quality, safety, and clinician and patient satisfaction. Therefore, a proposal was brought to the health system's executive funding body, which stated that a clinical business partner (CBP) role was needed to work within the IT team. This role was to bring the clinical perspective to the business case and to present the clinical ROI for this unified communication system. Subsequently, $\$ 140,000$ of funding was allocated to pay for the project lead's 0.5 FTE wage over a nine-month period in order to correlate the evidence for the 
business case. This funding also included travel and expenses. With a facility identified that was going live with this technology, it was decided that part of the CBP's funding could also be used to collect the pre- and post-implementation data. In the five months prior to data collection, the CBP utilized only approximately $35 \%$ of the monthly funds allocated, and the project's executive sponsors agreed that the remaining funds could be re-allocated to contract with the organization's non-clinical research team and to engage a registered nurse (RN) project assistant to help with data collection and analysis. Over the nine-month period, the budget had not been fully utilized, and a $\$ 22,000$ positive variance was still in place. The facility requested to have two RN co-leads for the project, and the cost of their wages for the data collection period was covered by the facilities nursing department budget. See Appendix M for a month-by-month explanation of the budget.

\section{Responsibility/Communication Plan}

The communication plan for this project involved multiple levels at the health system, facility, and clinician levels, as well as with the project lead's academic advisors. See Appendix $\mathrm{N}$ for the full communication plan.

Health system level. The executive sponsors for the implementation of this unified clinical communication platform were the IT vice president (VP) of Care Delivery Technology Services and the nursing VP of National Patient Care Services at the health system level. They were the senior national-level leaders who approved the data collection project in the facility. As such, all permissions, information, and results were reported to them and the leadership communication project team on a bi-weekly basis. Also, because funds were released to contract with the organization's Research Department, a bi-weekly communication plan was outlined 
between the project lead and the research team members to facilitate the planning and execution of the data collection and analysis.

Facility level. The key stakeholders at the facility level were the patient care services (nursing) and the physician and pharmacy leadership teams. These leaders were contacted at the start of the project to request permission to conduct the data analysis at their facility. Since the facility was on the ANCC's Magnet Recognition Program journey, the project team conducted a site visit in the summer of 2019 and attended the monthly shared governance day to explain the aims of the project to seven different leadership councils. The facility's Magnet team asked if there could be RN co-leads from the facility, and calls were arranged with these frontline RNs to strategize about the data collection process and the role of the co-leads. Finally, the nursing director lead of the Research Shared Governance Council and the manager of Clinical Informatics at the facility became the main points of contact for the day-to-day scheduling and logistics of the project, and frequent calls with them were also arranged.

Clinician level. Once the project was approved by the facility leadership team, letters were sent to the department leaders seeking their help in recruiting participants for data collection (see Appendix O). Once the managers identified willing volunteers, they were asked to give a letter to each of the participants (see Appendix P).

\section{Cost/Benefit Analysis}

Martinelli and Milosevic (2016) noted that a feasibility assessment is "the heart of a project business case" (p. 70) and includes both the tangible and intangible benefits detailed in quantifiable terms, such as dollars saved or gross margin increase. While the benefits of improved communication have been demonstrated in the literature in terms of quality, efficiency, and staff and patient satisfaction, no formal ROI studies had been done in the already live KP 
sites, so an ROI for KP was difficult to determine for this project. Certainly, there was a projected cost avoidance in preventing quality and risk events; however, this was difficult to convert to tangible benefits. Instead, two examples from the literature were included in the national business case. These examples were improved discharge time by over 22 minutes (Siwicki, 2018) and improved operating room efficiency by five minutes per case (Hearon, 2018). These were calculated for one facility in KP in terms of RN staff wage efficiencies, and then multiplied by the 39 hospitals in the system to demonstrate a potential cost avoidance of \$68.6 million dollars over four years (see Appendix Q for the cost avoidance analysis for these two measures).

\section{Study of the Interventions}

There are two interventions to study in this project: the pre- and post-IHC implementation data collection and the implementation guide.

\section{Pre- and Post-Implementation Data Collection}

Once KP's national IHC governance team determined that KP-MCX was interested in the study, the organization released funds to obtain assistance from the KP User Experience (UX) Research Department. The UX team were fully briefed on the objectives of the study and the evidence surrounding clinical communication in healthcare and were educated on the conceptual frameworks that determined how end-users accept technology. Technology and clinical communication surveys from the literature were reviewed in detail (Chen, Park, \& Putzer, 2010; De Grood et al., 2012; Hoonakker, Carayon, \& Cartmill, 2017; Johnson et al., 2015; Joseph et al., 2013; Koivunen, Niemi, \& Hupli, 2015; Mehrzad \& Barza, 2015; Moore \& Jayewardene, 2014; Motulsky et al., 2017; Nagler et al., 2014; Rozario, 2018; Whitlow et al., 2014; Wu et al., 2015), as well as the reports of the communication challenges that KP nurses were already 
experiencing. This provided the appropriate background for the project lead and the UX department to design the de novo pre- and post-implementation collection tools. The team took these four existing validated and reliable formats: focus groups, one-to-one interviews, direct observations, and online surveys, and utilized them for the data collection at the facility.

The in-person pre- and post-data collection interviews were administered three weeks pre- and five weeks post-implementation and were specific to clinical communication methodologies in the organization at the time of interview, thus ensuring the outcomes were explicitly related to the intervention. To ensure consistency in the data collected, fieldwork guides for the focus groups, interviews, and direct observations were designed by the project lead and provided to all data collectors (see Appendix R for copies of the fieldwork guides and interview questions). The interviews and focus groups were recorded for ease of data collection, and consent to record forms were signed electronically by all participants. Participants included nurses, pharmacists, physicians, and unit assistants in order to obtain a cross-section of the most common users of clinical communication technology in the interdisciplinary team. The facility staff nurse co-leads were instrumental in assisting with the scheduling of rooms, facilitation of schedules, and arrangement of staff to attend the meetings.

Focus groups. Focus groups were chosen as a methodology because they identify themes and "uncover relationships between motives, beliefs, attitudes and behaviors" (Taylor, Kermode \& Roberts, 2006, p. 411). They also allow for a more comfortable environment for participants who may feel intimidated by face-to-face interviews (Liamputtong, 2013). Each clinical group had one or more focus group sessions, offered as lunch-and-learn sessions to facilitate attendance. 
One-to-one interviews. The same categories of staff were sought to be interviewed oneto-one. In some cases, these one-hour interviews were with the same people as in the focus groups, but in most cases, these were different staff than the focus groups. Departmental directors and managers assisted in facilitating the interviews. According to Polit and Beck (2018), while they are expensive, interviews "yield high quality data" (p. 220), and semistructured interviews, like the ones performed in KP-MCX, encourage participants to talk freely about many topics. It was found that the one-to-one interviews gave the interviewers the opportunity to ask probing questions, when needed.

Direct observations. To determine how the clinicians were communicating with each other in different situations, the data collection included direct observations before and after the implementation of the new communication system. Polit and Beck (2018) noted that direct observations are beneficial, as they provide an observation of "specific behaviors, actions, and events" (p. 172), as well as provide the opportunity to capture data when people cannot fully describe their behaviors.

Surveys. Finally, short online surveys were used to capture any other information that may have been missed from the focus groups, interviews, and observations. The use of a survey followed Liamputtong's (2013) recommendation to gather larger amounts of data in small periods of time, to ask more "sophisticated questions, and to file data easily and efficiently" (p. 1999). The survey was distributed to staff on the hospital's email and intranet, and posters were provided for the facility leaders to post with a quick response $(\mathrm{QR})$ code for ease of scanning directly to the survey. 


\section{Implementation Guide}

Nurse leaders at the six live facilities had previously provided feedback that they found the go-lives very IT-driven. Previous implementations of this communication technology were focused on the functionality of the technology and the tasks necessary for go-live. Davies, Walker \& Grimshaw (2003, as cited in Nilsen, 2015, para. 4) reported that implementation science theories show that "only $10 \%$ of studies provide an explicit rationale for their strategies [and] poor theoretical underpinning makes it difficult to understand and explain how and why implementation(s) succeed or fail". The guide incorporated the process models (translating research into practice), classic theories (explaining what influences implementation outcomes), and evaluation frameworks (evaluating the implementation) that Nilsen (2015) described for highly effective implementations. The intent of the guide was to present the clinical significance of the technology and the organizational workflows that were changing with the implementation and to consider the clinicians' perceptions of the fit in their organization. The aim was to create a more clinically-focused, step-by-step implementation guide for facility nursing leads that presented rationales, timelines, duties, expectations, and guidance upfront to prepare the lead for what was coming ahead of time (see Appendix $\mathrm{S}$ for the implementation guide index of contents).

The approach chosen to assess the usefulness of the guide was to ask nurse leaders throughout the organization to read the newly-created guide and then determine its usefulness by providing direct verbal feedback or by completing an online survey (see Appendix T for implementation guide online survey). The live sites were also asked to give detailed input into areas that might be missing from the guide. The online survey was sent directly with the implementation guide, with a requested two-week turnaround time, again ensuring the feedback 
was related specifically to the implementation guide. A plan, do, study, act (PDSA) methodology was utilized to confirm that the observed outcomes of this project were due to the interventions implemented and to ensure the "circular approach to project performance improvement" was confirmed (Martinelli \& Milosevic (2016, p. 253). See Appendix U for the project PDSA.

\section{Outcome Measures}

Understanding the effectiveness of a clinical communication platform was the desired outcome of this project and the measures chosen to determine this were productivity/efficiency, quality of care, and communication for inpatient nurses as well as other members of the interprofessional care team in a 320 bed acute care hospital in California. The interventions to ascertain if these outcomes were achieved included eight focus groups, 16 shadowing sessions, 31 one-to-one interviews and surveys with 106 responses received. Themes were identified from the results of these interventions and when reviewed under the framework of the outcome measures, these included:

- productivity/efficiency: inability to realize the full potential of a technology that was not fully functioning, nor was it completely understood after training

- quality of care: the agreement that there was a potential to improve the quality of care once the immediate issues were resolved

- communication: the need for a strong Wi-Fi infrastructure to support the new technology in the communication pathways being implemented.

A secondary outcome of this project was the value a clinical implementation guide could bring to future installations of the technology. The learnings from the implementation were transferred as knowledge points into the implementation guide and satisfaction with this was measured through a survey which was sent to six CNEs and 12 informatics nurse and non-nurse 
leaders, with overwhelmingly positive responses received from all respondents (two of the CNEs and 11 of the 12 informatics leaders).

\section{Pre- and Post-Implementation Interventions}

For the data collection at KP-MCX, the tools described were carefully chosen to gather the maximum amount of data in a short period of time before implementation and then five weeks after implementation. All of the tools utilized were well received by the contributors, but participation was somewhat challenged due to high census during both visits (pre- and postimplementation). While Polit and Beck (2018) state that the cost of having face to face focus groups are an expensive method of data collection, the data yielded from this level of interaction were significant, and was very successful, as it led to gathering rich information about the implementation and reduced barriers in the post implementation data collection period. Being onsite for the three days pre- and four days post-implementation allowed the team to ensure they had the complete and accurate data needed for the pre- and post-implementation comparisons and also allowed the team to pivot when they needed different participants to complete the data collection. By collecting data from the multidisciplinary team, it ensured that different perspectives were observed. Ultimately, this created a collaborative approach where nurses discussed their interactions with providers, pharmacists talked about how they communicated with unit assistants, providers discussed how they interacted with nurses, and unit assistants discussed their collaboration with the whole team.

Written information in the form of letters was provided to all leaders and frontline volunteers from the onsite co-leads before the team arrived on site. The letter stated that anonymity was assured. The focus group and interview sessions were recorded for ease of data collection, and a signed permission to record was obtained from the participants. Since there 
were four people performing the data collection, the team ensured interrater reliability by creating written interview tools and by having the four leads meet with the facility co-lead RNs to discuss in detail and agree upon the questions and processes for interviews and observations. The first interviews, observations, and focus groups were conducted in pairs to ensure each member of the interviewing team was consistent in their methodology and interrater reliability was confirmed.

Interview techniques followed Liamputtong's (2013) recommendations for creating a comfortable environment, relaxing the participants, providing the context for the interviews, facilitating the flow of information, providing open-ended questions that allowed participants to respond naturally in their own words, managing both verbose and quiet participants, and closing the sessions on a positive note. By following evidence-based practices for interview techniques, the team felt they had assured both the quality of the data received and the adequacy of the data collected.

The observation techniques utilized included standardizing the approach with the four data collectors, where they observed, asked questions, recorded information, and interacted closely with their participants to gain insights that might have "eluded the team through a more passive approach" (Polit \& Beck, 2018, p. 206). During the observations, the team utilized elements of Polit \& Beck's (2018) process of noting the physical setting, participants, activities, frequency and duration of the observation, the process, and outcomes of the observations. After all sessions, each data collector sent a personalized thank-you card to the participants to ensure they understood the team's gratitude for their participation. The interview questions, direct observations, and survey questions collected at baseline (pre-implementation) and postimplementation were the same questions but asked with a different emphasis. In the pre- 
implementation phase, the questions were asked around the participants' current (preimplementation) communication hardware and software, while the post-implementation interviews, observations, and surveys clearly delineated that the team was asking about the new technology. Since recordings could not be done during observations, detailed notes from the observation sessions were typed and collated for analysis later.

\section{Implementation Guide}

Material for the creation of the implementation guide intervention involved the collection of data from several sources:

- Information was obtained from the literature about technology adoptions, in general, and the elements that can lead to their success. The literature was also a rich source of data from other organizations that had implemented similar technology and had made suggestions for the implementation (De Grood et al., 2012; Hoonakker et al., 2017; Johnson et al., 2015; Koivunen et al., 2015; Machon, Knighten, \& Sohal, 2020; Moore \& Jayewardene, 2014; Nagler et al., 2014; Wu et al., 2013), as well as evidence-based models and frameworks (Chen et al., 2010; Doyle et al., 2014; Klein \& Sorra, 1996; Michel-Verkerke, \& Spil, 2013).

- Direct observations of sites within KP that were already live with the technology were conducted. Feedback from frontline nurses and nurse leaders about their implementations, as well as their experiences with using the technology shift-by-shift, was a valuable source of information for the guide. Already live sites reported frustrations in accessing staff due to voice recognition, the cognitive burden from the clinical alarm notification system, and a dislike of the weight of the device. These were all elements that could not be changed in the next implementations, but could be 
recognized, and future facility leads could be prepared for this with the implementation guide.

- Observations from the pre-implementation processes at KP-MCX were also included. These sessions were led by an experienced IT project manager who had previously led the six other implementations within KP. While this IT project manager was certainly experienced in the technology implementation of the platform, it was observed that the clinical workflow elements were not discussed or given as much focus as was possible. After implementation, this was highlighted through some gaps in knowledge from the staff and leadership, and this became a major focus for the implementation guide. Examples of these workflows include knowledge of new emergency code workflows with the new technology, staff knowing the calling process for who was and was not going to be working on the new platform, and processes in the departments for managing downtimes in the new technology.

- Opportunities observed in the training at KP-MCX were key to the information that was placed in the implementation guide. Training was focused solely on the hardware (the devices) and the software (VCS) and was provided by the vendor. There was no training to the new processes and workflows that were coming with the change in the clinical communication methodologies in the organization, and this led to negative outcomes post go-live.

- Issues post go-live in KP-MCX were one of the most valuable sources of information for inclusion. The post go-live data collection at KP-MCX clearly demonstrated issues and dissatisfaction with the technology. These data were prioritized for use in the implementation guide, as it provided pitfalls to avoid in future implementations. 
- Types of technology used in other organizations were also observed for inclusion. The project lead drew on personal experiences as a clinical and informatics leader to create the structure of the implementation guide. Bringing experiences from other organizations helped to show multiple perspectives to KP and inform the guide.

- Unexpected feedback from the live sites after the KP-MCX implementation proved useful for the guide within a COVID context. No more sites were planned to go-live with the platform after KP-MCX's implementation; however, with the COVID pandemic, Vocera badges were distributed (without the complete platform) for isolation room communication. Interviews with nurse leaders from these facilities provided useful information to include in the guide, especially for COVID workflows.

- Finally, once a draft of the guide was finished, feedback was sought from nursing and informatics leaders in the live and soon-to-be-live sites, as well as from the IT project manager and leadership on the project. This information was then added to the guide.

All the data points above provided the information necessary to assure the information accurately represented a guide that could be assessed by key stakeholders for its usefulness.

\section{Analysis}

No software was utilized in the analysis of the implementation as the data were manually analyzed by the project lead, as well as by the organization's research department staff . Since there were two interventions in this project, the analysis is described in two sections below: one for the pre- and post-data collection and one for the implementation guide.

\section{Pre- and Post-Implementation Data}


As described, data collection for this project utilized mixed methods that included interviews, focus groups, direct observations, and online surveys; therefore, both quantitative and qualitative methods were used for data analysis.

Interviews. During the interviews, staff were asked to rate pre-set statements on a scale of 1 to10. An example statement was, “The communication tool I am provided supports effective and efficient care delivery." Because of the numerical rating of these questions, a quantitative assessment was able to be determined for these questions. However, the interviews also yielded rich qualitative statements from the participants, and the data were analyzed and coded, and a thematic analysis was created. This analysis followed Miles and Huberman's (1994) framework (as cited in Moule \& Goodman, 2014) of coding data, so it can be reduced, displayed, and conclusions can be drawn and verified.

Focus groups. No Likert-type questions were given in the focus groups, so no quantitative data were obtained. The qualitative data were analyzed, coded, and placed into themes using the same process as mentioned previously.

Direct observations. The shadowing portion of the data collection helped to validate the data collected during the interviews and focus groups and gave further insight into the unique needs and challenges faced on a day-to-day basis by the participating clinicians. Qualitative thematic analysis was conducted on the comments and observations during these shadowing periods, and at the suggestion of the frontline staff, day and evening shifts were observed in nine different departments, yielding different data for the different shifts.

Survey. An online, anonymous survey was designed to elicit both quantitative and qualitative data. Quantitative methods were utilized to measure the online survey and collection 
of metric data pre- and post-implementation, which included determining if certain metrics improved with the implementation.

\section{Implementation Guide}

The second part of the project was to create a toolkit or guide for future implementations. As mentioned, leadership at the six facilities that are already live on this platform had stated that they found the go-lives very IT-driven. The PICOT question for the second part of this project asked, for inpatient nurse leaders, would a preparation and implementation guide (compared to no guide) positively impact the implementation of a smartphone communication platform in their hospitals ? Klein and Sorra's (1996) implementation model states that how well an innovation is adopted is a result of the organization's climate and the organization's employees' perceptions of the fit of the innovation within the organization's values. Previous implementations of this communication technology were focused largely on the functionality of the technology and the tasks necessary for go-live. The guide's aim was to add elements to the technical guide that included introducing the rationale and clinical ROI of the technology, discussing organizational culture, and considering the clinicians' perceptions of the fit in their organization. The guide was written using information from other KP live sites in Southern California, as well as detailed information learned from the KP-MCX go-live. The guide sections include background to the project, descriptions of the technology, and detailed step-by-step instructions for implementation leads on the different stages of the project they will be leading, including sample presentations to executive leadership, timelines, details of the workgroup duties, expected workflow changes, and recommendations on training, go-live, and post go-live support.

The first draft of the guide was prepared and sent to members of the IT team for their input and suggestions regarding the technical elements of the guide. After completing the second 
draft, it was sent to the directors of Clinical Informatics in the Southern California and Northwest KP regions. They have been overseeing the implementations in the six sites in Southern California and two in Oregon, and they provided valuable input on structure, content and addition information utilizing their subject matter expertise in the area of nursing leadership and informatics.

To analyze its effectiveness, the guide was sent to nurse leaders and clinical informaticists in the six live Southern California sites to determine if it covered all elements from their go-live, to see if they perceived the guide would have been useful in their go-lives, and to ask if there were any items missing. It was also sent to key nurse leaders and clinical informaticists in the non-live sites to determine if they felt the content of the guide would be useful to them, if they had any input into the guide, and if there were unanswered questions they may have after reading the guide. The guide was accompanied by a six-question survey tool with quantitative and qualitative answers (see Appendix T for survey questions).

When asking the nursing and informatics leaders for input into the guide, one variation to be accounted for was the different processes in the different regions (Northern California, Southern California, and the Northwest regions of KP). Within these different regions are different philosophies, cultures, nomenclatures, union environments, and rollout methodologies. Each time feedback was received, a new iteration of the guide was completed, until it had all the feedback incorporated. The guide was also streamlined along the way to ensure it was truly a usable document for the facility leads in the future.

\section{Ethical Considerations}


The focus of this project was to determine if a clinical communication platform can improve staff efficiency and the quality of care provided. To do this, staff were interviewed and assessed; therefore, potentially making staff human subjects from a research perspective. As such, there was an ethical responsibility to ensure these participants were protected from harm and discomfort, they were not exploited in any way, they had the right to be treated fairly with dignity and privacy, and they had full disclosure of all events that may occur during the project (Polit \& Beck, 2018). With that in mind, an application was placed with the health system's IRB to determine if this project fell under the umbrella of human subject research. The IRB determined this was not human subject research and designated the work as a performance improvement project (see Appendix V). Permission was also granted from the project lead's health systemwide direct nurse leader for the project to be conducted (see Appendix W).

On October 14, 2019, the University of San Francisco's (USF) DNP department determined that this project met the guidelines for an evidence-based change of practice project, as outlined in the DNP project checklist (statement of determination) and was approved as nonresearch (see Appendix X for the USF Non-Research Determination Form). There were no identifiable issues or conflicts of interest noted for this project. Finally, in creating this project, the USF Jesuit values were taken into consideration, as the USF's value statements describe their respect "for every individual's intellectual, physical, and spiritual health and autonomy" (USF, 2019, para. 2). 
Even though the project did not fall under the purview of the IRB, there was still a responsibility on the part of the project lead to ensure all staff felt safe and protected as they were interviewed and observed in their place of work. All staff who participated in any of the activities for this project were given written permission forms and were told that all information reported from the project would be anonymized. They were assured that no names were associated with their information, information directly attributed to them would not be reported to their managers, and their participation was voluntary. This aligns directly with the Provision 3.2 of the American Nurses Association's (2014) Code of Ethics, which confirms that all research must be approved by the institution's IRB and that individuals have the right to choose whether to participate in the research or not participate. 


\section{Section IV: Results}

The project was conducted in two parts; therefore, the results will be presented in two separate sections. Additional unexpected results due to COVID-19 are also included.

\section{Pre- and Post-Intervention Data Collection}

For this study, the formal pre-go-live studies were done two weeks before go-live and five weeks post go-live. For the question, "Does the introduction of smartphone communication strategies (compared to no smartphones) have a positive effect on productivity/efficiency, quality of care, and communication in a large hospital system within a six-month period post go-live?" the immediate results did not support the evidence-based question. There is evidence in the months following (during COVID-19) that productivity, quality of care, and communication did improve with the implementation of parts of the technology.

As a high-level overview, the qualitative data collected in the immediate period postimplementation for KP-MCX demonstrated negative results, in general, with only a small number of positive themes noted. Overall, the results established that staff found secure messaging very useful and that the battery life of the devices improved from pre-implementation. However, the reliability of the device was severely compromised by poor Wi-Fi connectivity, and the overall feedback from staff post-implementation was that the technology did not meet end-user needs. While an extensive Wi-Fi assessment had been conducted prior to go-live, changes made by an IT team unaware of the IHC project caused reliability issues for the clinical users after go-live. Because of that, in many cases, they were still carrying their old analog phones and were challenged with integrating the new devices into their workflows. Apart from the reliability issues, feedback from staff included that the devices were clunky, heavy, the clip was not sturdy, and the interface was not easy to use, including the keyboard, size of the screen, 
and findability of features on the device. From a training perspective, staff reported that the new communication workflows were not well understood, and nurse leaders stated that the transition plan and operations strategy was not available for their review. Finally, the platform did not align with user expectations or the mental model of what a communication device should be, for example, one staff member said, “It's a phone, but you can’t dial a number."

Interviews. Seventeen one-to-one interviews were conducted pre-implementation and 14 were done post-implementation. RNs made up the majority of participants pre-implementation, with ward clerks, physicians, and pharmacists making up the remaining participants. Postimplementation, RNs were again the largest group, and the remaining participants were physicians, child life specialists, ward clerks, operators, and pharmacists. The interviews were both quantitative and qualitative in nature, and the participants were asked the same set of questions on a scale of 1 to 10 pre- and post-implementation. Quantitatively, the interview results demonstrated two of the eight questions showed an improvement (better maintenance and reliability) post-implementation, but eight questions showed a reduction in satisfaction with clinical communication at their facility. Table 1 displays the results, with the intended scores to denote $<7.0$ being a detractor, 7.0 to 9.0 being neutral, and $>9.0$ a promoter. 
Table 1

Pre and Post Interview Question Results

\begin{tabular}{lcc}
\hline Statement & $\begin{array}{c}\text { Pre- } \\
\text { Implementation }\end{array}$ & $\begin{array}{c}\text { Post- } \\
\text { Implementation }\end{array}$ \\
\hline $\begin{array}{l}\text { The communication tools I am provided are maintenance } \\
\text { free. }\end{array}$ & 6.8 & 7.5 \\
$\begin{array}{l}\text { The communication tools I am provided are reliable. } \\
\text { The communication tools I am provided support effective } \\
\text { and efficient care delivery. }\end{array}$ & 6.7 & 7.0 \\
$\begin{array}{l}\text { The communication tools I am provided support patient } \\
\text { or family member satisfaction. }\end{array}$ & 7.9 & 6.6 \\
$\begin{array}{l}\text { The communication tools I am provided support patient } \\
\text { safety. }\end{array}$ & 7.9 & 6.3 \\
$\begin{array}{l}\text { The communication tools I am provided support quality } \\
\text { communications. }\end{array}$ & 7.7 & 7.5 \\
$\begin{array}{l}\text { The communication tools I am provided result in } \\
\text { efficient turnaround times. }\end{array}$ & 7.6 & 6.9 \\
$\begin{array}{l}\text { The communication tools I am provided support care } \\
\text { team engagement. }\end{array}$ & 8.4 & 7.5 \\
\hline
\end{tabular}

Qualitative results from the interviews were also mixed. Staff were given either a TC51 smart device or a Vocera hands-free badge, depending on their unit, and reported some successes, but mostly frustration with the new technology (see Appendix Y for a full synopsis of the pre- and post-implementation data collection).

Focus groups. The goal of the five pre and post focus groups were to facilitate the gathering of information, with the added advantage of the group bouncing ideas off each other. The data collected in the focus groups mirrored the sentiments of the one-to-one interviews which indicated a level of dissatisfaction with the technology, yet because of the focus group format, the potential of the technology was highlighted by staff once the connection issues were resolved. Difficulties using the badge genie (the central number) and the form factor of the device (size, weight, multiple steps to make a call) were also themes noted in the focus groups. (see Appendix Y). 
Direct observations/shadowing. The data collection pre- and post-implementation included time spent with each group while they did their work in their departments. While this was a limited amount of time, the 12 observations before implementation and 11 after implementation were useful in that they validated the data collected during the interviews and focus groups, as well as learning other key insights into the unique needs and challenges of each team and their communication methodologies. The difficulties noted in the interviews and focus groups were seen first had during the post-implementation shadowing, yet successful use of the technology was observed, and positive comments were elicited from clinicians on the units.

Online survey. The goal of the survey was to gain high-level, quantifiable insights into the pulse of the organization in an anonymous manner without the researchers present. Twentysix surveys were completed pre-implementation and 80 surveys were completed postimplementation. Flyers were posted with details of the survey and since it was open to all staff before and after the go-live, it is unknown what percentage of the same staff completed both the pre and post survey. Staff were asked to rate if they agreed or disagreed with statements in the survey, and all results at the agree or strongly agree level were correlated. Across the board on each question, the scores were lower post-implementation (see Table 2) 
Table 2

Pre and Post Online Survey Question Results

\begin{tabular}{|c|c|c|}
\hline Statement & $\begin{array}{l}\text { \% Pre- } \\
\text { Implementation } \\
(\mathrm{n}=26)\end{array}$ & $\begin{array}{l}\% \text { Post- } \\
\text { Implementation } \\
\quad(n=80)\end{array}$ \\
\hline $\begin{array}{l}\text { I am confident the tools provided to me support the clinical } \\
\text { communications I need for care delivery. }\end{array}$ & 88 & 45 \\
\hline $\begin{array}{l}\text { I find the tools provided to me support high-quality clinical } \\
\text { communications. }\end{array}$ & 62 & 43 \\
\hline $\begin{array}{l}\text { I find the tools provided to me for clinical communications are } \\
\text { easy to use. }\end{array}$ & 81 & 33 \\
\hline $\begin{array}{l}\text { I am confident the tools provided to me for clinical } \\
\text { communications are reliable. }\end{array}$ & 50 & 28 \\
\hline $\begin{array}{l}\text { I received adequate training on the tools I use for clinical } \\
\text { communications. }\end{array}$ & 58 & 51 \\
\hline $\begin{array}{l}\text { The tools I am provided for clinical communications make it } \\
\text { possible for me to successfully complete all necessary } \\
\text { communications tasks for care delivery. }\end{array}$ & 81 & 28 \\
\hline $\begin{array}{l}\text { The tools I am provided for clinical communications support care } \\
\text { team engagement. }\end{array}$ & 62 & 30 \\
\hline $\begin{array}{l}\text { The tools I am provided for clinical communications support fast } \\
\text { turnaround times. }\end{array}$ & 62 & 26 \\
\hline $\begin{array}{l}\text { I felt very confident using the tools I am provided for clinical } \\
\text { communications. }\end{array}$ & 85 & 33 \\
\hline $\begin{array}{l}\text { I needed to learn a lot of things before I could get going with the } \\
\text { tools for clinical communications I use today. }\end{array}$ & 46 & 49 \\
\hline $\begin{array}{l}\text { The tools I am provided today for clinical communications } \\
\text { require little to no maintenance. }\end{array}$ & 54 & 35 \\
\hline $\begin{array}{l}\text { The tools I am provided today for clinical communications } \\
\text { support high patient/caregiver satisfaction. }\end{array}$ & 42 & 31 \\
\hline $\begin{array}{l}\text { The tools I am provided today for clinical communications } \\
\text { support patient safety. }\end{array}$ & 42 & 16 \\
\hline
\end{tabular}

The survey also included the opportunity for staff to add comments to open-ended questions, again with some positives, but most displaying negative findings (see Appendix Y).

\section{Results from Other Hospitals within the System Due to COVID-19}

While not a formal part of the data collection, this project evolved alongside the evolution of the COVID-19 pandemic in the United States in March 2020. Many hospitals within the health system sought technological solutions to the communication difficulties that the 
pandemic brought about. In interviews with nurse leaders who had quickly implemented and utilized the IHC technology in Southern California because of pandemic workflows, the results were overwhelmingly positive. Managers reported the secure messaging functionality was popular, as the charge nurse was outside the isolation units and the staff inside could text to communicate with them. Device earpieces worked well when staff had donned their Powered Air Purifying Respirator (PAPRs); although, some staff did not like the feeling of the bulky earpiece. While no formal study was done around the reasons for the success of the technology in this time was done, it could be supposed that in the pandemic situation, where severe pressure was placed on existing processes and workflows, any solution that could ease the communication burden was warmly welcomed. One manager stated, "Vocera has been extremely useful during COVID19: a 10 on a scale of $1-10$," and another stated, "The command center used it all the time to send group broadcasts during the height of COVID." Finally, the 'role' and 'group' messaging functions were particularly useful with roles/groups set up for each of the new communication workflows needed for the pandemic. These included roles/groups for staff who were assisting clinicians into and out of their personal protective equipment (med-surg/ICU donner and medsurg/ICU doffer) as well as roles set up for a family update nurse and groups for the OR intubation team, the COVID labor pool, COVID-19 questions, and command center call tree groups.

\section{Implementation Guide Intervention}

Feedback from the implementation guide was intended to be collected both quantitatively through an online survey, and qualitatively through comments inserted directly into the guide or given verbally. Before feedback was sought from end-users, the two informatics leaders from other KP regions, as well as the members of the IT project team who had previously been leading the implementation reviewed and gave input into the guide, and five inputs were received. Four 
chief nurse executives (CNEs), four senior IT leaders, and 14 nursing informatics managers or directors were then asked for their input. Participants had either implemented the platform already or were going to be implementing it soon. Input was slow to be received, even with reminders and prompting. The online quantitative survey was only completed by one respondent and was therefore abandoned. Participants preferred to write their feedback directly into an email or onto the guide or called personally to give verbatim comments. These comments were then collected, analyzed, and added to the guide in the appropriate sections.

IT leadership who gave feedback ensured that all elements of the technologies were represented appropriately in the guide. They felt the comparison of old and new technologies included in the guide was not necessary; yet, the feedback from the CNEs was that this comparison was very helpful, "It tells the story nicely about features a nurse leader can tell their staff that they now have access to", therefore it was left in the document. The only CNE who gave feedback into the document requested that a draft timeline be included to spell out "when should I start work on this project." While a high-level timeline had been in the original document, a more detailed one was added that focused on the role of the facility lead. She also stated she was confused between the core group and workgroups, so this was clarified in the guide. One key element she asked to be included was to ensure that the facility lead was the actual leader of the sessions where the new workflows were determined. As overall feedback, she stated, "It's long, but for a nurse leader who is a novice in these clinical communication technologies, this is an extremely informative guide." Finally, she asked if there was a pocket guide that will detail a summary of the different hardware and software, and it was explained that the vendor provides this type of pocket guide. 
The remaining feedback was received from informatics managers or directors in the region that will be implementing the technology in the near future. Specific recommendations that had a positive impact on the guide included:

- Adding details of when and how the old technology will be removed from use, who is responsible for this collection, and how the old technology will be disposed of in an environmentally friendly manner.

- Since the nursing element is rolling out first, ensuring there is a solid support structure post-implementation that prevents the $24 / 7$ responsibility falling to nursing at the facility, especially when non-nursing departments are going live later.

- Providing the criteria for determining which departments will get which technology (smart device vs hands free badge).

- Detailing specific downtime procedures for the technology as well as adding a troubleshooting section for post go-live.

- Making the ongoing governance section more robust, including the process locally and regionally for larger issues like alarm management on the device. This includes governance of new technologies that might be requested in the future to ensure they are compatible with the IECCS devices.

- Placing a higher emphasis on the involvement of IT support, telephony and the telecommunications systems in the preparation for go-live.

- Adding videos that demonstrated the technology for those more visual learners and highlighting more the need for training of departments without the technology (i.e. how they will communicate with the live departments). 
- Providing templated policies and procedures to the guide (these will be developed for the regions and will be added for all future go-lives after the upcoming regional pilot for 22 hospitals).

- Increasing the details around key benefits and purpose of the guide in the executive summary.

As each piece of feedback was received, the guide was updated, and continued feedback was sought with each iteration. Verbatim comments from the reviewers of the guide were all positive, with two leaders stating it was "impressive work" and others stating it "looked amazing", was "very organized", was “wonderful" and "I love it". No negative feedback was received and the constructive additions above were added as they were received. 


\section{Section V: Discussion}

\section{Summary}

The aim of this project was to see if a clinical communication technology implementation improved productivity/efficiency, quality of care, and communication in a large hospital system and if an implementation guide would help with future implementations. With six out of eight post-implementation interview questions demonstrating a reduction in satisfaction and 13 out of 13 post online survey questions also demonstrating a reduction in satisfaction, the results clearly demonstrated that staff did not feel the technology improved care in their departments. Yet, the implementation provided valuable insights about the pitfalls of such go-lives, and these learnings are clinically significant in that they were utilized to avoid similar issues in future implementations. These learnings also provided valuable data for the preparation of an implementation guide, which nurse leaders clearly believe will have a positive impact on the implementation of a smartphone communication platform in their hospitals in the future.

A key finding of this project was that a clinical communication platform is only as good as the wireless system on which it operates. If that wireless system is not operating successfully, the communication platform will be seen as not functioning and, therefore, will not be useful to staff. However, with the evolution of the needs of the organization during the COVID pandemic, the technology was also implemented in other hospitals within the system. In those hospitals, the findings were impressive, so much so that it could be said that the objective of the project was reached in those organizations. Also, the failure of the first intervention contributed most importantly to the success of the second intervention, which was the implementation guide. It is projected that the learnings from the KP-MCX implementation will provide the valuable insight needed for the success of 22 further implementations in the organization in the near future. The 
dissemination of the implementation guide will be done approximately three months before each of these facilities go live, which will give the facility leads time to absorb the information and operationalize the plan. Based on the feedback from reviewers of the implementation guide, it is expected that this will improve future go-lives in the organization.

The implications for advanced nursing practice of the project is that there is now a valid and clinically-focused guide that can help nurse leaders implement a communication system efficiently, "providing the right information to support problem-solving and decision-making and helping to establish and maintain alignment among business strategy, project strategy, and project execution outcomes" (Martinelli \& Milosevic, 2016, p. 3). The guide utilizes the concepts from Michel-Verkerke and Spil's (2013) USE IT-adoption-model, which states there are four determinants to the success of the adoption of IS systems: relevance, requirements, resources, and resistance.

\section{Interpretation}

The evidence in the literature outside of KP clearly demonstrates the benefits of implementing technological solutions for clinical communication (Agarwal et al., 2010; Bautista et al., 2018; Breslin et al., 2004; Brooks, 2018; Brown-Manhertz, 2017; Chatterjee et al., 2009; Devrim et al., 2019; De Grood et al., 2013; Jeon \& Park, 2015; Machon et al., 2020, Martin et al., 2019; Mehrzad \& Barza, 2015; Menon \& Rivett, 2019; Mickan et al., 2014; Motulsky et al., 2017; Patel et al., 2016; Runyon, 2018; VanDusen, 2017; Vermeir et al., 2015; Whitlow et al., 2014). The benefits of improving communication are obvious; yet, if the implementation process has significant issues, the benefit is not realized, as in the case of KP-MCX. This occurred due to a number of reasons, including poor connectivity, which the end-users correlated to "Vocera not working"; a lack of training for and understanding of the new communication expectations and 
methodologies; a technology-focused than clinically-focused implementation; and a lack of understanding regarding the paradigm shift that was about to occur in the whole organization.

While there was no statistically significant improvement in communication after the implementation, there was a clinical significance to the implementation in KP-MCX. Lefort (as cited in Ranganathan, Pramesh, \& Buyse, 2015) stated that clinical significance "should reflect the extent of change, whether the change makes a real difference to subject lives, how long the effects last, consumer acceptability, cost-effectiveness, and ease of implementation” (p. 169). This is particularly pertinent in this study. The clinical significance of the findings at KP-MCX are the learnings that can be taken from this implementation and applied to future installations of this technology. The impact at KP-MCX to the staff was significant, with negative feelings and distrust of the new technology. Yet, the impact to the organizational system was positive, as the learnings from KP-MCX can now be taken to prevent the same issues in the next facilities.

Post-implementation, there were significant IT costs to the remediation at KP-MCX, as well as the cultural and emotional cost of a failed implementation, especially in departments that had to revert to their previous analog communication methods. This type of failure is devastating to a project, and there will be a substantial benefit to avoiding and managing these potential risks in the next implementations. By identifying the risks and providing mitigation strategies for these issues in the implementation guide, the organization can then pre-empt problems before they occur and manage them proactively as recommended by Martinelli \& Milosevic (2016, p. 377).

Because the wealth of knowledge in the field exists from previously successful implementations, it was assumed that this implementation would improve productivity/ efficiency, quality of care, and communication. While this was not realized in KP-MCX, it was realized in other KP organizations, and enough data were captured to ensure success as the 
technology is spread in future implementations. The goal of the implementation guide is that it will provide the tools necessary to spread this technology in a positive manner and sustain the improvements that other KP sites have noted with its implementation.

Challenges that were noted at KP-MCX, including the statement, "We don't know how to contact physicians, some want calls, some don't, a process for escalation is not defined," should be mitigated in the future if facility leads follow the steps in the guide, and examples like this should be thought about in advance in order to help education departments focus their efforts in staff training for the new technology. The training gaps identified in the KP-MCX implementation provide a rich source of detailed information for the next facilities to include in their curriculum. Learning from these gaps should help trainers include role- and workflowbased training scenarios that will help adult learners grasp the concepts of the new technological workflows. These include not only the technology and how it works, but also expectations (i.e., it is not a "phone," dialing a number is not the same as before) and workflows associated with the new technology. Finally, the next facilities to implement the technology need to have strong governance processes in place in case there are major issues, like those that occurred at KP-MCX when connectivity was poor in the immediate days post go-live.

\section{Limitations}

The intention of having multiple methodologies for assessing the implementation was to prevent bias associated with only one data collection methodology. As evidence in the literature had shown the efficacy of this technology in other organizations, the project lead admits there was a certain amount of bias with the expectation that this was going to be successful. This was mitigated by frank and open conversation with the other project members and a realization that this could occur. Every effort was made to host interviews and focus groups with no bias 
demonstrated to staff at the facility. Another potential limitation was that there was no guarantee that same people were interviewed/surveyed pre- and post-implementation, and this means a true comparison of the same individual's feelings about the technology could not be conducted. This was due to the limited availability of staff in both phases and the random allocation of the survey tool via posters encouraging completion or the anonymous survey. On review, the addition of a simple survey question: "did you complete a pre-implementation survey" would have mitigated this lack of visibility into the issue.

The major limitation of the project was the skewing of the data due to the poor Wi-Fi capabilities in the facility post go-live. Connectivity issues directly affected the technology performance, with staff relating the poor performance to the technology and not the Wi-Fi. There is no way to effectively determine if the new technology was actually meeting their needs, because the technology did not work effectively due to connectivity issues. While a technology assessment had been done in the week prior to deployment, two different IT departments were working on different projects and changes made by one department was the ultimate cause of the poor connectivity for the other department post go-live. This will now be mitigated by instituting an IT change freeze in the week(s) before go-live in future implementations.

These limitations could be reassessed by conducting another staff survey; however, in subsequent interviews with nurse leaders at KP-MCX, while the Wi-Fi connectivity issues have improved, staffs' relationship with the new technology continues to be tenuous, and a return visit for further data collection was not advised by nursing leadership.

\section{Conclusions}

This project has demonstrated that care teams are complex organisms, and care team communications require easy, quick, and efficient access to others. The barriers faced in this 
implementation caused multiple issues and ultimate dissatisfaction with the technology that was supposed to assist the staff. One staff member summed up the implementation quite effectively; "I think it has the potential to be more efficient and more effective in making patient care happen or addressing issues more quickly. I think it's just everyone needs to be on the same page about being good about tech, like assigning yourself to a room or a role, to be checking your messages and responding to them" (KP-MCX Pharmacist, personal communication, November 5, 2019)

An implementation guide that facilitates consistent processes will be instrumental in the success of future go-lives. Organizations need to ensure rigorous testing of Wi-Fi systems before go-live, strong preparation of facility leads, and detailed training of staff that focuses on the technology plus the workflows and new communication systems. Engaging potential end-users in understanding the facility's current workflows, technologies, and the unique needs of different departments will be vital to the success of future go-lives. A solid process in the form of a grid for end-users, in which the methodologies used to contact people post-implementation are clearly detailed, is vital. This should include how to contact various user types, how to handle escalations, and how to get questions answered quickly. Leadership needs to send out regular messages in the weeks before go-live with details concerning what is changing and what is coming next. Roadshows, FAQs (frequently asked questions), and ongoing communications will provide effective ways to demonstrate the different journeys that end-users will be taking postimplementation and the key benefits of the new technology. Standardized policies, procedures, and processes (including log in/roll assignment, communication etiquette, and shift-to-shift handoff expectations) should be in place before go-live for all staff to follow, and this should be included in the contextual role-based training that is provided for all staff. Strong on-unit support 
staff or out-of-the-count super-users available during and after go-live will help bridge any gaps missed in training, and a strong governance process pre and post go-live will help by providing a robust process to escalate immediate concerns where "showstopper conditions" might require top manager intervention (Martinelli and Milosevic, 2016, p. 331) as well as bring the nursing voice to the leadership table to guide the organization in the implementation (Machon, Knighten, \& Sohal, 2020)

While this implementation did not meet the first PICOT question at KP-MCX, it was still successful in other facilities for their COVID workflows. It can also be considered successful as it informed the content for the second intervention, the implementation guide, which will prevent the same occurrences happening in future implementations. 


\section{Section VI: Other Information}

\section{Funding}

This project was instituted to bring the clinical perspective to the IHC business case and to present the clinical ROI for a unified communication system at KP. Subsequently, $\$ 140,000$ of funding was allocated to pay for the project lead's CBP 0.5 FTE wage over a nine-month period in order to correlate the evidence for the business case, including travel and expenses. With KPMCX identified as going live with this technology, it was decided that the CBP's 0.5 FTE funding could also be utilized to collect the pre- and post-implementation data. In the five months prior to the data collection, the CBP had utilized only approximately $35 \%$ of the monthly funds allocated, and the project's executive sponsors agreed that the remaining funds could be re-allocated to contract with the organization's non-clinical research team and to engage an RN project assistant to help with data collection and analysis. Over a nine-month period, the budget had not been fully utilized, and a $\$ 22,000$ positive variance is still in place. 


\section{Section VII: References}

Agarwal, R., Sands, D., \& Schneider, J. (2010). Quantifying the economic impact of communication inefficiencies in U.S. hospitals. Journal of Healthcare Management, 55(4), 265-281. Retrieved from https://pubmed.ncbi.nlm.nih.gov/20812527/

Aiken, L., Clarke, S., Sloane, D., Sochalski, J., \& Silber, J. (2002). Hospital nurse staffing and patient mortality, nurse burnout, and job dissatisfaction. Journal of the American Medical Association, 288(16), 1987-1993. doi:10.1001/jama.288.16.1987

Al Thomairy, N., Mummaneni, M., Alsalamah, S., Moussa, N., \& Coustasse, A. (2015). Use of smartphones in hospitals. Health Care Manager, 34(4), 297-307.

doi:10.1097/HCM.0000000000000080

American Association of Colleges of Nursing. (2006). The essentials of doctoral education for advanced nursing practice. Retrieved from https://www.aacnnursing.org/DNP/DNPEssentials

American Nurses Association. (2014). Code of ethics. Retrieved from https://www.nursingworld.org/practice-policy/nursing-excellence/ethics/code-of-ethicsfor-nurses/

Astarcioglu, M., Sen, T., Kilit, C., Durmus, H. I., Gozubuyuk, G., Kalcik, M., \& Zencirkiran, A. (2015). Time-to-reperfusion in STEMI undergoing interhospital transfer using smartphone and WhatsApp messenger. American Journal of Emergency Medicine, 33(10), 1382-1384. doi:10.1016/j.ajem.2015.07.029

Bautista, R., Rosenthal, S., Lin, T., \& Theng, Y. (2018). Predictors and outcomes of nurses use of smartphones for work purposes. Computers in Human Behavior, 84, 360-374. doi:10.1016/j.chb.2018.03.008 
Bodenheimer, T., \& Sinsky C. (2014). From triple to quadruple aim: Care of the patient requires care of the provider. Annals of Family Medicine, 12(6), 573-576. doi:10.1370/afm.1713

Boettcher, P. A., Hunter, R. B., \& McGonagle, P. (2019). Using Lean principles of standard work to improve clinical nursing performance. Nursing Economic\$, 37(3), 152-163. Retrieved from https://search.proquest.com/docview/2243308672?pqorigsite $=$ gscholar $\&$ fromopenview $=$ true

Breslin, S., Greskovich, W., \& Turisco, F. (2004). Wireless technology improves nursing workflow and communications. Computers, Informatics, Nursing, 22(5), 275-281. doi:10.1097/00024665-200409000-00007

Brooks, B. (2018). Creating an integrated healthcare ecosystem through mobile communication technology. TigerConnect. Retrieved from https://www.tigerconnect.com/newsroom/creating-an-integrated-healthcare-ecosystemthrough-mobile-communication-technology/

Brown-Manhertz, D. (2017). Using smartphones to improve interdisciplinary collaboration. Nurse Practitioner, 42(4), 1-5. doi:10.1097/01.NPR.0000513341.77191.03

Chari, A., \& Gane, S. (2018). Instant messaging applications in healthcare: Are we harnessing their potential? BMJ Innovations, 4, 5-8. doi:10.1136/bmjinnov-2017-000197

Chatterjee, S., Chakraborty, S., Sarker, S., Sarker, S., \& Lau, F. (2009). Examining the success factors for mobile work in healthcare: A deductive study. Decision Support Systems, 46(3), 620-633. doi:10.1016/j.dss.2008.11.003 
Chen, J., Park, Y., \& Putzer, G. (2010). An examination of the components that increase acceptance of smartphones among healthcare professionals. Electronic Journal of Health Informatics, 5(2), e16. Retrieved from https://www.researchgate.net/publication/50922587_An_Examination_of_the_Componen ts_that_Increase_Acceptance_of_Smartphones_among_Healthcare_Professionals

De Grood, J., Wallace, J., Friesen, S., White, D., Gilmour, J., \& Lemaire, J. (2012). Evaluation of a hands-free communication device in an acute care setting: a study of healthcare providers' perceptions of its performance. Computers, Informatics, Nursing, 30(3), 148156. doi:10.1097/ncn.0b013e31823eb62c

Devrim, İ., Düzgöl, M., Kara, A., Çağlar, İ., Devrim, F., Bayram, N., \& Apa, H. (2019). Reliability and accuracy of smartphones for paediatric infectious disease consultations for children with rash in the paediatric emergency department. BMC Pediatrics, 19(1), 1-5. doi:10.1186/s12887-019-1416-8

Doyle, G., Garrett, B., \& Currie, L. (2014). Integrating mobile devices into nursing curricula: Opportunities for implementation using Rogers' diffusion of innovation model. Nurse Education Today, 34(5), 775-782. doi:10.1016/j.nedt.2013.10.021

Drews, F., Zadra, J., \& Gleed J. (2018). Electronic health record on the go: Device form factor and Fitts' law. International Journal of Medical Informatics, 111, 37-44. doi:10.1016/j.ijmedinf.2017.12.010

Freundlich, R., Freundlich, K., \& Drolet, B. (2018). Pagers, smartphones, and HIPAA: Finding the best solution for electronic communication of protected health information. Journal of Medical Systems, 42(1), 1. doi:10.1007/s10916-017-0870-9 
Gill, P., Kamath, A., \& Gill, T. (2012). Distraction: An assessment of smartphone usage in health care work settings. Risk Management and Healthcare Policy, 5, 105-114. doi:10.2147/RMHP.S34813

Health Information and Management Systems Society Analytics. (2018). Research findings: Frequent interruptions distract clinicians from patient care, contribute to stress and burnout. Retrieved from https://www.vocera.com/public/pdf/Vocera_HIMSS_Analytics_HIMSS18-SurveyReport.pdf

Hearon, S. (2018, May 7). Major health partners improves clinical workflows and patient satisfaction with Vocera Solution. Retrieved from https://www.vocera.com/pressrelease/major-health-partners-improves-clinical-workflows-and-patient-satisfactionvocera

Higgins, L. W., Shovel, J. A., Bilderback, A. L., Lorenz, H. L., Martin, S. C., Rogers, D. J., \& Minnier, T. E. (2017). Hospital nurses' work activity in a technology-rich environment: A triangulated quality improvement assessment. Journal of Nursing Care Quality, 32(3), 208-217. doi:10.1097/NCQ.0000000000000237

Hoonakker, P., Carayon, P., \& Cartmill, R. (2017). The impact of secure messaging on workflow in primary care: Results of a multiple-case, multiple-method study. International Journal of Medical Informatics, 100, 63-76. doi:10.1016/j.ijmedinf.2017.01.004

Hopkins, P. (2018). Fundamentals of risk management: Understanding, evaluating and implementing effective risk management (5th ed.) London: Kogan Page.

Hughes-Driscolla, C., Gurmub, S., Azeem, A., \& El Metwally, D. (2019). Implementation of smartphones to facilitate in-hospital telephone communication: Challenges, successes and 
lessons from a neonatal intensive care unit. Healthcare. Sep;7(3):100331.

doi:10.1016/j.hjdsi.2018.07.001

Institute of Healthcare Improvement. (2019). Run chart tool. Retrieved from http://www.ihi.org/resources/Pages/Tools/RunChart.aspx

Jeon, E., \& Park. H. (2015). Nursing intervention using smartphone technologies: A systematic review and meta-analysis. Studies in Health Technology \& Informatics, 210, 321-325. doi:10.3233/978-1-61499-512-8-321

Johns Hopkins Nursing. (2017a). Johns Hopkins nursing evidence-based practice, Appendix E: Research evidence appraisal tool. Retrieved from https://www.ijhneducation.org/node/1535/done?sid=53091\&token=c5693353a7fea4473a7e77aa4660f9a2

Johns Hopkins Nursing. (2017b)._Johns Hopkins nursing evidence-based practice, Appendix F: Non-research evidence appraisal tool. Retrieved from https://www.hopkinsmedicine.org/evidence-basedpractice/_docs/appendix_f_nonresearch_evidence_appraisal_tool.pdf

Johnson, A., Hajj, S., Perret, J., Caffery, T., Jones, G., \& Musso, M. (2015). Smartphones in medicine: Emerging practices in an academic medical center. Journal of Medical Systems, 39(1), 1-6. doi:10.1007/s10916-014-0164-4

Joint Commission. (2016). Sentinel event statistics released for 2015. Retrieved from http://info.jcrinc.com/rs/494-MTZ-066/images/Sentinel39.pdf

Joseph, B., Pandit, V., Khreiss, M., Aziz, H., Kulvatunyou, N., Tang, A., ... Rhee, P. (2013). Improving communication in level 1 trauma centers: Replacing pagers with smartphones. Telemedicine e-Health, 19(3), 150-154. doi:10.1089/tmj.2012.0114 
Kaufman, D. (2005). Using project management methodology to plan and track inpatient care. Joint Commission Journal on Quality \& Patient Safety, 31(8), 463-468. doi:10.1016/s1553-7250(05)31060-9

Klein, K. J., \& Sorra, J. S. (1996). The challenge of innovation implementation. Academy of Management Review, 21(4), 1055-1080. doi:10.5465/amr.1996.9704071863

Koivunen, M., Niemi, A., \& Hupli, M. (2015). The use of electronic devices for communication with colleagues and other healthcare professionals - nursing professionals' perspectives. Journal of Advanced Nursing, 71(3), 620-631. doi:10.1111/jan.12529

Kuhlmann, S., Ahlers-Schmidt, C., \& Steinberger, E. (2014). TXT@WORK: Pediatric hospitalists and text messaging. Telemedicine and e-Health, 20(7), 647-652. doi:10.1089/tmj.2013.0200

Liamputtong, P. (2013). Research methods in health, foundations for evidence-based practice (2nd ed.). South Melbourne, Victoria: Oxford University Press

Lo, V., Wu, R. C., Morra, D., Lee, L., \& Reeves, S. (2012). The use of smartphones in general and internal medicine units: A boon or a bane to the promotion of interprofessional collaboration? Journal of Interprofessional Care, 26(4), 276-282. doi:10.3109/13561820.2012.663013

Machon, M., Knighten, M. L., \& Sohal, J. (2020). Improving clinical communication and collaboration through technology: A benefits analysis for nurse leaders. Nurse Leader. Advance online publication. doi:10.1016/j.mnl.2020.06.003 
Martin, G., Khajuria, A., Arora, S., King, D., Ashrafian, H., \& Darzi, A. (2019). The impact of mobile technology on teamwork and communication in hospitals: A systematic review. Journal of the American Medical Informatics Association, 26(4), 339-355. doi:10.1093/jamia/ocy175

Martinelli, R., \& Milosevic, D. (2016). Project management toolbox (2nd ed.). Hoboken, NJ: Wiley.

Maryn, Y., Ysenbaert, F., Zarowski, A., \& Vanspauwen, R. (2017). Mobile communication devices, ambient noise, and acoustic voice measures. Journal of Voice, 31(2), 248.e11248.e23. doi:10.1016/j.jvoice.2016.07.023

McBride, D. L. (2015). Distraction of clinicians by smartphones in hospitals: A concept analysis. Journal of Advanced Nursing, 71(9), 2020-2030. doi:10.1111/jan.12674

Mehrzad, R., \& Barza, M. (2015). Are physician pagers an outmoded technology? Technology \& Health Care, 23(3), 233-241. doi:10.3233/THC-140865

Menon, R., \& Rivett C. (2019). Time-motion analysis examining of the impact of Medic Bleep, an instant messaging platform, versus the traditional pager: A prospective pilot study. Digital Health, 5, 1-2. doi:10.1177/2055207619831812

Michel-Verkerke, M., \& Spil, T. (2013). The USE IT-adoption-model to predict and evaluate adoption of information and communication technology in healthcare. Methods of Information in Medicine, 52(6), 475-483. doi:10.3414/ME12-01-0107

Mickan, S., Atherton, H., Roberts, N. W., Heneghan, C., \& Tilson, J. (2014). Use of handheld computers in clinical practice: A systematic review. BMC Medical Informatics and Decision Making, 14(1), 56. doi:10.1186/1472-6947-14-56 
Moher, D., Liberati, A., Tetzlaff, J., \& Altman D. (2009). Preferred reporting items for systematic reviews and meta-analyses: The PRISMA statement. PLoS Med 6(7), e1000097. doi:10.1371/journal.pmed1000097

Moore, S., \& Jayewardene, D. (2014). The use of smartphones in clinical practice. Nursing Management - UK, 21(4), 18-22. doi:10.7748/nm.21.4.18.e1225

Motulsky, A., Wong, J., Cordeau, J.-P., Pomalaza, J., Barkun, J., Tamblyn, R., \& Wong, J. (2017). Using mobile devices for inpatient rounding and handoffs: An innovative application developed and rapidly adopted by clinicians in a pediatric hospital. Journal of the American Medical Informatics Association, 24(e1), e69-e78. doi:10.1093/jamia/ocw107

Moule, P., \& Goodman, M. (2014). Nursing research (2nd ed.). Los Angeles, CA: Sage.

Nagler, A., Schlueter, J., Johnson, C., Griffith, B., Prewitt, J., Sloane, R., \& Adams, M. (2014). Calling for collaboration: Piloting smartphones to discover differences between users and devices. Teaching \& Learning in Medicine, 26(3), 258-265. doi:10.1080/10401334.2014.910461

Nilsen, P. (2015). Making sense of implementation theories, models and frameworks. Implementation Science, 10(1). doi:10.1186/s13012-015-0242-0

Patel, N., Siegler, J., Stromberg, N., Ravitz, N., \& Hanson, C. (2016). Perfect storm of inpatient communication needs and an innovative solution utilizing smartphones and secured messaging. Applied Clinical Informatics, 7(3), 777-789. doi:10.4338/aci-2015-11-ra0151

Polit, D., \& Beck, C. (2018). Essentials of nursing research: Appraising evidence for nursing practice. Philadelphia, PA: Wolters Kluwer. 
Ponemon Institute. (2014). The Imprivata report on the economic impact of inefficient communications in healthcare. Retrieved from https://www.ponemon.org/local/upload/file/2014 Imprivata Report FINAL 3(1).pdf

Przybylo, J. A., Wang, A., Loftus, P., Evans, K. H., Chu, I., \& Shieh, L. (2014). Smarter hospital communication: Secure smartphone text messaging improves provider satisfaction and perception of efficacy, workflow. Journal of Hospital Medicine, 9(9), 573-578. doi:10.1002/jhm.2228

Ranganathan, P., Pramesh, C. S., \& Buyse, M. (2015). Common pitfalls in statistical analysis: Clinical versus statistical significance. Perspectives in Clinical Research, 6(3), 169-170. doi:10.4103/2229-3485.159943

Redelmeier, D. A., \& Detsky, A. S. (2013). Pitfalls with smartphones in medicine. Journal of General Internal Medicine, 28(10), 1260-1263. doi:10.1007/s11606-013-2467-4

Ross, S., \& Forgie, S. (2012). Distracted doctoring: Smartphones before patients? Canadian Medical Association Journal, 184(12), 1440. doi:10.1503/cmaj.120462

Rozario, D. (2018). Optimization of communication in the surgical program via instant messaging, web-based surveys, newsletters, websites, smartphones and telemedicine: The experience of Oakville Trafalgar Memorial Hospital. Canadian Journal of Surgery, 61(4), E4-E6. doi:10.1503/cjs.004418

Runyon, B. (2018). Market guide for clinical communication and collaboration. Retrieved from https://www.gartner.com/doc/3514617/market-guide-clinical-communicationcollaboration

Selanders, L., \& Crane, P., (2012). The voice of Florence Nightingale on advocacy. Online Journal of Issues in Nursing, 17(1). doi:10.3912/OJIN.Vol17No01Man01 
Siwicki, B. (2018). Communications platform gains efficiencies, cuts discharge time at Avera Health. Retrieved from https://www.healthcareitnews.com/news/communicationsplatform-gains-efficiencies-cuts-discharge-time-avera-health

Taylor, B., Kermode, S., \& Roberts, K. (2006). Research in nursing and healthcare: Evidence for practice. Melbourne, Australia: Cengage Learning.

Thomas, C. (2013). Smartphones and computer tablets: Friend or foe? Journal of Nursing Education and Practice, 4(2). doi:10.5430/jnep.v4n2p210

University of San Francisco. (2019). Our values. Retrieved from https://www.usfca.edu/aboutusf/who-we-are/our-values

VanDusen, K. A. (2017). Calling on smartphones to enhance patient care. Nursing, 47(11), 1-2. doi:10.1097/01.nurse.0000525993.44109.f9

Vermeir, P., Vandijck, D., Degroote, S., Peleman, R., Verhaeghe, R., Mortier, E., ... Vogelaers, D. (2015). Communication in healthcare: A narrative review of the literature and practical recommendations. International Journal of Clinical Practice, 69(11), 12571267. doi:10.1111/ijcp. 12686

Webb, C., Spina., S., \& Young., S. (2016). Integrating smartphone communication strategy and technology into clinical practice: A mixed methods research study. Health Policy and Technology, 5(4), 370-375. doi:10.1016/j.hlpt.2016.07.004

Whitlow, M., Drake, E., Tullman, D., Hoke, G., \& Barth, D. (2014). Bringing technology to the bedside using smartphones to improve interprofessional communication. Computers, Informatics, Nursing, 32(7), 305-311. doi:10.1097/cin.0000000000000063 
Wu, R., Tzanetos, K., Morra, D., Quan, S., Lo, V., \& Wong, B. (2013). Educational impact of using smartphones for clinical communication on general medicine: More global, less local. Journal of Hospital Medicine, 8(7), 365-372. doi:10.1002/jhm.2037 


\section{Appendices}

\section{Facility Departments}

\begin{tabular}{|c|c|c|c|c|c|}
\hline & Unit Name & $\begin{array}{l}\text { \# of Beds/ } \\
\text { Bays/Rooms }\end{array}$ & Population & Unit Type & Specialty \\
\hline \multirow{7}{*}{$\begin{array}{c}\text { Acute and } \\
\text { Critical Care }\end{array}$} & DOU & 22 & $\begin{array}{l}\text { Adult - } \\
\text { Inpatient (IP) }\end{array}$ & Step Down-Adult & $\begin{array}{l}\text { Med-Surg Step- } \\
\text { down }\end{array}$ \\
\hline & $\overline{\mathrm{ICU}}$ & 30 & Adult - IP & Critical Care-Adult & Medical ICU \\
\hline & $\begin{array}{l}\text { Med/Surg - } 4 \\
\text { West }\end{array}$ & 32 & Adult - IP & Med-Surg Adult & \\
\hline & $\begin{array}{l}\text { Med/Surg - } 5 \\
\text { West }\end{array}$ & 32 & Adult - IP & Med-Surg Adult & \\
\hline & $\begin{array}{l}\text { Med/Surg/Tele } \\
-5 \text { East }\end{array}$ & 32 & Adult - IP & Med-Surg Adult & $\begin{array}{l}\text { Cardiac Med- } \\
\text { Surg }\end{array}$ \\
\hline & Tele - 6 East & 32 & Adult - IP & Medical Adult & Cardiac Med \\
\hline & Tele - 6 West & 32 & Adult - IP & Medical Adult & Cardiac Med \\
\hline \multirow{5}{*}{$\begin{array}{l}\text { Maternal and } \\
\text { Child Health }\end{array}$} & Neonatal ICU & 49 & $\begin{array}{l}\text { Neonatal - } \\
\text { Inpatient }\end{array}$ & $\begin{array}{l}\text { Critical Care-Neonate } \\
\text { Level III }\end{array}$ & \\
\hline & $\begin{array}{l}\text { Family } \\
\text { Centered Care }\end{array}$ & 48 & $\begin{array}{l}\text { Obstetric- } \\
\text { Inpatient }\end{array}$ & Antepartum/Postpartum & \\
\hline & $\begin{array}{l}\text { Labor and } \\
\text { Delivery }\end{array}$ & 18 & $\begin{array}{l}\text { Obstetric- } \\
\text { Inpatient }\end{array}$ & LDRP & \\
\hline & Pediatric ICU & 8 & $\begin{array}{l}\text { Pediatric - } \\
\text { Inpatient }\end{array}$ & Critical Care-Pediatric & \\
\hline & Pediatrics & 17 & $\begin{array}{l}\text { Pediatric - } \\
\text { Inpatient }\end{array}$ & Med-Surg Pediatric & \\
\hline \multirow{4}{*}{$\begin{array}{c}\text { Peri- } \\
\text { operative } \\
\text { Services }\end{array}$} & KP-MCX OR & 14 & $\begin{array}{l}\text { Perioperative } \\
\text { Services Hosp }\end{array}$ & $\begin{array}{l}\text { OR-Reduced staff after } \\
\text { hours }\end{array}$ & Hospital \\
\hline & $\begin{array}{l}\text { KP-MCX } \\
\text { PACU }\end{array}$ & 64 & $\begin{array}{l}\text { Perioperative } \\
\text { Services Hosp }\end{array}$ & $\begin{array}{l}\text { Pre/Postoperative } \\
\text { includes Phase I }\end{array}$ & Hospital \\
\hline & BLF OR & Not in Scope & $\begin{array}{l}\text { Perioperative } \\
\text { Services }\end{array}$ & $\begin{array}{l}\text { OR-No afterhours } \\
\text { services }\end{array}$ & Free-standing \\
\hline & BLF PACU & Not in Scope & $\begin{array}{l}\text { Perioperative } \\
\text { Services - }\end{array}$ & $\begin{array}{l}\text { Pre/Postoperative } \\
\text { includes Phase I }\end{array}$ & Free-standing \\
\hline
\end{tabular}




\begin{tabular}{|c|l|l|l|l|l|}
\hline \multirow{5}{*}{ ED } & Unit Name & $\begin{array}{c}\text { \# of Beds/ } \\
\text { Bays/Rooms }\end{array}$ & Population & Unit Type & Specialty \\
\hline \multirow{5}{*}{$\begin{array}{c}\text { Emergency } \\
\text { Department }\end{array}$} & 79 & $\begin{array}{l}\text { Emergency } \\
\text { Services }\end{array}$ & $\begin{array}{l}\text { ED-Greater than 80,000 } \\
\text { Annual Visits }\end{array}$ & $\begin{array}{l}\text { Adult/Pediatric } \\
\text { ED }\end{array}$ \\
\cline { 2 - 6 } & Home Health & Not Applicable & Workgroup & Hospice/Palliative Care & \\
\cline { 2 - 7 } & Hospice & Not Applicable & Workgroup & Hospice/Palliative Care & \\
\cline { 2 - 6 } & $\begin{array}{l}\text { Specialty } \\
\text { Nurses }\end{array}$ & Not Applicable & Workgroup & Vascular Access RNs & \\
\cline { 2 - 6 } & $\begin{array}{l}\text { Utilization } \\
\text { Management }\end{array}$ & Not Applicable & Workgroup & Case Management & \\
\cline { 2 - 6 } & Hemodialysis & $\begin{array}{l}\text { Not } \\
\text { Applicable }\end{array}$ & $\begin{array}{l}\text { Care Based at } \\
\text { Hospital }\end{array}$ & Procedural Unit & Dialysis \\
\hline
\end{tabular}




\section{Appendix B}

\section{Go-Live Departments and Their Devices}

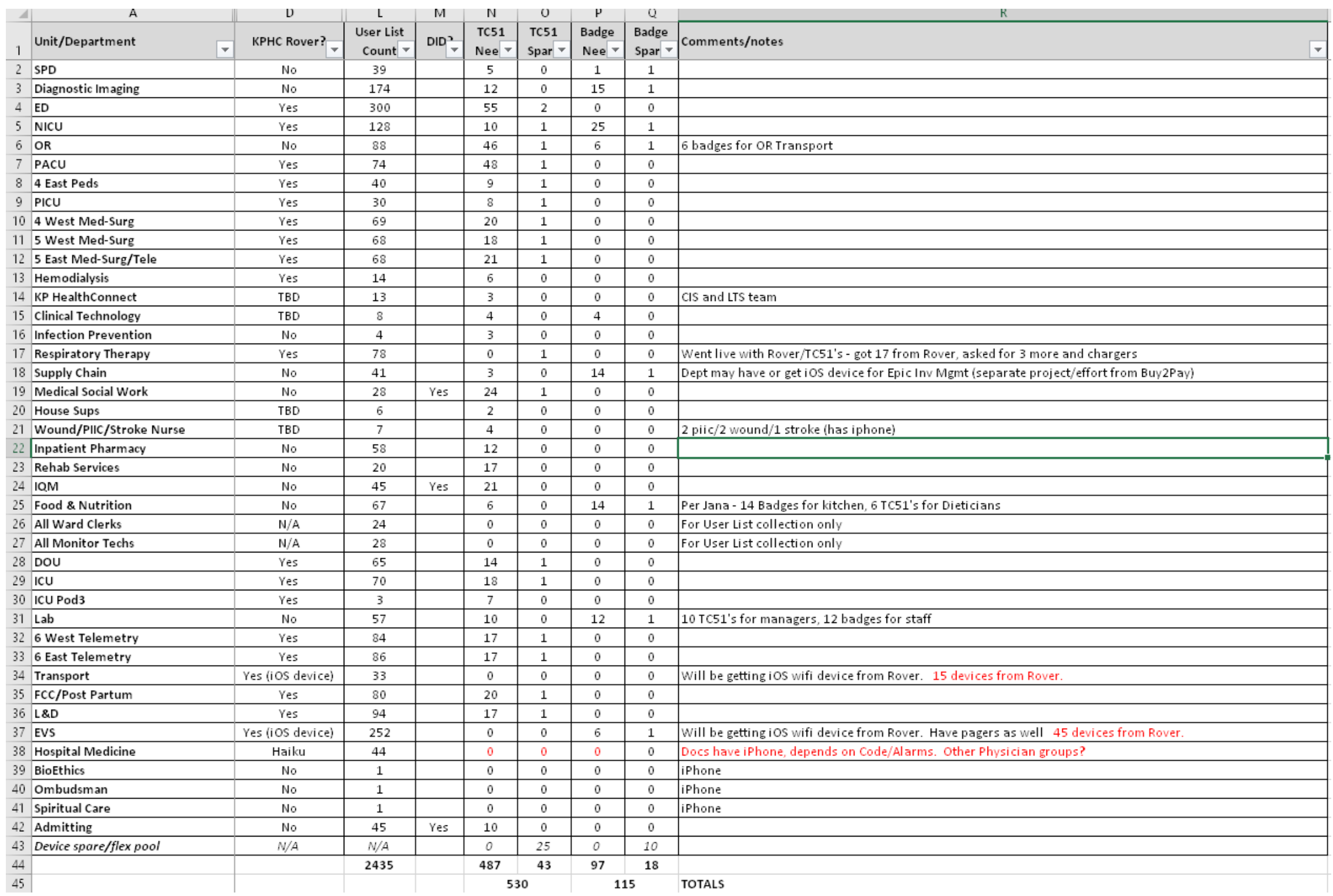


Appendix C

\section{Current and Future Devices}

Current:

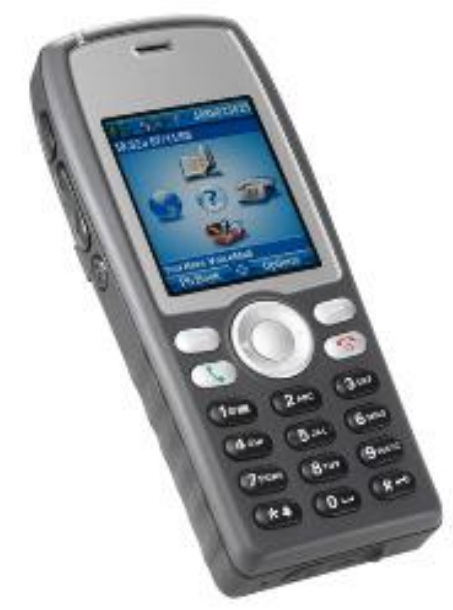

Cisco 7925

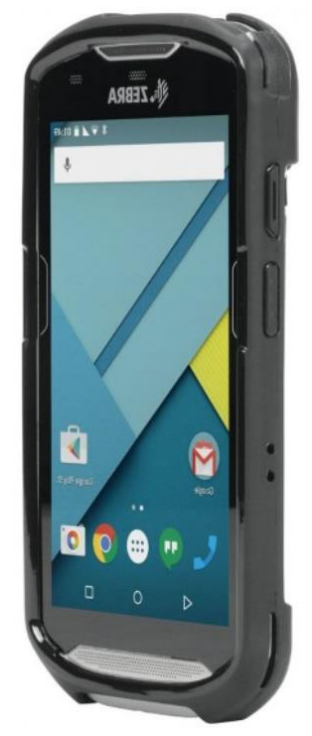

Zebra TC51
Future:

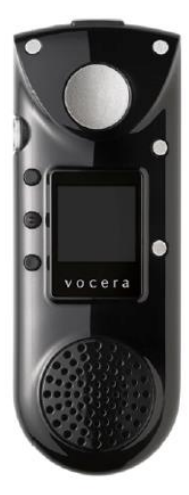

Vocera Badge 


\section{Appendix D}

\section{PRISMA Flow Diagram}

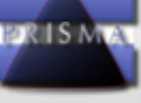

\section{PRISMA 2009 Flow Diagram}

Michelle Machon, 2019 Review of Literature

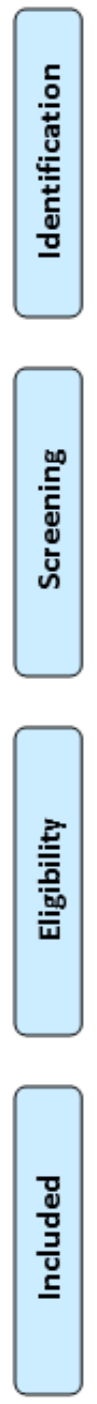

Records identified through database searching

$(n=127)$
Additional records identified through other sources $(n=9)$

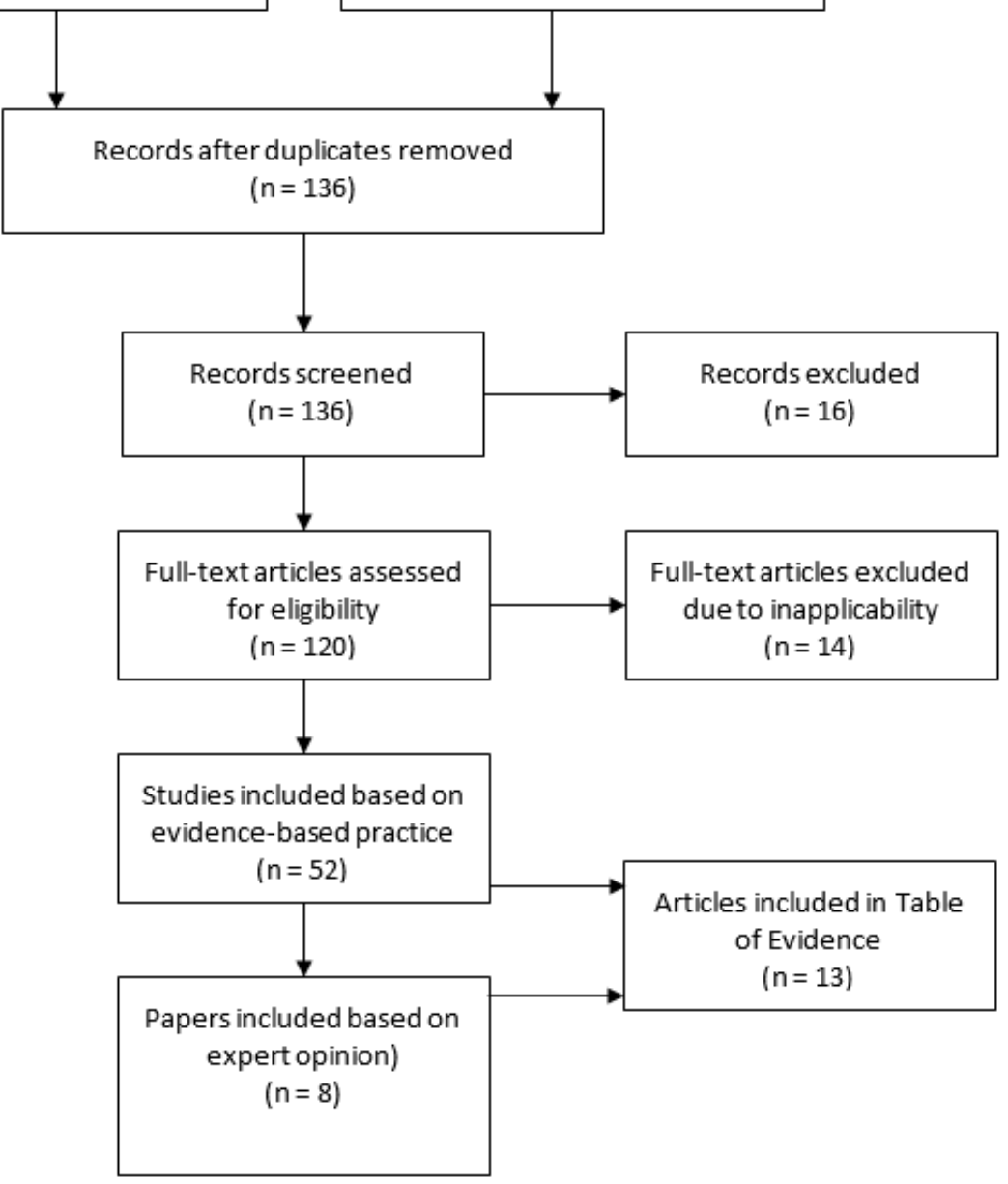




\section{Appendix E}

\section{Johns Hopkins Research Evidence Appraisal Tool}

\section{Johns Hopkins Nursing Evidence-Based Practice Appendix E: Research Evidence Appraisal Tool}

\begin{tabular}{|l|l|}
\hline Evidence level and qualty rating: & \\
\hline Artide twe: & Number: \\
\hline Author(s): & Publeation date: \\
\hline & \\
\hline
\end{tabular}

Journal:

[composition and stze]:

Does this evidenee address my EBP

Q Yes a No

question?

Do not procesd with appralsal of this evidence.

Is this study:

- QualNitative (colection, analysis, and reporting of numerical data)

Messurebledste (how many; how much; or how often) used to fonmulatefacts, uncover patterns in researdh, and generalize results from a lorger sample population; provides observed effects of a program, probiem, or condition, messured precisely, rather than through resesccher interpretation of dsta. Common methods aresurveys, face-to-facestruchured interviews, observotions, and reviews of records ar dccuments. Statietical tests are used indata anahyis.

Go to Section I: Quaktitative

- Qualitative (collection, snsilysis, and reporting of narrstive data)

Rich narrative documents areused for uncovering themes; describes a problem or condition from the point of view of those experiencing it. Common methods arefocus groups, individual intervievs (urstructured or semistruchured), and participation/observations. Samplesizes aresmsl and are determined when dsta saturation is schieved. Dats soturation is resched when the researcher identifes that no new themes emerge and redundancy is ccourring. Synthesis is used in dsta analysis. Often a starting point for studies when little research eoists; may use reults to design empirical studies. The resescher describes, anahyzes, and interprets reports, descriptions, and observations from partiopants.

Go to Section lt: Qualitative

- Moced methods (results reported both numericaly and narratively)

Both quaNtitative and quslitative methods are used in the study design. Using both approsches, in combination, provides a better understanding of resesch problems than using ether approach alane. Samplesizes vary based on methods usad. Dota collection involves collecting and analyzing both quaNtitative and quaLitativedstain asinglestudy ar series of studies. Interpretation is continual and can influence stages in the research process.

Go to Section I for QuaNtitative components and Section ll for Qualitative components

Q Tee Johns Dogkina Dorgital' The Jahn Hapkins Leivernity 


\section{Johns Hopkins Nursing Evidence-Based Practice Appendix E: Research Evidence Appraisal Tool}

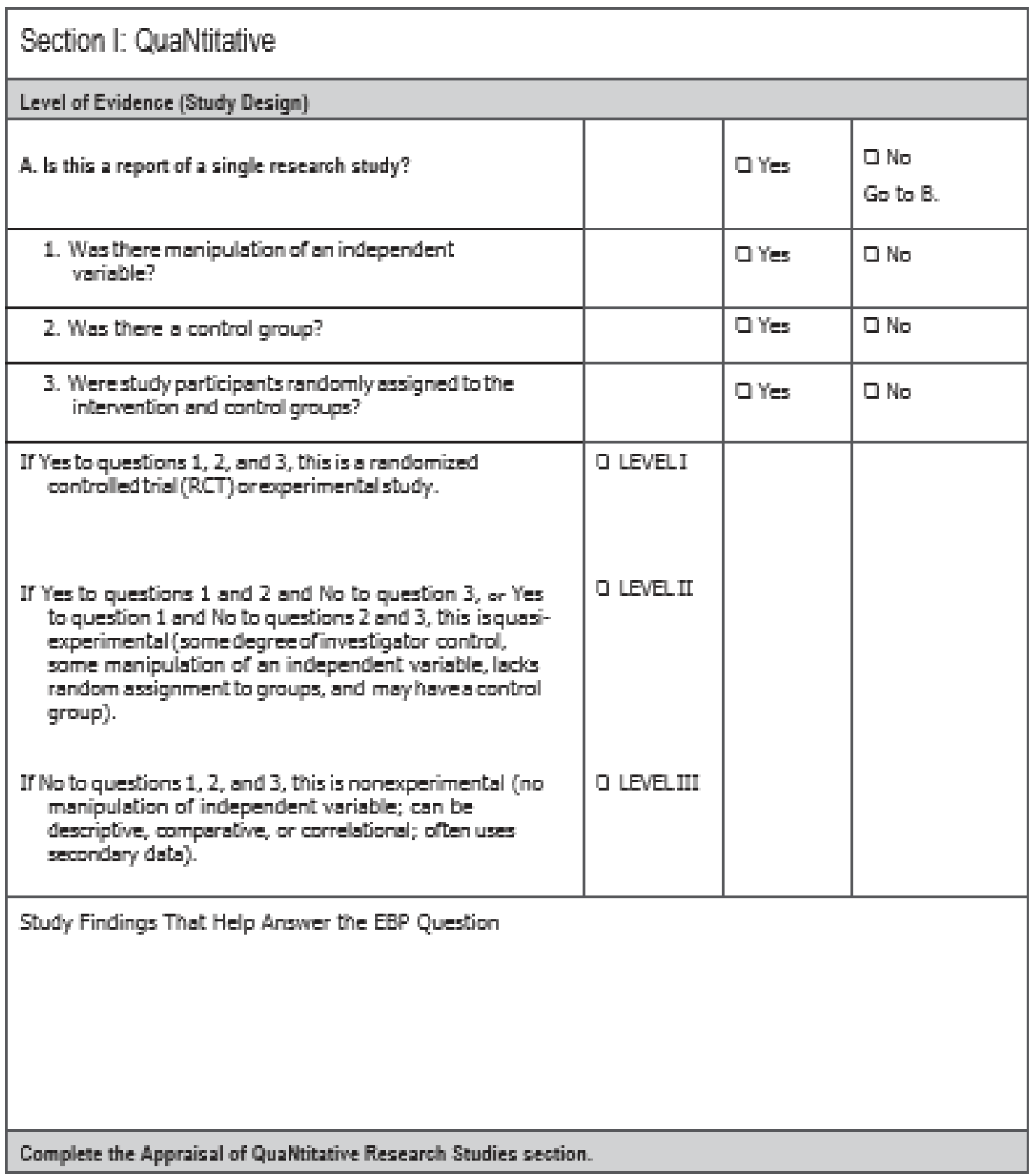




\section{Johns Hopkins Nursing Evidence-Based Practice Appendix E: Research Evidence Appraisal Tool}

\begin{tabular}{|c|c|c|c|}
\hline $\begin{array}{l}\text { B. Is thic a summary of multiple sources of } \\
\text { research evidence? }\end{array}$ & & $\begin{array}{l}\text { Q Yes } \\
\text { Continue }\end{array}$ & $\begin{array}{l}\text { Q No } \\
\text { Go to Appendix F }\end{array}$ \\
\hline $\begin{array}{l}\text { 1. Does it emplay a comprehensive } \\
\text { sesredh strotegy and rigorous appraisal } \\
\text { method? } \\
\text { If this study indudes resesrch, } \\
\text { nonresesrch, and experiential } \\
\text { evidence, itis anintegrotivereview. } \\
\text { Ses Appendix F. }\end{array}$ & & Q Yes & $\begin{array}{l}\text { Q No } \\
\text { Go to Appendix F }\end{array}$ \\
\hline 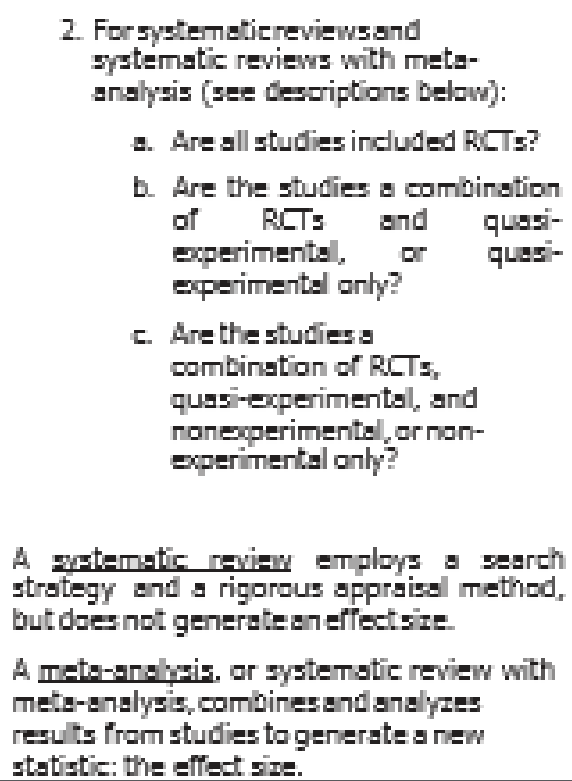 & $\begin{array}{l}\text { 口 Level I } \\
\text { Q Leved II } \\
\text { Q Leved III }\end{array}$ & & \\
\hline \multicolumn{4}{|c|}{ Study Findings That Help Answer the EBP Question } \\
\hline Complete the Appraisal of Systematic Revie & or Witho & Analyy & etion. \\
\hline
\end{tabular}




\section{Johns Hopkins Nursing Evidence-Based Practice Appendix E: Research Evidence Appraisal Tool}

\begin{tabular}{|c|c|c|c|}
\hline \multicolumn{4}{|l|}{ Appraisal of QuaNtitative Research Studies } \\
\hline $\begin{array}{l}\text { Does the researcher identify what is known and not known about the } \\
\text { problem and haw thestudy will add ress any gaps in knowledge? }\end{array}$ & $\square Y e$ & $\square$ No & \\
\hline Was the purpose of the study clearly presented? & QYes & $\square$ No & \\
\hline $\begin{array}{l}\text { Was the literature review current(most sources within the postfive years } \\
\text { or aseminal study)? }\end{array}$ & ares & $\square$ No & \\
\hline Was sample size sufficient based an study design and rationale? & $\square Y e$ & $\square$ No & \\
\hline \multicolumn{4}{|l|}{ If there is a control group: } \\
\hline $\begin{array}{l}\text { "Were the charecteristics and/or demographics similar in both the control } \\
\text { and intervention groups? }\end{array}$ & ares & No & $\square N / A$ \\
\hline - If muttiple settings were used, were the settings similar? & 口 Yes & $\square$ No & $\square N / A$ \\
\hline -Were all groups equaly trested except for the intervention group(s)? & $\square Y e$ & $\square$ No & $\square N / A$ \\
\hline Are data collection methods described clearly? & $\square Y e$ & $\square$ No & \\
\hline Were the instruments reliable (Cronbosh's $\alpha$ [alpha] $>0.70)$ ? & a Yes & $\square$ No & $\square N / A$ \\
\hline Was instrument validty discuseed? & $\square Y e$ & $\square$ No & $\square N / A$ \\
\hline If surveys or questionnaires were used, was the responserote $\geq 25 \%$ ? & $\square Y e$ & $\square$ No & $\square N / A$ \\
\hline Were the results presented dearly? & QYes & $\square$ No & \\
\hline $\begin{array}{l}\text { If tableswerepresented, was the narrativeconsistent with thetable } \\
\text { content? }\end{array}$ & $\square Y e$ & $\square$ No & $\square N / A$ \\
\hline Were study limitotions identified and addressed? & $\square Y e$ & $\square$ No & \\
\hline Were conclusians based on results? & ares & $\square$ No & \\
\hline \multicolumn{4}{|l|}{ Go to Quality Rating for QuaNtitative Studies section } \\
\hline \multicolumn{4}{|l|}{ Appraisal of Systematic Review (With or Without Meta-Analysis) } \\
\hline Were the variables of interest dearly identified? & $\square Y e$ & $\square$ No & \\
\hline \multicolumn{4}{|l|}{ Was the search comprehensive and reproducible? } \\
\hline - Key vesrch terms stated & ares & $\square$ No & \\
\hline - Multiple databases searched and identified & $\square Y e$ & $\square$ No & \\
\hline - Inclusion and exclusion criteria stated & $\square Y e$ & $\square$ No & \\
\hline $\begin{array}{l}\text { Was there a flow diagram that included the number of studies } \\
\text { eliminated at eachilevel of review? }\end{array}$ & $\square Y e$ & $\square$ No & \\
\hline
\end{tabular}




\section{Johns Hopkins Nursing Evidence-Based Practice Appendix E: Research Evidence Appraisal Tool}

\begin{tabular}{|c|c|c|}
\hline $\begin{array}{l}\text { Were detsils of included studies presented (design, sample, } \\
\text { methods, results, outcomes, strengths, and limitations? }\end{array}$ & QYes & Q No \\
\hline $\begin{array}{l}\text { Weremethods for appraising thestrength of evidence (level and } \\
\text { quality) described? }\end{array}$ & ares & No \\
\hline Were conclusions bosed on results? & QYes & $\square$ No \\
\hline " Results were interpreted. & QYes & $\square$ No \\
\hline $\begin{array}{l}\text { - Condusions flowed logicaly from the interpretation and systematic } \\
\text { review question. }\end{array}$ & QYes & $\square$ No \\
\hline $\begin{array}{l}\text { Did the systematic review include a section addressing limitations } \\
\text { ond } \\
\text { how they were addressed? }\end{array}$ & $\square Y e$ & $\square$ No \\
\hline \multicolumn{3}{|l|}{ Quality Rating for QuaNtitative Studies } \\
\hline \multicolumn{3}{|l|}{ Complete quality rating for quaNtitative studies section. } \\
\hline \multicolumn{3}{|l|}{ Circle the appropriate quality rating below } \\
\hline \multicolumn{3}{|c|}{$\begin{array}{l}\text { A High quality: Consistent, generaizable results; sufficient sample size for thestudy design; sdequatte control; } \\
\text { definitive condusions; consistent recommendations based on comprehensive liftersture review thatindudes } \\
\text { thoroughreference to scientificevidence. }\end{array}$} \\
\hline \multicolumn{3}{|c|}{$\begin{array}{l}\text { B Good qualiry. Reasonably consistent results; sufficient sample size for the study design; some control, and } \\
\text { fsirlydefinitive conclusions; ressonsbly consistent recommendations based an fairly comprehensive } \\
\text { literature review that includessome reference to scientificevidence. }\end{array}$} \\
\hline \multicolumn{3}{|c|}{$\begin{array}{l}\text { CLew quality or major fllaws: Little evidence with inconsistent results; insufficient sample size for the study } \\
\text { design; conclusions cannot be drewn. }\end{array}$} \\
\hline \multicolumn{3}{|l|}{ Section II: QuaLitative } \\
\hline \multicolumn{3}{|l|}{ Level of Evidence (Study Design) } \\
\hline A. Is this a report of a single qualitative research study? & $\begin{array}{l}\text { QYes } \\
\text { Level } \\
\text { III }\end{array}$ & $\begin{array}{l}\square \text { No } \\
\text { Go to Section } \\
\text { II. B }\end{array}$ \\
\hline \multicolumn{3}{|l|}{ Study Findings That Help Answer the EBP Question } \\
\hline
\end{tabular}




\section{Johns Hopkins Nursing Evidence-Based Practice Appendix E: Research Evidence Appraisal Tool}

\begin{tabular}{|c|c|c|}
\hline \multicolumn{3}{|l|}{ Appraisal of a single QuaLitative Reaearch study } \\
\hline \multicolumn{3}{|l|}{ Was there a clearly identifiable and articulated: } \\
\hline " Purpase? & QYes & $\square$ No \\
\hline " Research question? & QYes & $\square$ No \\
\hline - Justification for method(s) used? & QYes & $\square$ No \\
\hline . Phenomenon that is the foous of the researdh? & QYes & $\square$ No \\
\hline Were study sample partiojponts representative? & QYes & $\square$ No \\
\hline Did they have knowiledge of or experience with the research ares? & QYes & $\square$ No \\
\hline Were partioipont dharacteristios described? & QYes & $\square$ No \\
\hline Was sompling adequate, as evidenced by achieving saturation of dots? & QYes & $\square$ No \\
\hline \multicolumn{3}{|l|}{ Dota anshysis: } \\
\hline $\begin{array}{l}\text { - Was a verification process used in every step by cheoking and } \\
\text { confirming with porticipants the trustworthiness of analysis and } \\
\text { interpretation? }\end{array}$ & 口Yes & $\square$ No \\
\hline $\begin{array}{l}\text { "Was there a description of how data were analyzed (i.e., method), by computer } \\
\text { or manualy? }\end{array}$ & QYes & $\square$ No \\
\hline Do findings support the narrative dats (quotes)? & QYes & $\square$ No \\
\hline $\begin{array}{l}\text { Do findings flow from resesrch question to data collected to analysis } \\
\text { undertaken? }\end{array}$ & QYes & $\square$ No \\
\hline Are condusions clearly explained? & QYes & 口 No \\
\hline \multicolumn{3}{|l|}{ Go to Quality Rating for Qualitative Studies section. } \\
\hline $\begin{array}{l}\text { B. For summaries of multiple qualitative research studies (meta-synthesis), was a } \\
\text { comprehensive gearch strategy and rigorous appraisal method used? }\end{array}$ & $\begin{array}{l}\text { QYes } \\
\text { Level } \\
\text { III }\end{array}$ & $\begin{array}{l}\text { No Go to } \\
\text { Appendix F. }\end{array}$ \\
\hline \multicolumn{3}{|l|}{ Study Findings That Help Answer the EBP Question } \\
\hline
\end{tabular}




\section{Johns Hopkins Nursing Evidence-Based Practice Appendix E: Research Evidence Appraisal Tool}

\begin{tabular}{|c|c|c|}
\hline \multicolumn{3}{|l|}{ Appraisal of Meta-Synthesis Studies } \\
\hline $\begin{array}{l}\text { Were the search strategy and criteria for selecting primary studies clearly } \\
\text { defined? }\end{array}$ & 口Yes & $\square$ No \\
\hline Were findings appropriste and convincing? & $\square$ Yes & $\square$ No \\
\hline \multicolumn{3}{|l|}{ Was a description of methods used to: } \\
\hline - Compare findings fram each study? & $\square$ Yes & $\square$ No \\
\hline m Interpret data? & $\square$ Yes & $\square$ No \\
\hline \multicolumn{3}{|l|}{ Did synthesis reflect: } \\
\hline - New insights? & a Yes & $\square$ No \\
\hline - Digcovery of esential festures of phenomena? & $\square$ Yes & $\square$ No \\
\hline -A fuller understanding of the phenomens? & $\square$ Yes & $\square$ No \\
\hline Was sufficient data presented to support the interpretations? & $\square$ Yes & $\square$ No \\
\hline \multicolumn{3}{|l|}{ Complete Quality Rating for QuaLtitative Studies section. } \\
\hline Quality Rating for Qualitative Studies & & \\
\hline
\end{tabular}

Circle the appropriate quality rating below

No commonly agreed-on principles exist for judging the quality of qua Litative studies. It is a subjective process besed on the extent to which study data contributes to synthesis and how much information is known about the researchers' efforts to meet the approisal criteris.

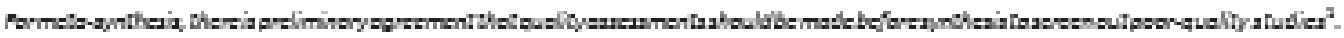

AB HighiGood quality is used for single studies and mets-syntheses)'2.

The report discusses efforts to enhance or evaluate the quality of the data and the averall inquiry in sufficient detail; and it describes the specific techniques used to enhance the quality of the inquiry. Evidence of some or all of the following is found in the report:

- Transparency: Describes haw information was documented to justify decisions, haw data were reviewed by others, and how themes and categories were formulsted.

- Diligence: Resds and reresds dota to check interpretstions; seeks apportunity to find multiple sources to corroborate evidence.

- Verification: The process of dhecking, confirming, and ensuring methodalogic colverence.

- Self-reflection and self-scrutiny: Being continuously aware of how a revearcher's experiences, background, or prejudices might shape and biss analysis and interpretations.

- Participant-driven inquiry. Participants shape the scope and breadth of questions; anslysis and interpretation give voice to thase who partioipated.

- Insightful interpretation: Dats and knowledge are linked in mesningful ways to relevant Rersture.

C Lower-quality studies contribute little to the averall review of findings and have few, if any, of the features listed for High/Good quality. 


\section{Johns Hopkins Nursing Evidence-Based Practice Appendix E: Research Evidence Appraisal Tool}

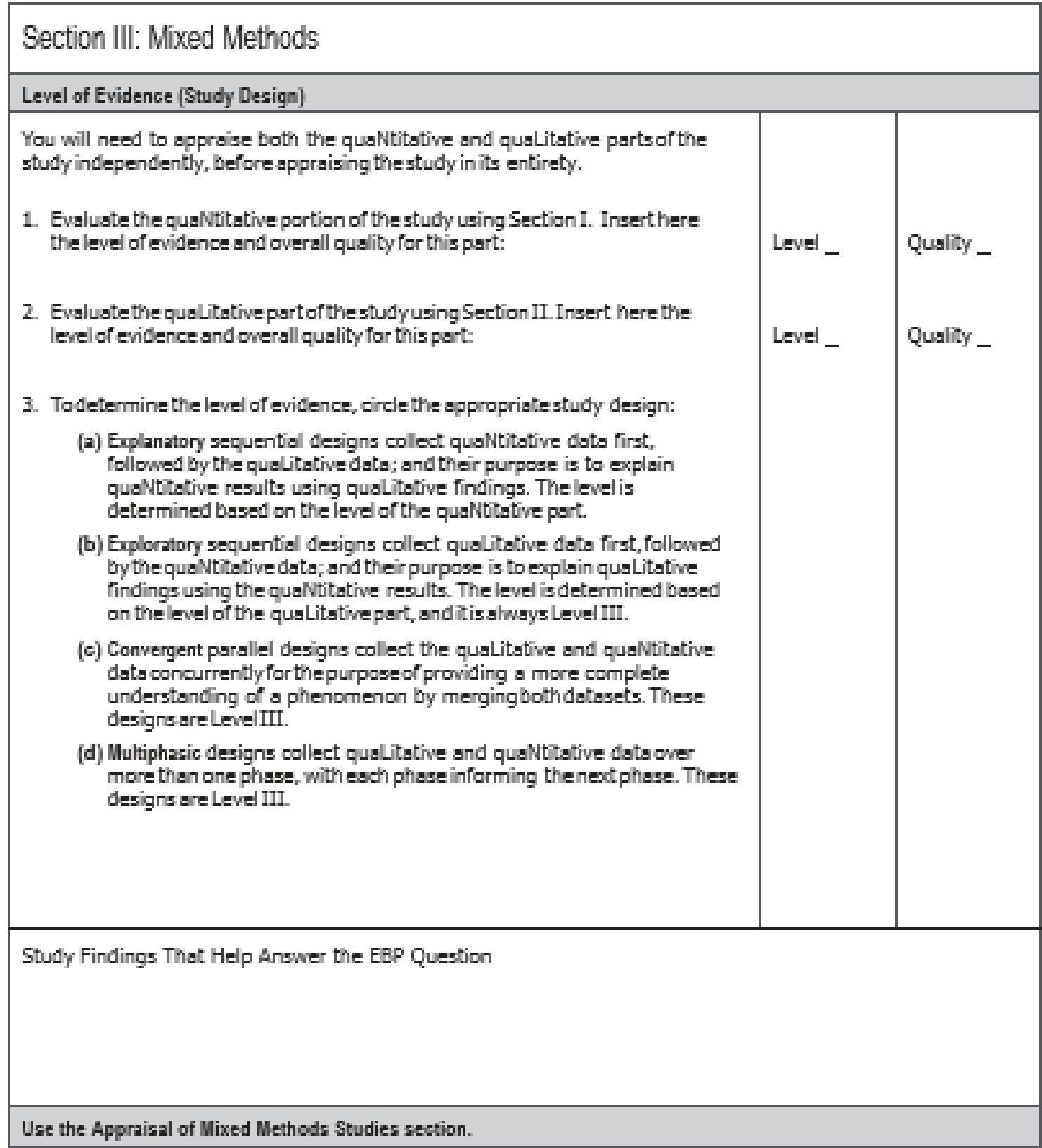




\section{Johns Hopkins Nursing Evidence-Based Practice Appendix E: Research Evidence Appraisal Tool}

\begin{tabular}{|c|c|c|c|}
\hline \multicolumn{4}{|l|}{ Appraisal of Mixed Methods Studies ${ }^{2}$} \\
\hline $\begin{array}{l}\text { Was the mixed-methods research design relevant to address the } \\
\text { quaNtitative and quaLitative research questions (or objectives)? }\end{array}$ & QYes & QNo & $\square N / A$ \\
\hline $\begin{array}{l}\text { Was the research design relevant to address the quaNittative and } \\
\text { qualitative aspects of the mixed-methods question (ar objective)? }\end{array}$ & QYes & QNo & $\square N / A$ \\
\hline $\begin{array}{l}\text { Forconvergent parallel designs, was the integrationof quaNtitative } \\
\text { and quaLitative dots (or results) relevent to address the research } \\
\text { question or ob/ective? }\end{array}$ & 口Yes & Q No & $\square$ N/A \\
\hline $\begin{array}{l}\text { For convergent parallel designs, were the limitations associated } \\
\text { with theintegration (forexample, the divergence of qualitativeand } \\
\text { qusNtitative dats or results) sumiciently addiressed? }\end{array}$ & 口Yes & $\square$ No & $\square N / A$ \\
\hline \multicolumn{4}{|l|}{ Quality Rating for Mixed-Methods Studies } \\
\hline \multicolumn{4}{|l|}{ Circle the appropriate quality rating belaw } \\
\hline \multicolumn{4}{|c|}{$\begin{array}{l}\text { A Highevality: Contsins high-quality quaNtitative and qualitativestudy components; highly relevant study } \\
\text { design; relavantintegration of dats or results; and careful considerotion of the limitations of the chosen } \\
\text { approach. }\end{array}$} \\
\hline \multicolumn{4}{|c|}{$\begin{array}{l}\text { B Goodevality: Contsins good-qualty qua Ntitative and qualitativestudy components; relevantstudy design; } \\
\text { moderately relevant integration of data or results; and some discussion of limitations of integration. }\end{array}$} \\
\hline \multicolumn{4}{|c|}{$\begin{array}{l}\text { C Low quality or meior flews: Contains law quality quaNtitative and qualitative study components; study design } \\
\text { nat relevant to revearch questions orobjectives; poorly integrated data or results; and noconsideration of limits } \\
\text { of integration. }\end{array}$} \\
\hline
\end{tabular}

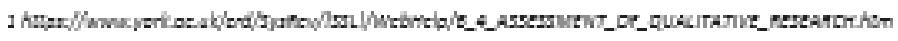

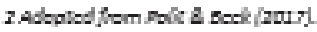

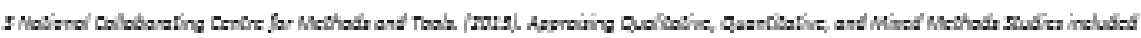

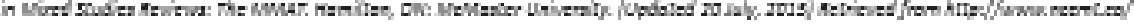
nerouraes/atarety/202 


\section{Appendix F}

\section{Johns Hopkins Non-Research Evidence Appraisal Tool}

\section{Johns Hopkins Nursing Evidence-Based Practice}

\section{Appendix F}

\section{Non-Research Evidence Appraisal}

\begin{tabular}{|c|c|}
\hline Evidence level and quality rating: & \\
\hline Article title: & Number: \\
\hline Author(s): & Publication date: \\
\hline \multicolumn{2}{|l|}{ Journal: } \\
\hline Setting: & Sample (composition and size): \\
\hline \multicolumn{2}{|c|}{$\begin{array}{l}\text { Does this evidence address my EBP question? } \\
\qquad \begin{array}{l}\square \text { Yes } \\
\square \text { No- Do not procoed with aporaisal of this evidence }\end{array}\end{array}$} \\
\hline
\end{tabular}

\section{„Clinical Practice Guidelines LEVEL IV}

Systematically developed recommendations from nationally recognized experts based on research evidence or expert consensus panel

aConsensus or Position Statement LEVEL IV

Systematically developed recommendations, based on research and nationally recognized expert opinion, that guide members of a professional organization in decision-making for an issue of concern

\begin{tabular}{|c|c|c|}
\hline - Are the types of evidence included identified? & $\square$ Yes & No \\
\hline $\begin{array}{l}\text { - Were appropriate stakeholders involved in the development of } \\
\text { recommendations? }\end{array}$ & $\square$ Yes & 口 No \\
\hline $\begin{array}{l}\text { - Are groups to which recommendations apply and do not apply dearly } \\
\text { stated? }\end{array}$ & $\square$ Yes & $\square$ No \\
\hline - Have potential biases been eliminated? & $\square$ Yes & ㅁ No \\
\hline - Does each recommendation have an identified level of evidence stated? & $\square$ Yes & $\square$ No \\
\hline - Are recommendations dear? & $\square$ Yes & $\square \mathrm{No}$ \\
\hline
\end{tabular}

Findings That Help Answer the EBP Question

Complete the corresponding quality rating section. 


\section{Johns Hopkins Nursing Evidence-Based Practice}

\section{Appendix F Non-Research Evidence Appraisal}

\begin{tabular}{|c|c|c|}
\hline \multicolumn{3}{|l|}{$\begin{array}{l}\text { iterature including scientif } \\
\text { opinions of experts }\end{array}$} \\
\hline \multicolumn{3}{|c|}{$\begin{array}{l}\text { aIntegrative review LEVELV } \\
\text { Summary of research evidence and theoretical literature; analyzes, compares themes, notes gaps in } \\
\text { the selected literature }\end{array}$} \\
\hline - Is subject matter to be reviewed clearly stated? & a Yes & $\square \mathrm{No}$ \\
\hline $\begin{array}{l}\text { - Is literature relevant and up-to-date (most sources are within the past five } \\
\text { years or dassic)? }\end{array}$ & $\square$ Yes & $\square \mathrm{No}$ \\
\hline $\begin{array}{l}\text { - Of the literature reviewed, is there a meaningful analysis of the condusions } \\
\text { across the artides induded in the review? }\end{array}$ & $\square$ Yes & $\square$ No \\
\hline - Are gaps in the literature identified? & $\square$ Yes & $\square \mathrm{No}$ \\
\hline - Are recommendations made for future practice or study? & a Yes & $\square \mathrm{No}$ \\
\hline \multicolumn{3}{|l|}{ Findings That Help Answer the EBP Question } \\
\hline
\end{tabular}

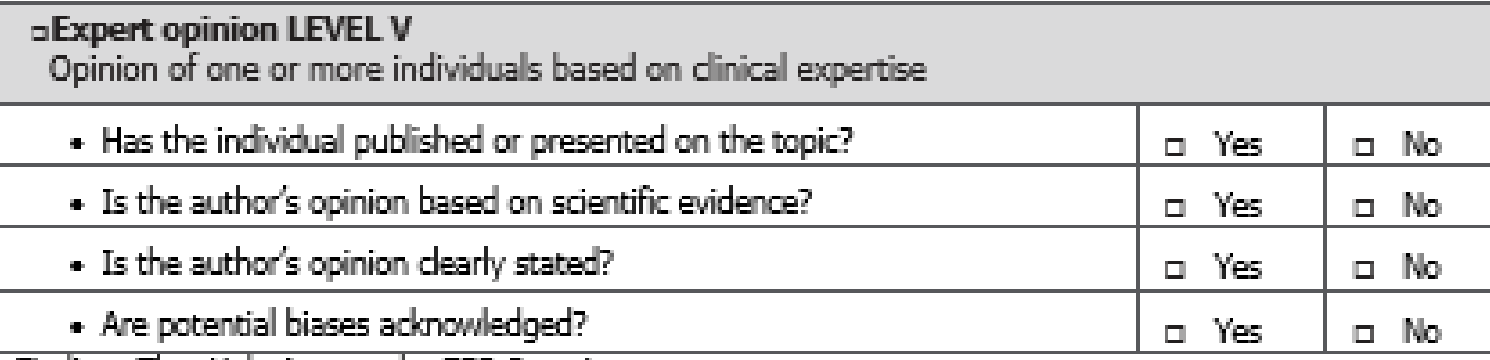

Findings That Help Answer the EBP Question

Complete the corresponding quality rating section. 


\section{Johns Hopkins Nursing Evidence-Based Practice}

\section{Appendix F}

\section{Non-Research Evidence Appraisal}

\section{Organizational Experience}

口 Quality improvement LEVEL $V$

Cyclical method to examine workflows, processes, or systems with a specific organization

口 Financial evaluation LEVEL $V$

Economic evaluation that apolies analytic techniques to identify, measure, and compare the cost and outcomes of two or more alternative programs or interventions

口. Program evaluation LEVEL $V$

Systematic assessment of the processes and/or outcomes of a program; can involve both quaNtitative and qualitative methods

\begin{tabular}{|l|c|c|c|}
\hline Setting: & \multicolumn{2}{l|}{ Sample Size/Composition: } \\
\hline - Was the aim of the project dearly stated? & aYes & aNo & \\
\hline - Was the method fully described? & aYes & aNo & \\
\hline - Were process or outcome measures identified? & aYes & aNo & \\
\hline - Were results fully described? & aYes & aNo & \\
\hline - Was interpretation dear and appropriate? & aYes & aNo & \\
\hline - Are components of cost/benefit or cost effectiveness analysis & aYes & aNo & al/A \\
\hline
\end{tabular}

Findings That Help Answer the EBP Question

Complete the corresponding quality rating section. 


\section{Johns Hopkins Nursing Evidence-Based Practice}

\section{Appendix F}

\section{Non-Research Evidence Appraisal}

口 Case report LEVEL V

In-depth look at a person or group or another social unit

- Is the purpose of the case report dearly stated?

- Is the case report dearly presented?

- Are the findings of the case report supported by relevant theory or research?

- Are the recommendations clearly stated and linked to the findings?

Findings That Hep Answer the EBP Question

Complete the corresponding quality rating.

\begin{tabular}{|c|c|c|c|}
\hline \\
\hline \multicolumn{4}{|c|}{ 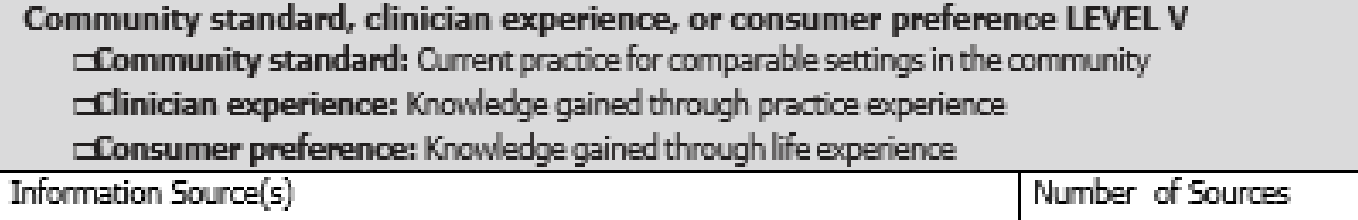 } \\
\hline \multirow{2}{*}{\multicolumn{4}{|c|}{$\begin{array}{l}\text { - Source of information has credible experience } \\
\text { - Opinions are dearly stated }\end{array}$}} \\
\hline & & & \\
\hline - Evidence obtained is consistent & aYes & aNo & 口il/A \\
\hline
\end{tabular}

Findings That Help You Answer the EBP Question

Complete the corresponding quality rating section. 


\title{
Johns Hopkins Nursing Evidence-Based Practice
}

\section{Appendix F Non-Research Evidence Appraisal}

Quality Rating for Clinical Practice Guidelines, Consensus, or Position Statements (Level IV)

\begin{abstract}
A High quality
Material officially sponsored by a professional, public, or private organization or a government agency; documentation of a systematic literature search strategy; consistent results with sufficient numbers of wel-designed studies; criteria-based evaluation of overall scientific strength and quality of induded studies and definitive conclusions; national expertise dearly evident; developed or revised within the past five years.

B Good quality Material officially sponsored by a professional, public, or private organization or a government agency; reasonably thorough and appropriate systematic literature search strategy; reasonably consistent results, sufficient numbers of well-designed studies; evaluation of strengths and limitations of included studies with fairly definitive conclusions; national expertise dearly evident: developed or revised within the past five years.
\end{abstract}

\section{Low quality or major flaw}

Material not sponsored by an official organization or agency; undefined, poorly defined, or limited literature search strategy; no evaluation of strengths and limitations of included studies; insufficient evidence with inconsistent results; condusions cannot be drawn; not revised within the past five years.

\section{Quality Rating for Organizational Experience (Level V)}

\section{A High quality}

Clear aims and objectives; consistert results across multiple settings; formal quality improvement or financial evaluation methods used; definitive conclusions; consistent recommendations with thorough reference to scientific evidence.

B Good quality

Clear aims and objectives; formal quality improvement or finanoial evaluation methods used; consistent results in a single setting; reasonably consistent recommendations with some reference to scientific evidence.

\section{Low quality or major flaws}

Undear or missing aims and objectives; inconsistent results; poorly defined quality; improvement/financial analysis method; recommendations cannot be made.

Quality Rating for Case Report, Integrative Review, Literature Review, Expert Opinion, Community Standard, Clinician Experience, Consumer Preference (Level V)

\section{A High quality}

Expertise is clearly evident, draws definitive condusions, and provides scientific rationale; thought leader in the field.

B Good quality

Expertise appears to be credible, draws fairly definitive conclusions, and provides logical argument for opinions.

\section{Low quality or major flaws}

Expertise is not discernable or is dubious; condusions cannot be drawn. 


\section{Appendix G}

\section{Evidence table}

\begin{tabular}{|c|c|c|c|c|c|c|c|}
\hline $\begin{array}{l}\text { Purpose of Article } \\
\text { or Review }\end{array}$ & Design/ Method & Sample/ Setting & $\begin{array}{l}\text { Conceptual } \\
\text { Framework }\end{array}$ & $\begin{array}{l}\text { Major Variables } \\
\text { Studied and their } \\
\text { Definitions) }\end{array}$ & $\begin{array}{l}\text { Measurement/ } \\
\text { Data Analysis }\end{array}$ & Findings & $\begin{array}{c}\text { Critical Appraisal Tool and Rating/ } \\
\text { Worth to Practice/ } \\
\text { Strengths and Weaknesses/ } \\
\text { Recommendations }\end{array}$ \\
\hline \multicolumn{8}{|c|}{ 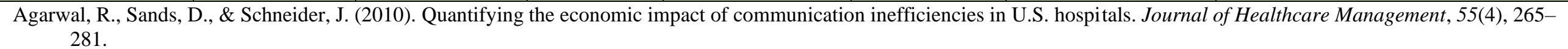 } \\
\hline $\begin{array}{l}\text { To develop a model } \\
\text { for quantifying the } \\
\text { economic burden of } \\
\text { poor communication } \\
\text { on hospital }\end{array}$ & $\begin{array}{l}\text { Design: Multi- } \\
\text { stage qualitative } \\
\text { study (three } \\
\text { stages) } \\
\text { Method } \\
\text { 1. Literature } \\
\text { review } \\
\text { 2. Stakeholder } \\
\text { Interviews } \\
\text { 3. Development } \\
\text { of a } \\
\text { quantitative } \\
\text { model }\end{array}$ & $\begin{array}{l}\text { Sample } \\
\text { Unknown \# } \\
\text { "Interviewees } \\
\text { included chief } \\
\text { nursing officers } \\
\text { (CNOs), chief } \\
\text { information } \\
\text { officers (CIOs), } \\
\text { chief medical } \\
\text { officers (CMOs), } \\
\text { physicians, } \\
\text { nurses, and } \\
\text { hospital chief } \\
\text { executive } \\
\text { officers } \\
\text { (CEOs)." } \\
\text { Setting: Seven } \\
\text { short term/acute- } \\
\text { care hospitals } \\
\text { that varied in } \\
\text { size, revenue and } \\
\text { location (urban } \\
\text { and suburban). }\end{array}$ & None noted & $\begin{array}{l}\text { Independent } \\
\text { Variable: } \\
\text { - MD time, } \\
\text { - RN time, } \\
\text { - length of stay, } \\
\text { - medical errors, } \\
\text { - stress, } \\
\text { - job satisfaction } \\
\text { - patient } \\
\text { experience } \\
\text { Dependent } \\
\text { Variable(s) } \\
\text { - resource } \\
\text { utilization, } \\
\text { - operational } \\
\text { effectiveness, } \\
\text { - work life } \\
\text { quality } \\
\text { - service quality }\end{array}$ & $\begin{array}{l}\text { Measurement } \\
\text { Hour-long } \\
\text { structured } \\
\text { interviews } \\
\text { Data analysis } \\
\text { Two } \\
\text { interviewers } \\
\text { independently } \\
\text { extracted } \\
\text { themes that } \\
\text { were } \\
\text { subsequently } \\
\text { compared to } \\
\text { validate and } \\
\text { triangulate } \\
\text { findings. }\end{array}$ & $\begin{array}{l}\text { The authors } \\
\text { identified specific } \\
\text { metrics ( MD time, } \\
\text { RN time, length of } \\
\text { stay, medical errors, } \\
\text { stress, job satisfaction } \\
\text { and patient } \\
\text { experience) for } \\
\text { resource utilization, } \\
\text { operational } \\
\text { effectiveness, work } \\
\text { life quality and } \\
\text { service quality }\end{array}$ & $\begin{array}{l}\text { Rating: } \\
\text { Level III A/B (High/ Good Quality) } \\
\text { Worth to practice } \\
\text { One of the only papers in the literature } \\
\text { that quantifies the effects of poor } \\
\text { communication in financial terms } \\
\text { Feasibility } \\
\text { Strong financial analysis based on } \\
\text { literature review and expert opinion } \\
\text { Strengths } \\
\text { Agreement in the themes extracted was } \\
92 \text { percent for all interviews. } \\
\text { Weaknesses } \\
\text { Older study (2010), Unknown number } \\
\text { of participants. No theory for } \\
\text { conceptual framework } \\
\text { Conclusions } \\
\text { This study is useful as it places a dollar } \\
\text { amount on wasted communication, } \\
\text { especially for increased length of stay. } \\
\text { Recommendations: } \\
\text { Further studies to check assumptions/ } \\
\text { conclusions to demonstrate if their } \\
\text { financial predictions were accurate. }\end{array}$ \\
\hline
\end{tabular}




\begin{tabular}{|c|c|c|c|c|c|c|c|}
\hline $\begin{array}{c}\text { Purpose of Article } \\
\text { or Review }\end{array}$ & Design/ Method & Sample/ Setting & $\begin{array}{c}\text { Conceptual } \\
\text { Framework }\end{array}$ & $\begin{array}{l}\text { Major Variables } \\
\text { Studied and their } \\
\text { Definitions) }\end{array}$ & $\begin{array}{l}\text { Measurement/ } \\
\text { Data Analysis }\end{array}$ & Findings & $\begin{array}{c}\text { Critical Appraisal Tool and Rating/ } \\
\text { Worth to Practice/ } \\
\text { Strengths and Weaknesses/ } \\
\text { Recommendations } \\
\end{array}$ \\
\hline \multicolumn{8}{|c|}{ Bautista, R., Rosenthal, S., Lin, T., \& Theng, Y. (2018). Predictors and outcomes of nurses use of smartphones for work purposes. Computers in Human Behavior, $84,360-374}$. \\
\hline $\begin{array}{l}\text { To address a } \\
\text { research gap by } \\
\text { developing and } \\
\text { testing a model to } \\
\text { analyze nurses use } \\
\text { of personal } \\
\text { smartphones. }\end{array}$ & $\begin{array}{l}\text { Design } \\
\text { Quantitative } \\
\text { survey } \\
\text { Method } \\
\text { A theory driven } \\
\text { (structural } \\
\text { equation } \\
\text { modeling) } \\
\text { analysis of } \\
\text { surveys }\end{array}$ & $\begin{array}{l}\frac{\text { Sample }}{517 \text { staff nurses }} \\
\text { Setting } \\
19 \text { tertiary } \\
\text { hospitals in the } \\
\text { Philippines }\end{array}$ & $\begin{array}{l}\text { Theory of } \\
\text { planned } \\
\text { behavior, } \\
\text { organization } \\
\text { al support } \\
\text { theory and } \\
\text { IT } \\
\text { consumerizat } \\
\text { ion theory }\end{array}$ & $\begin{array}{l}\text { Independent } \\
\text { Variable: } \\
\text { Survey to measure } \\
\text { how nurses use } \\
\text { their phones } \\
\text { Dependent } \\
\text { Variable(s) } \\
\text { Productivity of } \\
\text { nurses }\end{array}$ & $\begin{array}{l}\text { Measurement } \\
\text { Factor } \\
\text { analysis, } \\
\text { Kaiser-Meyer- } \\
\text { Olkin (KMO) } \\
\text { test for } \\
\text { sampling } \\
\text { adequacy and } \\
\text { Bartlett's test } \\
\text { of sphericity. } \\
\\
\text { Data Analysis } \\
\text { SPSS Statistics } \\
\text { 23 program } \\
\text { and Mplus } 7\end{array}$ & $\begin{array}{l}\text { Inductive norm, } \\
\text { descriptive norm and } \\
\text { perceived behavioral } \\
\text { control were } \\
\text { positively associated } \\
\text { with intention to use } \\
\text { smartphones for work } \\
\text { purposes. And it was } \\
\text { positively associated } \\
\text { with perceived work } \\
\text { productivity and } \\
\text { perceived quality of } \\
\text { care. } \\
\text { Six out of } 11 \\
\text { hypotheses were } \\
\text { supported with } \\
\text { statistical } \\
\text { significance (p < } \\
0.001, p=0.04, p= \\
0.02, p<0.0001 \text { and } \\
\text { p } 0.02)\end{array}$ & $\begin{array}{l}\text { Rating } \\
\text { Level II A/B } \\
\text { (High/Good Quality) } \\
\text { Worth to practice } \\
\text { Demonstrates the value of smartphones } \\
\text { to nurses in clinical practice } \\
\text { Feasibility } \\
\text { Strong, theory based quantitative study } \\
\text { Strengths } \\
\text { Having a theory-based approach to the } \\
\text { study (in the conceptual framework and } \\
\text { the measurement strategy) was a } \\
\text { strength } \\
\text { Weaknesses } \\
\text { No real description of the survey } \\
\text { weakens the study. } \\
\text { Conclusion } \\
\text { Concluded with statistical significance } \\
\text { that nurses perceived the use of } \\
\text { smartphones at work improved their } \\
\text { productivity and quality of care } \\
\text { Recommendations } \\
\text { Further analysis if the positive results } \\
\text { of nurses use of personal smart phones } \\
\text { is replicated in their attitudes to and use } \\
\text { of employer provided smartphones. }\end{array}$ \\
\hline
\end{tabular}




\begin{tabular}{|c|c|c|c|c|c|c|c|}
\hline $\begin{array}{l}\text { Purpose of Article } \\
\text { or Review }\end{array}$ & Design/Method & Sample/ Setting & $\begin{array}{l}\text { Conceptual } \\
\text { Framework }\end{array}$ & $\begin{array}{l}\text { Major Variables } \\
\text { Studied and their } \\
\text { Definitions) }\end{array}$ & $\begin{array}{l}\text { Measurement/ } \\
\text { Data Analysis }\end{array}$ & Findings & $\begin{array}{c}\text { Critical Appraisal Tool and Rating/ } \\
\text { Worth to Practice/ } \\
\text { Strengths and Weaknesses/ } \\
\text { Recommendations } \\
\end{array}$ \\
\hline \multicolumn{8}{|c|}{$\begin{array}{l}\text { Chatterjee, S., Chakraborty, S., Sarker, S., Sarker, S2., \& Lau, F. (2009). Examining the success factors for mobile work in healthcare: A deductive study. Decision Support Systems, } \\
\text { 46, 620-633. }\end{array}$} \\
\hline $\begin{array}{l}\text { To identify key } \\
\text { factors in the } \\
\text { literature that } \\
\text { influence the } \\
\text { success of "mobile } \\
\text { work" in healthcare }\end{array}$ & $\begin{array}{l}\text { Design } \\
\text { Deductive } \\
\text { literature } \\
\text { review } \\
\text { Note: while the } \\
\text { authors stated } \\
\text { this was a } \\
\text { deductive } \\
\text { review, it } \\
\text { appears to } \\
\text { resemble more } \\
\text { a qualitative } \\
\text { study. } \\
\\
\text { Method } \\
\text { "a consolidated } \\
\text { review of } \\
\text { literature in the } \\
\text { area of mobile } \\
\text { work in } \\
\text { healthcare" }\end{array}$ & $\begin{array}{l}\text { Sample } \\
70 \text { articles } \\
\text { Setting } \\
\text { Pub med and } \\
\text { Ovid search, key } \\
\text { terms utilized, } \\
\text { limited to four } \\
\text { years, English } \\
\text { language only, } \\
\text { irrelevant articles } \\
\text { excluded }\end{array}$ & $\begin{array}{l}\text { Delone and } \\
\text { Mclean's } \\
\text { Model of } \\
\text { Information } \\
\text { Systems } \\
\text { Success }\end{array}$ & $\begin{array}{l}\text { Independent } \\
\text { Variables: } \\
\text { - data processing } \\
\text { - information } \\
\text { access } \\
\text { - communicability } \\
\text { - portability } \\
\text { - task structure } \\
\text { - task urgency } \\
\text { - temporal } \\
\text { mobility } \\
\text { - spatial mobility } \\
\text { - contextual } \\
\text { mobility } \\
\text { - information } \\
\text { complexity } \\
\text { - system reliability } \\
\text { - system support } \\
\text { - use } \\
\text { - satisfaction } \\
\\
\text { Dependent } \\
\text { Variable(s)use } \\
\text { - satisfaction } \\
\text { - net benefits }\end{array}$ & $\begin{array}{l}\text { Measurement } \\
\text { Two coders } \\
\text { used a standard } \\
\text { coding scheme } \\
\text { reflecting the } \\
\text { constructs of } \\
\text { the model. } \\
\text { Interrater } \\
\text { reliability } \\
\text { assessed using } \\
\text { Cohen's kappa } \\
\text { Data Analysis } \\
\text { To assess the } \\
\text { impact of the } \\
\text { independent } \\
\text { variable on the } \\
\text { dependent } \\
\text { variable, the } \\
\text { authors } \\
\text { "conceptualize } \\
\text { d each } \\
\text { relationship in } \\
\text { the model as a } \\
\text { variance theory } \\
\text { relationship } \\
\text { where } \\
\text { independent } \\
\text { variables were } \\
\text { individually } \\
\text { considered as } \\
\text { necessary and } \\
\text { sufficient" }\end{array}$ & $\begin{array}{l}\text { Mixed support for } \\
\text { propositions in the } \\
\text { literature. One key } \\
\text { finding was that high } \\
\text { levels of data } \\
\text { processing is not } \\
\text { needed by healthcare } \\
\text { workers, as simple } \\
\text { communication is } \\
\text { what is most sought } \\
\text { after in mobile } \\
\text { devices. }\end{array}$ & $\begin{array}{l}\text { Rating: } \\
\text { Level III A/B } \\
\text { (High/ Good Quality) } \\
\text { Worth to practice } \\
\text { Provides strong rationale for the } \\
\text { benefits of healthcare mobile } \\
\text { technology and lists valued capabilities } \\
\text { Feasibility } \\
\text { Provides previously unknown } \\
\text { information about value of mobility in } \\
\text { healthcare } \\
\text { Strengths, } \\
\text { Strong literature review methodology } \\
\text { utilized using a theory drive approach } \\
\text { Weaknesses, } \\
\text { Older review (2009) } \\
\text { Conclusions } \\
\text { Healthcare workers would be positively } \\
\text { influenced by the capabilities of mobile } \\
\text { work including the ability to have data } \\
\text { processing, access to information, } \\
\text { communicability, portability, structure } \\
\text { to tasks, spatial mobility, urgency of } \\
\text { information, system reliability and } \\
\text { support. } \\
\text { Recommendations } \\
\text { Further studies on the benefits of the } \\
\text { other capabilities of smartphones }\end{array}$ \\
\hline
\end{tabular}




\begin{tabular}{|c|c|c|c|c|c|c|c|}
\hline $\begin{array}{l}\text { Purpose of Article } \\
\text { or Review }\end{array}$ & Design/ Method & Sample/ Setting & $\begin{array}{l}\text { Conceptual } \\
\text { Framework }\end{array}$ & $\begin{array}{l}\text { Major Variables } \\
\text { Studied and their } \\
\text { Definitions) }\end{array}$ & $\begin{array}{l}\text { Measurement/ } \\
\text { Data Analysis }\end{array}$ & Findings & $\begin{array}{c}\text { Critical Appraisal Tool and Rating/ } \\
\text { Worth to Practice/ } \\
\text { Strengths and Weaknesses/ } \\
\text { Recommendations } \\
\end{array}$ \\
\hline \multicolumn{8}{|c|}{$\begin{array}{l}\text { Hoonakker, P., Carayon, P., \& Cartmill, R. (2017). The impact of secure messaging on workflow in primary care: Results of a multiple-case, multiple-method study. International } \\
\text { Journal of Medical Informatics, 100, 63-76. }\end{array}$} \\
\hline $\begin{array}{l}\text { To examine the } \\
\text { impact of secure } \\
\text { messaging in } \\
\text { primary care clinics } \\
\text { (between staff, } \\
\text { providers and } \\
\text { patients) }\end{array}$ & $\begin{array}{l}\text { Design } \\
\text { Mixed method } \\
\text { (quantitative } \\
\text { and qualitative) } \\
\text { study } \\
\text { Method } \\
\text { Observation, } \\
\text { interviews and } \\
\text { survey }\end{array}$ & $\begin{array}{l}\text { Sample } \\
40 \text { observations/ } \\
\text { interviews over } \\
60 \text { hours and } 58 \\
\text { surveys } \\
\text { Setting } \\
\text { Five clinics in } \\
\text { Madison, } \\
\text { Wisconsin }\end{array}$ & None noted & $\begin{array}{l}\text { Independent } \\
\text { Variable: } \\
\text { Impact of having a } \\
\text { secure messaging } \\
\text { application } \\
\text { Dependent } \\
\text { Variable(s) } \\
\text { - quality of care } \\
\text { - patient safety } \\
\text { - end user } \\
\quad \text { satisfaction }\end{array}$ & $\begin{array}{l}\text { Measurement } \\
\text { Pre-visit } \\
\text { questionnaires, } \\
\text { observation } \\
\text { forms and } \\
\text { surveys } \\
\text { Analysis } \\
\text { For } \\
\text { observations/ } \\
\text { interviews: } \\
\text { analysis in } \\
\text { Dedoose data } \\
\text { analysis } \\
\text { program } \\
\text { For Surveys: } \\
\text { chi-square- } \\
\text { tests used to } \\
\text { determine } \\
\text { differences }\end{array}$ & $\begin{array}{l}\text { Convenience, ease of } \\
\text { patient } \\
\text { communication, ease } \\
\text { of answering simple } \\
\text { questions, workflow } \\
\text { efficiencies, and } \\
\text { improved information } \\
\text { flow were all } \\
\text { facilitators from the } \\
\text { technology. } \\
\text { Volume of messages, } \\
\text { lack of contextual } \\
\text { information, and } \\
\text { workflow } \\
\text { interruptions were all } \\
\text { classed as barriers }\end{array}$ & $\begin{array}{l}\text { Rating } \\
\text { Level II A/B High/Good quality } \\
\text { Worth to practice } \\
\text { Highlights the pros, cons and potential } \\
\text { pitfalls of healthcare secure messaging } \\
\text { Feasibility } \\
\text { Feasibility of secure messaging } \\
\text { depends on how it is implemented } \\
\text { Strengths, } \\
\text { Provides detailed arguments about the } \\
\text { benefits of secure messaging in in } \\
\text { healthcare. Provided hyperlink to data } \\
\text { collections tools. Identified statistical } \\
\text { significance between clinician and non- } \\
\text { clinician perceptions of the technology } \\
\text { Weaknesses, } \\
\text { Limited to outpatient clinics so hospital } \\
\text { workflows not discussed. } \\
\text { Survey instrument not fully validated. } \\
\text { Conclusion } \\
\text { Secure messaging is a tool that has the } \\
\text { potential to improve communication } \\
\text { and information flow. However, this is } \\
\text { dependent on the way it is implemented } \\
\text { and used. } \\
\text { Recommendations } \\
\text { Further studies to determine if the } \\
\text { implementation or policy decisions } \\
\text { were the reasons for different opinions } \\
\text { of staff, providers and patients. }\end{array}$ \\
\hline
\end{tabular}




\begin{tabular}{|c|c|c|c|c|c|c|c|}
\hline $\begin{array}{l}\text { Purpose of Article } \\
\text { or Review }\end{array}$ & Design/ Method & Sample/ Setting & $\begin{array}{l}\text { Conceptual } \\
\text { Framework }\end{array}$ & $\begin{array}{l}\text { Major Variables } \\
\text { Studied and their } \\
\text { Definitions) }\end{array}$ & $\begin{array}{l}\text { Measurement/ } \\
\text { Data Analysis }\end{array}$ & Findings & $\begin{array}{c}\text { Critical Appraisal Tool and Rating/ } \\
\text { Worth to Practice/ } \\
\text { Strengths and Weaknesses/ } \\
\text { Recommendations }\end{array}$ \\
\hline \multicolumn{8}{|c|}{$\begin{array}{l}\text { Lo, V., Wu, R. C., Morra, D., Lee, L., \& Reeves, S. (2012). The use of smartphones in general and internal medicine units: A boon or a bane to the promotion of interprofessional } \\
\text { collaboration? Journal of Interprofessional Care, 26(4), 276-282. }\end{array}$} \\
\hline $\begin{array}{l}\text { To determine the } \\
\text { perceptions of } \\
\text { internal medicine } \\
\text { staff about the use } \\
\text { of smartphones and } \\
\text { a web paging system } \\
\text { after they were } \\
\text { implemented in their } \\
\text { hospitals. }\end{array}$ & $\begin{array}{l}\text { Design } \\
\text { An explanatory } \\
\text { case study } \\
\text { approach } \\
\text { Note: } \\
\text { While the } \\
\text { authors } \\
\text { identified this } \\
\text { as a case study } \\
\text { approach, the } \\
\text { methodology } \\
\text { signifies a } \\
\text { qualitative } \\
\text { study } \\
\text { Method } \\
\text { In- depth semi- } \\
\text { structured } \\
\text { interviews }\end{array}$ & $\begin{array}{l}\text { Sample } \\
31 \text { staff } \\
\text { members, male } \\
\text { and female with } \\
\text { a range of ages: } \\
15 \text { registered } \\
\text { nurses, eight } \\
\text { physicians, four } \\
\text { social workers, } \\
\text { three } \\
\text { pharmacists and } \\
\text { an occupational } \\
\text { therapist. } \\
\\
\text { Setting } \\
\text { Internal } \\
\text { Medicine } \\
\text { Departments of } \\
\text { two Canadian } \\
\text { hospitals }\end{array}$ & None noted & $\begin{array}{l}\text { Independent } \\
\text { Variable: } \\
\text { Introduction of } \\
\text { smartphone } \\
\text { technology in two } \\
\text { teaching hospitals } \\
\text { Dependent } \\
\text { Variable(s) } \\
\text { Perceptions of the } \\
\text { clinicians about the } \\
\text { use and } \\
\text { satisfaction with } \\
\text { the smartphones }\end{array}$ & $\begin{array}{l}\text { Measurement } \\
\text { Open coding of } \\
\text { data. Samples } \\
\text { read by three } \\
\text { members of the } \\
\text { research team } \\
\text { independently } \\
\\
\text { Analysis } \\
\text { Conducted } \\
\text { through } \\
\text { NVivo8 } \\
\text { program. }\end{array}$ & $\begin{array}{l}\text { Positive feedback } \\
\text { included satisfaction } \\
\text { with the use of emails } \\
\text { for nonurgent issues } \\
\text { with the capability to } \\
\text { make phone calls for } \\
\text { more urgent issues. } \\
\text { Negative elements } \\
\text { included the } \\
\text { unsuitability of } \\
\text { smartphones in some } \\
\text { communication } \\
\text { contexts and the } \\
\text { negative impact of } \\
\text { discrepancies } \\
\text { between clinicians } \\
\text { with the } \\
\text { communication } \\
\text { modes }\end{array}$ & $\begin{array}{l}\text { Rating } \\
\text { Level III A/B (High/ Good quality) } \\
\text { Worth to practice } \\
\text { Robust discussion regarding the } \\
\text { benefits of technology improving } \\
\text { clinical communication in a cross- } \\
\text { section of clinicians } \\
\text { Feasibility } \\
\text { In-depth interviews provided deep } \\
\text { insight into the clinician's perspective } \\
\text { Strengths } \\
\text { Strong narrative accounts/direct quotes } \\
\text { Weaknesses, } \\
\text { Short background, thematic analysis } \\
\text { relayed only two main themes } \\
\text { Conclusion } \\
\text { Future technology interventions in } \\
\text { should take into consideration how } \\
\text { communication mediums and } \\
\text { situational contexts (e.g. urgency) } \\
\text { impact interprofessional interactions. } \\
\text { Recommendations } \\
\text { Future studies into the creation of } \\
\text { flexible communication environments } \\
\text { to mitigate the negative effects of } \\
\text { communication technologies }\end{array}$ \\
\hline
\end{tabular}




\begin{tabular}{|c|c|c|c|c|c|c|c|}
\hline $\begin{array}{l}\text { Purpose of Article } \\
\quad \text { or Review }\end{array}$ & Design/ Method & Sample/ Setting & $\begin{array}{l}\text { Conceptual } \\
\text { Framework }\end{array}$ & $\begin{array}{l}\text { Major Variables } \\
\text { Studied and their } \\
\text { Definitions) }\end{array}$ & $\begin{array}{l}\text { Measurement/ } \\
\text { Data Analysis }\end{array}$ & Findings & $\begin{array}{c}\text { Critical Appraisal Tool and Rating/ } \\
\text { Worth to Practice/ } \\
\text { Strengths and Weaknesses/ } \\
\text { Recommendations } \\
\end{array}$ \\
\hline \multicolumn{8}{|c|}{$\begin{array}{l}\text { Martin, G., Khajuria, A., Arora, S., King, D., Ashrafian, H., \& Darzi, A. (2019). The impact of mobile technology on teamwork and communication in hospitals: a systematic review. } \\
\text { Journal of the American Medical Informatics Association, 26(4), 339-355. }\end{array}$} \\
\hline $\begin{array}{l}\text { To summarize the } \\
\text { quality and breadth } \\
\text { of evidence for the } \\
\text { impact of mobile } \\
\text { technologies on } \\
\text { communication and } \\
\text { teamwork in } \\
\text { hospitals. }\end{array}$ & $\begin{array}{l}\text { Design: } \\
\text { Systematic } \\
\text { Review of } \\
\text { interventional } \\
\text { and non- } \\
\text { interventional } \\
\text { studies rated } \\
\text { from Good to } \\
\text { Poor } \\
\text { Method: } \\
\text { Electronic Data } \\
\text { base search } \\
\text { with review of } \\
\text { high vs low } \\
\text { quality studies }\end{array}$ & $\begin{array}{l}\text { Sample } \\
8,072 \text { papers } \\
\text { reviewed with } 38 \\
\text { publications } \\
\text { from } 30 \text { studies } \\
\text { included from } \\
2007-2017 \\
\\
\text { Setting } \\
\text { Search of } \\
\text { MEDLINE, } \\
\text { PsycINFO, } \\
\text { EMBASE, } \\
\text { CINAHL Plus, } \\
\text { HMIC, Cochrane } \\
\text { Library and } \\
\text { National Institute } \\
\text { of Health (NIH) } \\
\text { Research Health } \\
\text { Technology } \\
\text { Assessment }\end{array}$ & $\begin{array}{l}\text { Authors } \\
\text { followed } \\
\text { PRISMA } \\
\text { guidelines }\end{array}$ & $\begin{array}{l}\text { Independent } \\
\text { Variable: } \\
\text { Mobile } \\
\text { technologies in } \\
\text { healthcare teams } \\
\text { Dependent } \\
\text { Variable(s) } \\
\text { - communication } \\
\text { - teamwork } \\
\text { - workflow } \\
\text { efficiency, } \\
\text { - improved } \\
\text { quality of } \\
\text { communication } \\
\text { - ease of non- } \\
\text { urgent } \\
\text { communication } \\
\text { - disruption of } \\
\text { clinical } \\
\text { workflows } \\
\text { - improved team } \\
\text { relationships. }\end{array}$ & \begin{tabular}{|l} 
Measurement \\
Data \\
summarized, \\
presented in a \\
table format \\
and grouped \\
into six \\
categories \\
\\
Data Analysis \\
Two reviewers \\
independently \\
reviewed titles/ \\
abstracts for \\
eligibility \\
against \\
specified \\
inclusion and \\
exclusion \\
criteria. \\
\\
Only those \\
papers \\
considered \\
relevant \\
advanced to \\
full text review
\end{tabular} & $\begin{array}{l}\text { Observations of the } \\
\text { benefits of mobile } \\
\text { technology including } \\
\text { workflow efficiency, } \\
\text { improved quality of } \\
\text { communication, ease } \\
\text { of non-urgent } \\
\text { communications, less } \\
\text { disruption of clinical } \\
\text { workflows and } \\
\text { improved team } \\
\text { relationships. }\end{array}$ & $\begin{array}{l}\text { Rating: } \\
\text { Level II A (High quality) } \\
\text { Worth to practice } \\
\text { Valuable article providing in-depth } \\
\text { knowledge on all available levels of } \\
\text { evidence with recognition of the lack of } \\
\text { high-quality studies/evidence in this } \\
\text { field } \\
\text { Feasibility } \\
\text { Robust systematic review of } 8000+ \\
\text { articles and subsequent detailed } \\
\text { assessment of } 30 \text { studies } \\
\text { Strengths, } \\
\text { Differentiation between high- and low- } \\
\text { quality studies. Cohens Kappa used to } \\
\text { ensure interrater reliability } \\
\text { Weaknesses, } \\
\text { Limited background information given } \\
\text { in introduction section } \\
\text { Conclusion } \\
\text { The lack of high-quality evidence in the } \\
\text { area of mobility in clinical } \\
\text { communication is significant } \\
\text { Recommendation } \\
\text { Further high-quality studies on the }\end{array}$ \\
\hline
\end{tabular}




\begin{tabular}{|c|c|c|c|c|c|c|c|}
\hline $\begin{array}{l}\text { Purpose of Article } \\
\text { or Review }\end{array}$ & Design/ Method & Sample/ Setting & $\begin{array}{l}\text { Conceptual } \\
\text { Framework }\end{array}$ & $\begin{array}{l}\text { Major Variables } \\
\text { Studied and their } \\
\text { Definitions) }\end{array}$ & $\begin{array}{c}\text { Measurement/ } \\
\text { Data Analysis }\end{array}$ & Findings & $\begin{array}{c}\text { Critical Appraisal Tool and Rating } \\
\text { Worth to Practice/ } \\
\text { Strengths and Weaknesses/ } \\
\text { Recommendations } \\
\end{array}$ \\
\hline & & & & & $\begin{array}{l}\text { Cohen's kappa } \\
\text { agreement was } \\
\text { calculated for } \\
\text { each stage } \\
\text { of screening } \\
\text { and review } \\
\text { with } \\
\text { disagreements } \\
\text { resolved } \\
\text { through } \\
\text { consensus. } \\
\text { The PRISMA } \\
\text { Diagram was } \\
\text { used for study } \\
\text { inclusion } \\
\text { Key indicators } \\
\text { were quality } \\
\text { assessed } \\
\text { through the } \\
\text { NIH Quality } \\
\text { Assessment } \\
\text { Tool and the } \\
\text { World Health } \\
\text { Organizations } \\
\text { mobile health } \\
\text { evidence } \\
\text { reporting and } \\
\text { assessment } \\
\text { (mERA) } \\
\text { Checklist }\end{array}$ & & $\begin{array}{l}\text { design and implementation of mobile } \\
\text { technology to meet healthcare's needs. }\end{array}$ \\
\hline
\end{tabular}




\begin{tabular}{|c|c|c|c|c|c|c|c|}
\hline $\begin{array}{l}\text { Purpose of Article } \\
\text { or Review }\end{array}$ & Design/ Method & Sample/ Setting & $\begin{array}{c}\text { Conceptual } \\
\text { Framework }\end{array}$ & $\begin{array}{l}\text { Major Variables } \\
\text { Studied and their } \\
\text { Definitions) }\end{array}$ & $\begin{array}{l}\text { Measurement/ } \\
\text { Data Analysis }\end{array}$ & Findings & $\begin{array}{c}\text { Critical Appraisal Tool and Rating/ } \\
\text { Worth to Practice/ } \\
\text { Strengths and Weaknesses/ } \\
\text { Recommendations } \\
\end{array}$ \\
\hline \multicolumn{8}{|c|}{ Mehrzad, R., \& Barza, M. (2015). Are physician pagers an outmoded technology? Technology \& Health Care, 23(3), 233-241. } \\
\hline $\begin{array}{l}\text { To determine the } \\
\text { efficiency and } \\
\text { financial costs of } \\
\text { using pagers in } \\
\text { hospitals }\end{array}$ & $\begin{array}{l}\text { Design } \\
\text { Quantitative } \\
\text { Study } \\
\text { Method } \\
\text { Survey and } \\
\text { financial } \\
\text { analysis }\end{array}$ & $\begin{array}{l}\text { Sample } \\
\text { Seventy } \\
\text { clinicians (10 } \\
\text { attending } \\
\text { physicians, } 30 \\
\text { medical } \\
\text { residents, } 20 \\
\text { registered nurses, } \\
\text { and } 10 \text { clinical } \\
\text { pharmacists) } \\
\text { Setting } \\
\text { A community } \\
\text { hospital in } \\
\text { Boston, } \\
\text { Massachusetts. }\end{array}$ & None noted & $\begin{array}{l}\text { Independent } \\
\text { Variable: } \\
\text { Use of pagers } \\
\text { technology } \\
\text { Dependent } \\
\text { Variable(s) } \\
\text { - efficiency } \\
\text { - productivity } \\
\text { - cost } \\
\text { - perception }\end{array}$ & $\begin{array}{l}\text { Measurement } \\
\text { Survey data: } \\
\text { mean and } \\
\text { standard } \\
\text { deviation } \\
\text { analysis } \\
\text { For financial } \\
\text { data; costs } \\
\text { calculated by } \\
\text { mean time } \\
\text { spent, pages } \\
\text { sent and hourly } \\
\text { salaries. } \\
\\
\text { Data Analysis } \\
\text { No data } \\
\text { analysis tools } \\
\text { noted in the } \\
\text { paper }\end{array}$ & $\begin{array}{l}\text { The authors } \\
\text { discovered issues of } \\
\text { unproductive time by } \\
\text { physicians, nurses, } \\
\text { and pharmacists, } \\
\text { delayed ignored, or } \\
\text { missed responses as } \\
\text { well as a lack of } \\
\text { urgency around } \\
\text { paging as a } \\
\text { communication } \\
\text { method. } \\
\text { Financially, pagers } \\
\text { were found to be a } \\
\text { costly technology and } \\
\text { costly in the wasted } \\
\text { time of the clinicians. }\end{array}$ & $\begin{array}{l}\text { Rating } \\
\text { Level } 5 \text { A (financial analysis) } \\
\text { Worth to practice } \\
\text { Valuable information related to } \\
\text { inefficiencies of paging systems and } \\
\text { resulting organization financial burden } \\
\text { Feasibility } \\
\text { The extrapolation that wasted time } \\
\text { equals an actual cost saving is weak. } \\
\text { Strengths, } \\
\text { Amount of time wasted/cost of } \\
\text { technology replacement analysis is } \\
\text { strong. } \\
\text { Weaknesses, } \\
\text { No details of the survey given, appears } \\
\text { to be a survey of the number of times } \\
\text { paged during the shift } \\
\text { Conclusion } \\
\text { Pagers are inefficient and expensive } \\
\text { technology which should be replaced } \\
\text { with a direct phone calling system. }\end{array}$ \\
\hline
\end{tabular}




\begin{tabular}{|c|c|c|c|c|c|c|c|}
\hline $\begin{array}{l}\text { Purpose of Article } \\
\text { or Review }\end{array}$ & Design/Method & Sample/ Setting & $\begin{array}{l}\text { Conceptual } \\
\text { Framework }\end{array}$ & $\begin{array}{l}\text { Major Variables } \\
\text { Studied and their } \\
\text { Definitions) }\end{array}$ & $\begin{array}{l}\text { Measurement/ } \\
\text { Data Analysis }\end{array}$ & Findings & $\begin{array}{c}\text { Critical Appraisal Tool and Rating/ } \\
\text { Worth to Practice/ } \\
\text { Strengths and Weaknesses/ } \\
\text { Recommendations } \\
\end{array}$ \\
\hline \multicolumn{8}{|c|}{$\begin{array}{l}\text { Menon, R., \& Rivett C. (2019). Time-motion analysis examining of the impact of Medic Bleep, an instant messaging platform, versus the traditional pager: A prospective pilot study. } \\
\text { Digital Health, 5: 1-2. }\end{array}$} \\
\hline $\begin{array}{l}\text { To compare the use } \\
\text { of traditional pagers } \\
\text { with a pilot clinical } \\
\text { communication } \\
\text { platform consisting } \\
\text { of smart devices and } \\
\text { an instant messaging } \\
\text { application. }\end{array}$ & $\begin{array}{l}\text { Design } \\
\text { Mixed method } \\
\text { study } \\
\text { Method } \\
\text { Time and } \\
\text { motion studies, } \\
\text { interviews and } \\
\text { survey }\end{array}$ & $\begin{array}{l}\text { Setting } \\
\text { West Suffolk } \\
\text { (United } \\
\text { Kingdom) } \\
\text { National Health } \\
\text { Service Trust } \\
\text { Sample } \\
181 \text { participants } \\
\text { from three } \\
\text { clinical care } \\
\text { areas (trauma, } \\
\text { ortho and } \\
\text { maternity), } \\
\text { physician and } \\
\text { nurse over two } \\
\text { weeks with } 90 \\
\text { and } 86 \text { points of } \\
\text { interaction. }\end{array}$ & None noted & $\begin{array}{l}\text { Independent } \\
\text { Variables: } \\
\text { - smart devices } \\
\text { - instant } \\
\text { messaging } \\
\text { application } \\
\text { Dependent } \\
\text { Variable(s) } \\
\text { - task duration } \\
\text { - time savings } \\
\text { - clinician } \\
\text { perception } \\
\text { - work } \\
\text { prioritization } \\
\text { - collaboration } \\
\text { - medication } \\
\text { administration }\end{array}$ & $\begin{array}{l}\text { Measurement } \\
\text { Review of time } \\
\text { and motion } \\
\text { data, visual } \\
\text { process maps } \\
\text { well as face to } \\
\text { face interviews } \\
\text { and surveys } \\
\text { Data Analysis } \\
\text { Quantitative } \\
\text { analysis: R } \\
\text { Project for } \\
\text { Statistical } \\
\text { Computing } \\
\text { program and } \\
\text { Welch's two- } \\
\text { sample } t \text {-test. } \\
\text { Mean duration } \\
\text { analyzed } \\
\text { Visual process } \\
\text { mapping } \\
\text { conducted }\end{array}$ & $\begin{array}{l}\text { A statistically } \\
\text { significant reduction } \\
(\mathrm{p}<0.05) \text { in task- } \\
\text { duration and time } \\
\text { saved per shift ( } \mathrm{p}< \\
\text { 0.05) was noted. } \\
\text { A perceived benefit } \\
\text { from the team on } \\
\text { work prioritization, } \\
\text { collaboration and } \\
\text { medication } \\
\text { administration. } \\
\text { Results of the task } \\
\text { duration analysis was } \\
\text { demonstrated on a } \\
\text { Kernel density plot } \\
\text { diagram }\end{array}$ & $\begin{array}{l}\text { Rating } \\
\text { Level III A/ B (High/ Good Quality) } \\
\text { Worth to practice } \\
\text { This study definitively demonstrates } \\
\text { the value of clinical communication } \\
\text { technology both quantitively and } \\
\text { qualitatively. } \\
\text { Feasibility } \\
\text { Strong- time and motion studies with } \\
\text { observers, and the qualitative elements } \\
\text { make this a highly feasible result } \\
\text { Strengths, } \\
\text { Observers for time and motion studies. } \\
\text { Robust analysis of quantitative data } \\
\text { Weaknesses, } \\
\text { No details of qualitative data analysis } \\
\text { that resulted in their conclusions. } \\
\text { Conclusion } \\
\text { There was a positive effect on task } \\
\text { duration, efficiency and work } \\
\text { environment but the authors state there } \\
\text { is a need to replicate this study with a } \\
\text { wider sample of participants } \\
\text { Recommendation } \\
\text { Further studies on a larger sample size } \\
\text { over a longer duration in more areas of } \\
\text { the hospital setting }\end{array}$ \\
\hline
\end{tabular}




\begin{tabular}{|c|c|c|c|c|c|c|c|}
\hline $\begin{array}{l}\text { Purpose of Article } \\
\text { or Review }\end{array}$ & Design/ Method & Sample/ Setting & $\begin{array}{l}\text { Conceptual } \\
\text { Framework }\end{array}$ & $\begin{array}{l}\text { Major Variables } \\
\text { Studied and their } \\
\text { Definitions) }\end{array}$ & $\begin{array}{l}\text { Measurement/ } \\
\text { Data Analysis }\end{array}$ & Findings & $\begin{array}{c}\text { Critical Appraisal Tool and Rating/ } \\
\text { Worth to Practice/ } \\
\text { Strengths and Weaknesses/ } \\
\text { Recommendations } \\
\end{array}$ \\
\hline \multicolumn{8}{|c|}{$\begin{array}{l}\text { Mickan, S., Atherton, H., Roberts, N.W., Heneghan, C., \& Tilson, J. (2014). Use of handheld computers in clinical practice: a systematic review. BMC Medical Informatics and } \\
\text { Decision Making, 14:56. }\end{array}$} \\
\hline $\begin{array}{l}\text { To examine if } \\
\text { smartphone and } \\
\text { tablet use in the } \\
\text { healthcare team } \\
\text { improves team } \\
\text { access to } \\
\text { information and } \\
\text { supports clinical } \\
\text { decision making }\end{array}$ & $\begin{array}{l}\text { Design } \\
\text { Systematic } \\
\text { review of } \\
\text { Randomized } \\
\text { Control Trials } \\
\text { (RCTs) only } \\
\text { Method } \\
\text { Detailed } \\
\text { database search } \\
\text { from } 2001 \text { to } \\
2013\end{array}$ & $\begin{array}{l}\text { Sample } \\
3612 \text { papers } \\
\text { reviewed with } 38 \\
\text { read, of which } \\
\text { only seven met } \\
\text { with inclusion } \\
\text { criteria } \\
\\
\text { Setting } \\
\text { Search of } \\
\text { Cochrane } \\
\text { Central Register } \\
\text { of Controlled } \\
\text { Trials } \\
\text { (CENTRAL), } \\
\text { MEDLINE, } \\
\text { PsycINFO, } \\
\text { EMBASE, } \\
\text { Science Citation } \\
\text { Index and Social } \\
\text { Science Citation } \\
\text { Index }\end{array}$ & None & $\begin{array}{l}\text { Independent } \\
\text { Variable: } \\
\text { Use of } \\
\text { smartphones and } \\
\text { tables in healthcare } \\
\text { Dependent } \\
\text { Variable(s) } \\
\text { - improvement in } \\
\text { team access to } \\
\text { information } \\
\text { - support for } \\
\text { clinical decision } \\
\text { making }\end{array}$ & $\begin{array}{l}\text { Measurement } \\
\text { Narrative } \\
\text { approach to } \\
\text { summarize } \\
\text { evidence for } \\
\text { effectiveness } \\
\\
\text { Data Analysis } \\
\text { The authors } \\
\text { noted that } \\
\text { "high levels of } \\
\text { data } \\
\text { heterogeneity } \\
\text { and mixed data } \\
\text { quality meant } \\
\text { that statistical } \\
\text { synthesis was } \\
\text { not possible", } \\
\text { however, some } \\
\text { statistical } \\
\text { significance } \\
\text { was noted. }\end{array}$ & $\begin{array}{l}\text { There is statistically } \\
\text { significant proof }(\mathrm{p}< \\
0.05 \text { and } \mathrm{p}<0.01) \\
\text { that handheld } \\
\text { computers made } \\
\text { synthetized } \\
\text { information more } \\
\text { available to clinicians } \\
\text { and that this has the } \\
\text { potential to improve } \\
\text { clinical decision- } \\
\text { making at the bedside }\end{array}$ & $\begin{array}{l}\text { Rating } \\
\text { Level I A (High quality) as it is a } \\
\text { systematic review of RCTs. } \\
\text { Worth to practice } \\
\text { Valuable information from the early } \\
\text { use of handheld devices about their } \\
\text { application to healthcare settings } \\
\text { Feasibility } \\
\text { Strong search methodology and review } \\
\text { process with interrater reliability noted. } \\
\text { Strengths } \\
\text { Review of highest available level of } \\
\text { evidence in the topic. Detailed analysis. } \\
\text { Weaknesses, } \\
\text { Only available studies were on the use } \\
\text { of PDAs - not smartphones/tablets } \\
\text { Conclusion } \\
\text { The authors recommended further } \\
\text { studies to determine if there are direct } \\
\text { improvements in clinical outcomes and } \\
\text { to review the conditions in which } \\
\text { handheld computers have their best } \\
\text { results. } \\
\text { Recommendations } \\
\text { Conduct current (2020) systematic } \\
\text { review of RCTs to add smartphones } \\
\text { and tablets }\end{array}$ \\
\hline
\end{tabular}




\begin{tabular}{|c|c|c|c|c|c|c|c|}
\hline $\begin{array}{l}\text { Purpose of Article } \\
\text { or Review }\end{array}$ & Design/Method & Sample/ Setting & $\begin{array}{l}\text { Conceptual } \\
\text { Framework }\end{array}$ & $\begin{array}{l}\text { Major Variables } \\
\text { Studied and their } \\
\text { Definitions) }\end{array}$ & $\begin{array}{l}\text { Measurement/ } \\
\text { Data Analysis }\end{array}$ & Findings & $\begin{array}{c}\text { Critical Appraisal Tool and Rating/ } \\
\text { Worth to Practice/ } \\
\text { Strengths and Weaknesses/ } \\
\text { Recommendations } \\
\end{array}$ \\
\hline \multicolumn{8}{|c|}{$\begin{array}{l}\text { Motulsky, A., Wong, J., Cordeau, J.-P., Pomalaza, J., Barkun, J., Tamblyn, R., \& Wong, J. (2017). Using mobile devices for inpatient rounding and handoffs: an innovative application } \\
\text { developed and rapidly adopted by clinicians in a pediatric hospital. Journal of the American Medical Informatics Association, 24(e1), e69-e78. }\end{array}$} \\
\hline $\begin{array}{l}\text { To describe the } \\
\text { usage patterns and } \\
\text { end-user satisfaction } \\
\text { of a new application } \\
\text { (handoff and } \\
\text { rounding tool) as a } \\
\text { mobile technology } \\
\text { solution }\end{array}$ & $\begin{array}{l}\text { Design } \\
\text { Quantitative } \\
\text { Survey } \\
\text { Method } \\
\text { Questionnaire } \\
\text { to describe user } \\
\text { experience }\end{array}$ & $\begin{array}{l}\text { Sample } \\
127 \text { survey } \\
\text { responses } \\
\text { Setting } \\
\text { Pediatric and } \\
\text { Neonatal } \\
\text { Intensive Care } \\
\text { (PICU and } \\
\text { NICU) Units in } \\
\text { McGill } \\
\text { University in } \\
\text { Montreal, } \\
\text { Canada }\end{array}$ & $\begin{array}{l}\text { Davis's } \\
\text { Technology } \\
\text { Acceptance } \\
\text { Model }\end{array}$ & $\begin{array}{l}\text { Independent } \\
\text { Variable: } \\
\text { Implementation of } \\
\text { an electronic } \\
\text { Handoff and } \\
\text { rounding tool } \\
\text { Dependent } \\
\text { Variable(s) } \\
\text { - usage after one } \\
\quad \text { year } \\
\text { - end user } \\
\quad \text { satisfaction }\end{array}$ & $\begin{array}{l}\text { Measurement } \\
\text { Usage patterns } \\
\text { assessed using } \\
\text { the Kruskal } \\
\text { Wallis Test. } \\
\text { Differences } \\
\text { assessed using } \\
\text { Wilcoxon } \\
\text { Rank sum test. } \\
\text { Data Analysis } \\
\text { All analysis } \\
\text { was conducted } \\
\text { in SAS } 9.4 \text { and } \\
\text { Gephi } 0.8 .2 \\
\text { beta. }\end{array}$ & $\begin{array}{l}\text { The authors found } \\
\text { that the ICUs } \\
\text { continued to use the } \\
\text { application (app) one } \\
\text { year after } \\
\text { implementation, but } \\
\text { the medical-surgical } \\
\text { departments stopped } \\
\text { after six months due } \\
\text { to a lack of } \\
\text { functionality for their } \\
\text { workflows. Most } \\
\text { physician and 'some } \\
\text { nurse' participants } \\
\text { wanted to keep using } \\
\text { the app after } \\
\text { implementation. } \\
\text { On average, } \\
\text { respondents were } \\
\text { positive in their } \\
\text { perceptions about the } \\
\text { usability and impact } \\
\text { of the application }\end{array}$ & $\begin{array}{l}\text { Rating } \\
\text { Level III A/B (Good/High quality) } \\
\text { (non-experimental study) } \\
\text { Worth to practice } \\
\text { Useful article to determine the value of } \\
\text { clinician specific applications on } \\
\text { mobile devices } \\
\text { Feasibility } \\
\text { Moderate given the non-users were not } \\
\text { surveyed. } \\
\text { Strengths } \\
\text { Data analysis and presentation was } \\
\text { very strong in this article } \\
\text { The survey questions were } \\
\text { demonstrated in the article } \\
\text { Weaknesses, } \\
\text { No viewpoint from clinicians who } \\
\text { abandoned the application } \\
\text { Conclusion } \\
\text { Usage varied by clinician group } \\
\text { identified and a gap in the authors' data } \\
\text { collection was identified based on the } \\
\text { weakness above. } \\
\text { Recommendations } \\
\text { Studying the users who abandoned the } \\
\text { app for their rationale and study of the } \\
\text { different usage patterns in different } \\
\text { units reflect different team-based work } \\
\text { practices. }\end{array}$ \\
\hline
\end{tabular}




\begin{tabular}{|c|c|c|c|c|c|c|c|}
\hline $\begin{array}{l}\text { Purpose of Article } \\
\text { or Review }\end{array}$ & Design/ Method & Sample/ Setting & $\begin{array}{l}\text { Conceptual } \\
\text { Framework }\end{array}$ & $\begin{array}{l}\text { Major Variables } \\
\text { Studied and their } \\
\text { Definitions) }\end{array}$ & $\begin{array}{l}\text { Measurement/ } \\
\text { Data Analysis }\end{array}$ & Findings & $\begin{array}{c}\text { Critical Appraisal Tool and Rating/ } \\
\text { Worth to Practice/ } \\
\text { Strengths and Weaknesses/ } \\
\text { Recommendations } \\
\end{array}$ \\
\hline \multicolumn{8}{|c|}{$\begin{array}{l}\text { Patel, N., Siegler, J., Stromberg, N., Ravitz, N., \& Hanson, C. (2016). Perfect storm of inpatient communication needs and an innovative solution utilizing smartphones and secured } \\
\text { messaging. Applied Clinical Informatics, 7: 777-789. }\end{array}$} \\
\hline $\begin{array}{l}\text { To confirm the } \\
\text { authors' hypothesis } \\
\text { that a mobile device } \\
\text { with a secure } \\
\text { messaging } \\
\text { application would } \\
\text { be an efficient and } \\
\text { effective mode for } \\
\text { non-urgent } \\
\text { communication and } \\
\text { care team co- } \\
\text { ordination }\end{array}$ & $\begin{array}{l}\text { Design } \\
\text { Quantitative } \\
\text { study } \\
\text { Method } \\
\text { Pre- and post- } \\
\text { survey } \\
\text { evaluations of a } \\
\text { secure } \\
\text { messaging } \\
\text { application }\end{array}$ & $\begin{array}{l}\text { Sample } \\
\text { Pre- } 136 \text { nurses } \\
\text { and } 93 \\
\text { physicians } \\
\text { Post- } 127 \text { nurses } \\
\text { and } 83 \\
\text { physicians } \\
\text { Setting } \\
\text { Four hospital } \\
\text { units over a one- } \\
\text { year period at the } \\
\text { Hospital of } \\
\text { University of } \\
\text { Pennsylvania }\end{array}$ & None noted & \begin{tabular}{l} 
Independent \\
Variable: \\
The introduction of \\
a mobile device \\
with a secure \\
messaging \\
application \\
Dependent \\
Variable(s)\} $\\
{\text { - efficiency }} \\
{\text { - effectiveness as a }} \\
{\text { mode for non- }} \\
{\text { urgent }} \\
{\text { communication }} \\
{\text { and care team }} \\
{\text { co-ordination }} \\
{\text { - disruptions }}$ & \begin{tabular}{|l} 
Measurement \\
Device and \\
application \\
usage as well \\
as pre and post \\
implementatio \\
n survey \\
Data analysis \\
Usage - \\
data analyzed \\
using \\
descriptive \\
statistics and \\
the Kruskal- \\
Wallis test, \\
where \\
appropriate. \\
\\
Survey - \\
responses \\
compared \\
using Mann \\
Whitney U \\
test. Analysis \\
conducted in \\
STATA \\
version 14.0
\end{tabular} & $\begin{array}{l}\text { Data Usage: Over } \\
\text { half the messages } \\
\text { sent to resident } \\
\text { physicians after } \\
\text { implementation were } \\
\text { read within one } \\
\text { minute. } \\
\text { Survey: Both } \\
\text { physicians and nurses } \\
\text { demonstrated } \\
\text { statistically } \\
\text { significant less } \\
\text { disruptions to their } \\
\text { workflows. } \\
\text { Physicians felt they } \\
\text { received more } \\
\text { complete information } \\
\text { over the messaging } \\
\text { app. }\end{array}$ & $\begin{array}{l}\text { Rating } \\
\text { Level III A/B (good/high quality) } \\
\text { Worth to practice } \\
\text { Valuable information about clinician } \\
\text { usage and perceptions of mobile } \\
\text { devices and secure messaging apps. } \\
\text { Feasibility } \\
\text { Strong implications in facilities seeking } \\
\text { to implement secure messaging apps } \\
\text { Strengths, } \\
\text { Usage data as well as end user } \\
\text { perceptions were assessed/ described in } \\
\text { complete detail with each element rated } \\
\text { for its statistical significance } \\
\text { Weaknesses, } \\
\text { Authors did not study content of } \\
\text { messages (for urgency). Poor Wi-Fi } \\
\text { connection post implementation may } \\
\text { have affected survey results. } \\
\text { Conclusions } \\
\text { The authors discussed the issue of } \\
\text { sustainability, a factor they felt was } \\
\text { assisted by the rising use of } \\
\text { smartphones in non-work life. } \\
\text { Recommendation } \\
\text { Enlarging the study to other areas of } \\
\text { the hospital and determine if there were } \\
\text { positive effects on patient outcomes. }\end{array}$ \\
\hline
\end{tabular}
\end{tabular}




\begin{tabular}{|c|c|c|c|c|c|c|c|}
\hline $\begin{array}{l}\text { Purpose of Article } \\
\text { or Review }\end{array}$ & Design/ Method & Sample/ Setting & $\begin{array}{l}\text { Conceptual } \\
\text { Framework }\end{array}$ & $\begin{array}{l}\text { Major Variables } \\
\text { Studied and their } \\
\text { Definitions) }\end{array}$ & $\begin{array}{l}\text { Measurement/ } \\
\text { Data Analysis }\end{array}$ & Findings & $\begin{array}{c}\text { Critical Appraisal Tool and Rating/ } \\
\text { Worth to Practice/ } \\
\text { Strengths and Weaknesses/ } \\
\text { Recommendations } \\
\end{array}$ \\
\hline \multicolumn{8}{|c|}{ VanDusen, K. (2017). Calling on smartphones to enhance patient care, Nursing2017. } \\
\hline $\begin{array}{l}\text { This nursing article } \\
\text { is a short summary } \\
\text { of the advantages of } \\
\text { smartphones in } \\
\text { healthcare and a } \\
\text { reminder of the } \\
\text { pitfalls to avoid } \\
\text { when implementing } \\
\text { smartphone } \\
\text { technology. There } \\
\text { was no hypothesis } \\
\text { or formal research } \\
\text { associated with the } \\
\text { article. }\end{array}$ & $\begin{array}{l}\text { Expert opinion- } \\
\text { no design or } \\
\text { methodology }\end{array}$ & Not applicable & None noted & $\begin{array}{l}\text { Independent } \\
\text { Variable: } \\
\text { Not applicable } \\
\text { Dependent } \\
\text { Variable(s) } \\
\text { Not applicable }\end{array}$ & \begin{tabular}{|l} 
Expert \\
opinion- no \\
data analysis
\end{tabular} & $\begin{array}{l}\text { The author highlights } \\
\text { the benefits of } \\
\text { smartphones } \\
\text { including efficiency, } \\
\text { effectiveness, } \\
\text { improved emergency } \\
\text { response time and } \\
\text { increased frequency } \\
\text { of provider responses } \\
\text { to nurses. Pitfalls of } \\
\text { this technology can } \\
\text { be seen in the areas } \\
\text { of confidentiality, } \\
\text { destroying data, } \\
\text { additional } \\
\text { interruption that } \\
\text { divides a clinician's } \\
\text { attention, and poor } \\
\text { staff relations } \\
\text { because of the } \\
\text { technology. }\end{array}$ & $\begin{array}{l}\text { Rating } \\
\text { Level V B (good quality) } \\
\text { Worth to practice } \\
\text { Valuable short article specifically } \\
\text { introduces the nurses voice to the } \\
\text { discussion. } \\
\text { Feasibility } \\
\text { Feasible as the opinion of an expert at } \\
\text { the bedside } \\
\text { Strengths, } \\
\text { Expert opinion from a frontline nurse, } \\
\text { recommendations for future } \\
\text { implementations from the frontline } \\
\text { perspective. Strong references to } \\
\text { support the authors opinion } \\
\text { Weaknesses, } \\
\text { No actual study of interventions. } \\
\text { Conclusion } \\
\text { Smartphone technology benefits } \\
\text { clinicians in many areas but has } \\
\text { multiple pitfalls. } \\
\text { Recommendations: } \\
\text { Engage staff to reduce medical errors } \\
\text { through improved communication and } \\
\text { identification of issues. Ensure } \\
\text { implementation teams provide adequate } \\
\text { training that focuses on team building } \\
\text { efforts and communication protocols. }\end{array}$ \\
\hline
\end{tabular}




\begin{tabular}{|c|c|c|c|c|c|c|c|}
\hline $\begin{array}{l}\text { Purpose of Article } \\
\text { or Review }\end{array}$ & Design/ Method & Sample/ Setting & $\begin{array}{l}\text { Conceptual } \\
\text { Framework }\end{array}$ & $\begin{array}{l}\text { Major Variables } \\
\text { Studied and their } \\
\text { Definitions) }\end{array}$ & $\begin{array}{l}\text { Measurement/ } \\
\text { Data Analysis }\end{array}$ & Findings & $\begin{array}{c}\text { Critical Appraisal Tool and Rating/ } \\
\text { Worth to Practice/ } \\
\text { Strengths and Weaknesses/ } \\
\text { Recommendations } \\
\end{array}$ \\
\hline \multicolumn{8}{|c|}{$\begin{array}{l}\text { Whitlow, M., Drake, E., Tullman, D., Hoke, G., \& Barth, D. (2014). Bringing technology to the bedside using smartphones to improve interprofessional communication. CIN: } \\
\text { Computers, Informatics, Nursing,32, No. 7, 305-311. }\end{array}$} \\
\hline $\begin{array}{l}\text { To describe a } \\
\text { quality improvement } \\
\text { project where } \\
\text { smartphone } \\
\text { technology was } \\
\text { implemented }\end{array}$ & $\begin{array}{l}\text { Design } \\
\text { Quality } \\
\text { Improvement } \\
\text { project } \\
\text { Method } \\
\text { Survey and time } \\
\text { and motion } \\
\text { studies }\end{array}$ & $\begin{array}{l}\text { Sample } \\
61 \text { nurses and } 44 \\
\text { physicians } \\
\text { Setting } \\
\text { Nurses and } \\
\text { Physicians in a } \\
\text { med/surg unit in } \\
\text { the University of } \\
\text { Virginia Health } \\
\text { System }\end{array}$ & $\begin{array}{l}\text { The } \\
\text { Donabedian } \\
\text { Model on } \\
\text { Patient } \\
\text { Safety and } \\
\text { The Delone } \\
\text { and McLean } \\
\text { Information } \\
\text { Systems } \\
\text { Success } \\
\text { Model }\end{array}$ & $\begin{array}{l}\text { Independent } \\
\text { Variable: } \\
\text { the impact of using } \\
\text { Smartphones at the } \\
\text { bedside compared } \\
\text { to pagers } \\
\text { Dependent } \\
\text { Variable(s)c } \\
\text { - the quality of } \\
\text { interprofessional } \\
\text { communication } \\
\text { - the response time } \\
\text { between nurses } \\
\text { and physicians }\end{array}$ & $\begin{array}{l}\text { Measurement } \\
\text { Quantitative: } \\
\text { differences } \\
\text { assessed using } \\
\text { Wilcoxen } \\
\text { signed-rank } \\
\text { test. } \\
\text { Data Analysis } \\
\text { SPSS version } \\
20 \text { used for } \\
\text { statistical } \\
\text { analysis. }\end{array}$ & $\begin{array}{l}\text { The findings of the } \\
\text { project were that } \\
\text { smartphones } \\
\text { demonstrated nurse } \\
\text { and physician time } \\
\text { savings, improved } \\
\text { workflows, increased } \\
\text { nurse-physician } \\
\text { collaboration and } \\
\text { allowed more time to } \\
\text { be spent with the } \\
\text { patient. }\end{array}$ & $\begin{array}{l}\text { Rating: Level V-A } \\
\text { Note: While there was statistically } \\
\text { significant and robust analysis of } \\
\text { quantitative data, the authors labeled } \\
\text { this study as a Quality Improvement } \\
\text { project. Therefore, its rating is Level V } \\
\text { A under 'Organizational Experience' } \\
\text { Worth to practice } \\
\text { Valuable information on improvements } \\
\text { mobile devices can bring to clinicians. } \\
\text { Feasibility } \\
\text { Strong work in the form of both a time } \\
\text { and motion study and a survey } \\
\text { Strengths, } \\
\text { Robust analysis of both time and } \\
\text { motion studies and survey responses. } \\
\text { Statistically significant results } \\
\text { Weaknesses, } \\
\text { Physician reluctance to participate fully } \\
\text { may have had a negative effect } \\
\text { Conclusion } \\
\text { Project demonstrated the feasibility and } \\
\text { positive impact that smartphones have } \\
\text { on communication response times. } \\
\text { Recommendation } \\
\text { Further research on the impact of } \\
\text { smartphone technology on patient } \\
\text { satisfaction and safety and cost savings. }\end{array}$ \\
\hline
\end{tabular}




\section{Appendix H}

\section{Capabilities of a Fully Integrated CC\&C Platform}

\begin{tabular}{|c|c|}
\hline Category & Functionality \\
\hline $\begin{array}{l}\text { Clinical } \\
\text { Communication }\end{array}$ & $\begin{array}{l}\text { - Streamlined communication on a single mobile (hands-free or hand- } \\
\text { held) device with a convergence of voice, secure messaging, video } \\
\text { calls, and event management } \\
\text { - Synchronous and asynchronous communication options } \\
\text { - HIPAA compliance } \\
\text { - Individual or group calls/messaging } \\
\text { - Role-based clinical directory by department, team, or role (e.g., } \\
\text { - call ICU Respiratory Therapist") } \\
\text { - Staff location awareness } \\
\text { - Push notifications (e.g., lab results) }\end{array}$ \\
\hline $\begin{array}{l}\text { EMR and Patient } \\
\text { Monitoring }\end{array}$ & $\begin{array}{l}\text { - } \text { Real-time mobile access to patient information } \\
\text { - } \quad \text { Flowsheet and notes documentation } \\
\text { - Image capture } \\
\text { - } \quad \text { Barcode medication administration (BCMA) }\end{array}$ \\
\hline $\begin{array}{l}\text { Clinical } \\
\text { Efficiency }\end{array}$ & $\begin{array}{l}\text { - } \text { Clinical on-call schedules } \\
\text { - Ability to see who is on duty in real time } \\
\text { - Alarms for upcoming events } \\
\text { - Share urgent information }\end{array}$ \\
\hline $\begin{array}{l}\text { Alarm/Alert } \\
\text { Management }\end{array}$ & $\begin{array}{l}\text { - View cardiac rhythms } \\
\text { - Receive cardiac alarms stratified by event criticality } \\
\text { - Intelligent alarms/alert escalation if no response received } \\
\text { - Patient call/bed alarm notifications }\end{array}$ \\
\hline $\begin{array}{l}\text { Workflow } \\
\text { Efficiency }\end{array}$ & $\begin{array}{ll}\text { - } & \text { Mobility (prevents waiting for calls at a desk) } \\
\text { - } & \text { Transmission of administrative/urgent messages } \\
\text { - } & \text { Workplace rules/guidelines information } \\
\text { - } & \text { Handoff/ rounding tools } \\
\text { - } & \text { Faster staff response times }\end{array}$ \\
\hline $\begin{array}{l}\text { Information } \\
\text { Availability }\end{array}$ & $\begin{array}{l}\text { - } \text { Clinical practice, quality and safety guidelines access } \\
\text { - View policies/procedures } \\
\text { - View reference material e.g. Micromedex } \\
\text { - Access to work email }\end{array}$ \\
\hline
\end{tabular}

Adapted from Redelmeier and Detsky (2013), with permission (personal communication, September 2019) 


\section{Appendix I}

\section{Gap Analysis}

\begin{tabular}{|c|c|c|c|c|}
\hline $\begin{array}{c}\text { Clinical } \\
\text { Communication } \\
\text { Focus Area } \\
\end{array}$ & Current State & Desired Future State & Identified Gap & Action Plan \\
\hline Focus area & Where are you now? & Where would you like to be? & Impact to the organization & Projects to undertake \\
\hline $\begin{array}{l}\text { Health System } \\
\text { Level }\end{array}$ & $\begin{array}{l}\text { Six of } 39 \text { hospitals with } \\
\text { smartphone technology. } \\
33 \text { of } 39 \text { hospitals still } \\
\text { have older analog } \\
\text { phones. } \\
\text { Multiple different } \\
\text { technologies requiring } \\
\text { multiple departments to } \\
\text { manage interoperability. }\end{array}$ & $\begin{array}{l}\text { All facilities would be on the } \\
\text { same clinical communication } \\
\text { platform, which will improve } \\
\text { quality, safety, clinician, and } \\
\text { staff satisfaction, as well as } \\
\text { financially assisting the } \\
\text { organization to streamline } \\
\text { technology into one product. }\end{array}$ & $\begin{array}{l}\text { Multiple different ways to } \\
\text { communicate between } \\
\text { clinicians with resultant } \\
\text { confusion, potential for } \\
\text { organizational risk, and } \\
\text { safety issues. } \\
\text { Cost of maintaining } \\
\text { multiple technologies. }\end{array}$ & $\begin{array}{l}\text { Prepare an IT and } \\
\text { clinical business case at } \\
\text { the national KP level to } \\
\text { determine the clinical } \\
\text { and financial return on } \\
\text { investment (ROI) for } \\
\text { implementing a system } \\
\text { like this. } \\
\text { Collect data at the } \\
\text { Southern California } \\
\text { project site before and } \\
\text { after go-live to inform } \\
\text { the business case. }\end{array}$ \\
\hline Facility Level & $\begin{array}{l}\text { Physicians have iPhones } \\
\text { and pagers and use } \\
\text { Cortext for messaging } \\
\text { with physicians. } \\
\text { Nurses have Cisco } \\
\text { phones. } \\
\text { Pharmacy and ward } \\
\text { clerks use desk phones to } \\
\text { page physicians and to }\end{array}$ & $\begin{array}{l}\text { All clinicians are on the same } \\
\text { platform and communications } \\
\text { are synchronous when needed } \\
\text { (timely) and asynchronous } \\
\text { when less urgent. There is no } \\
\text { time wasted during clinical } \\
\text { communication. }\end{array}$ & $\begin{array}{l}\text { Patient safety and quality } \\
\text { are risked by having poor } \\
\text { communication } \\
\text { methodologies. } \\
\text { Reputation of the } \\
\text { organization and ability to } \\
\text { hire clinicians may be at } \\
\text { risk from fragmented } \\
\text { clinical communication. }\end{array}$ & $\begin{array}{l}\text { Implement a unified } \\
\text { clinical communication } \\
\text { platform that is more } \\
\text { efficient and streamlined } \\
\text { for all clinicians and the } \\
\text { care team. }\end{array}$ \\
\hline
\end{tabular}




\begin{tabular}{|c|c|c|c|c|}
\hline $\begin{array}{c}\text { Clinical } \\
\text { Communication } \\
\text { Focus Area }\end{array}$ & Current State & Desired Future State & Identified Gap & Action Plan \\
\hline & $\begin{array}{l}\text { call nurses' Cisco } \\
\text { phones. }\end{array}$ & & & \\
\hline Clinician Level & $\begin{array}{l}\text { Multiple communication } \\
\text { methodologies to } \\
\text { collaborate, including } \\
\text { paging, direct calling, } \\
\text { waiting. } \\
\text { There is frustration with } \\
\text { poor communication } \\
\text { when clinicians are not in } \\
\text { the same location. }\end{array}$ & $\begin{array}{l}\text { All clinicians are on the same } \\
\text { platform, improving the } \\
\text { quality of care. } \\
\text { Collaboration improves. }\end{array}$ & $\begin{array}{l}\text { Clinicians are using } \\
\text { multiple communication } \\
\text { methodologies, which } \\
\text { wastes time and causes } \\
\text { frustration, as well as risks } \\
\text { quality and patient safety. }\end{array}$ & $\begin{array}{l}\text { Implement a unified } \\
\text { clinical communication } \\
\text { platform that is more } \\
\text { efficient and streamlined } \\
\text { for all clinicians and the } \\
\text { care team. }\end{array}$ \\
\hline $\begin{array}{l}\text { Implementation } \\
\text { Gap }\end{array}$ & $\begin{array}{l}\text { No formal clinical } \\
\text { implementation guide to } \\
\text { assist the facility in } \\
\text { preparation for the go- } \\
\text { live of the technology. }\end{array}$ & $\begin{array}{l}\text { An implementation guide is } \\
\text { developed to assist clinical } \\
\text { facility leadership in } \\
\text { preparation for future go- } \\
\text { lives. }\end{array}$ & $\begin{array}{l}\text { No implementation guide } \\
\text { is in place to fully prepare } \\
\text { the facility or clinicians for } \\
\text { the future state. } \\
\text { No clinical project lead is } \\
\text { identified to champion the } \\
\text { change. }\end{array}$ & $\begin{array}{l}\text { Prepare an } \\
\text { implementation guide } \\
\text { for future go-lives and } \\
\text { test that guide with } \\
\text { currently live facilities. }\end{array}$ \\
\hline
\end{tabular}




\section{Appendix J}

\section{Gantt Chart (Project Only)}

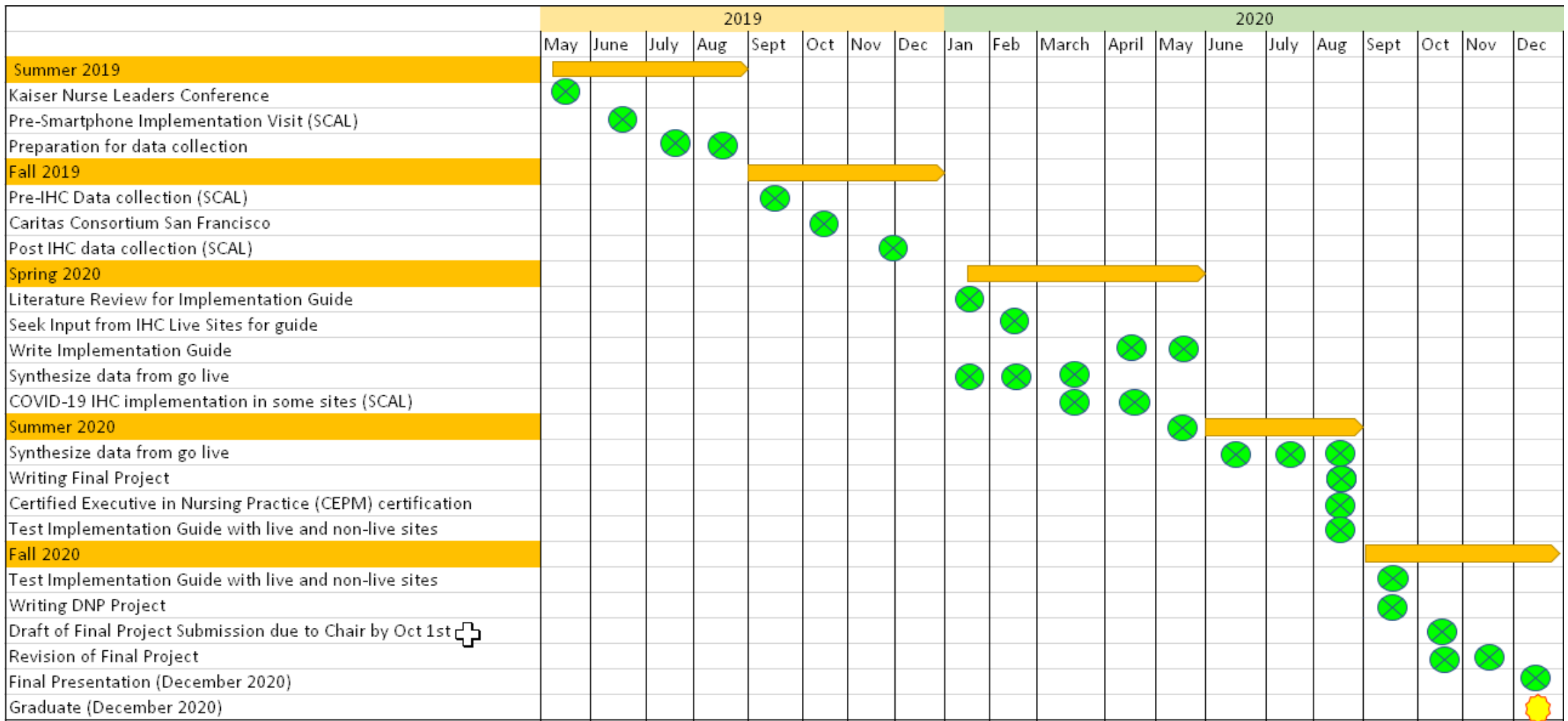




\section{Appendix K}

\section{Work Breakdown Structure}

L1: Implement a unified clinical communication platform in a multi-hospital system

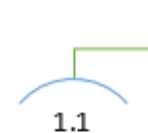

1.1

Create Business Case

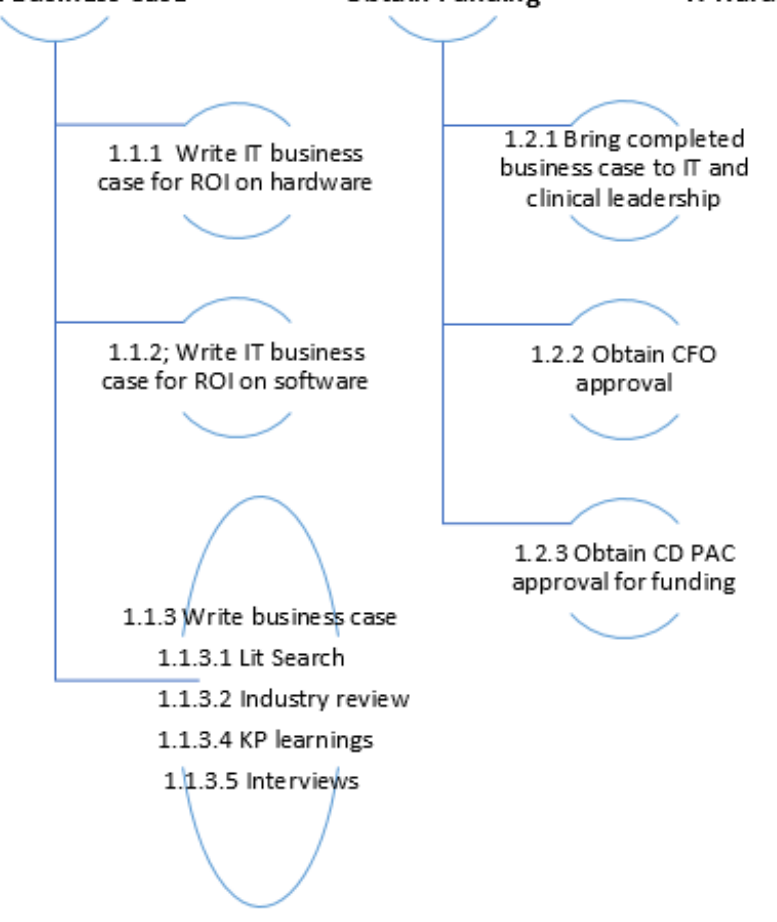

1.3 $+1$

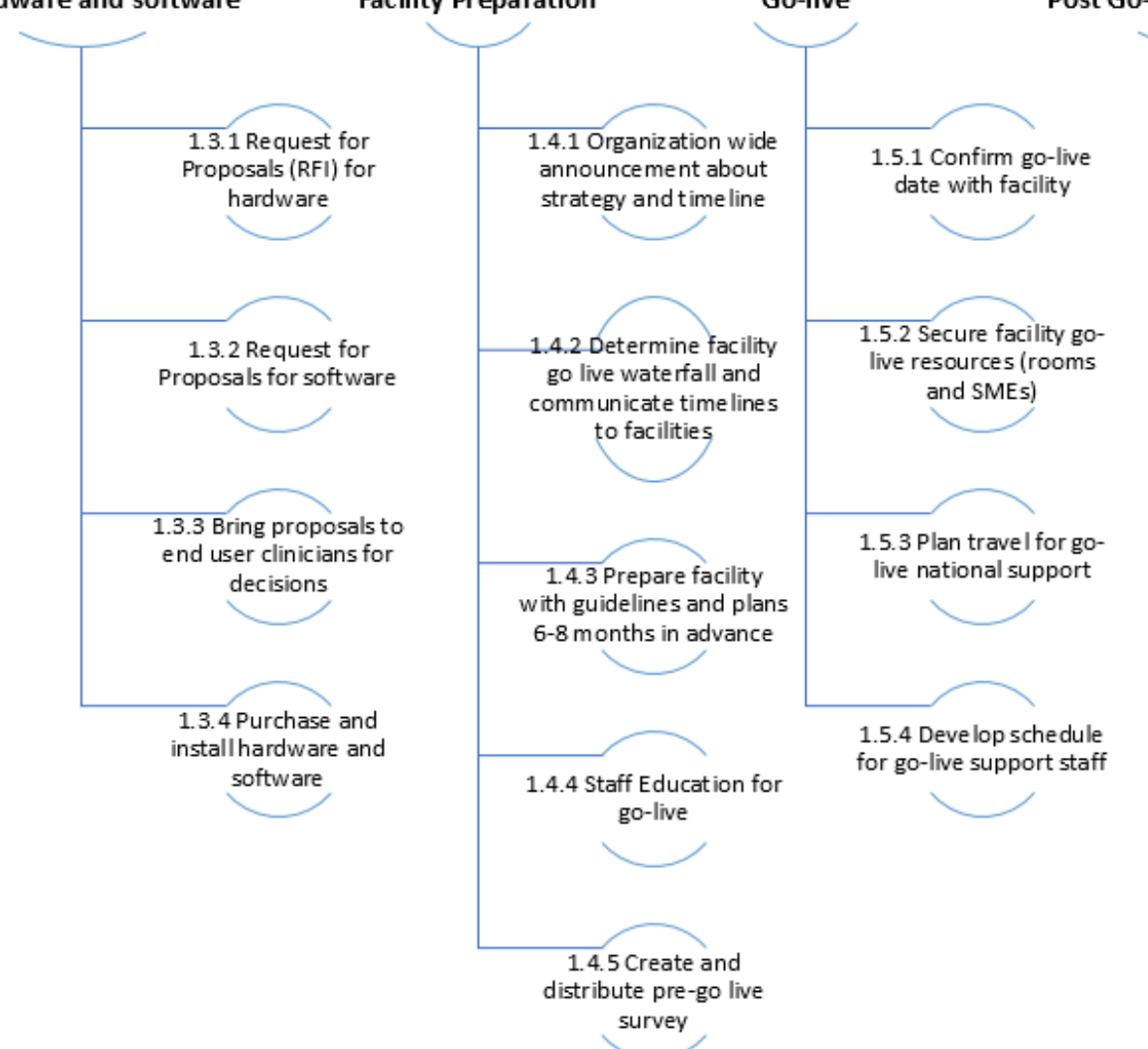
1.6 
L1: Create an Implementation guide for a unified clinical communication platform in a multi-hospital system

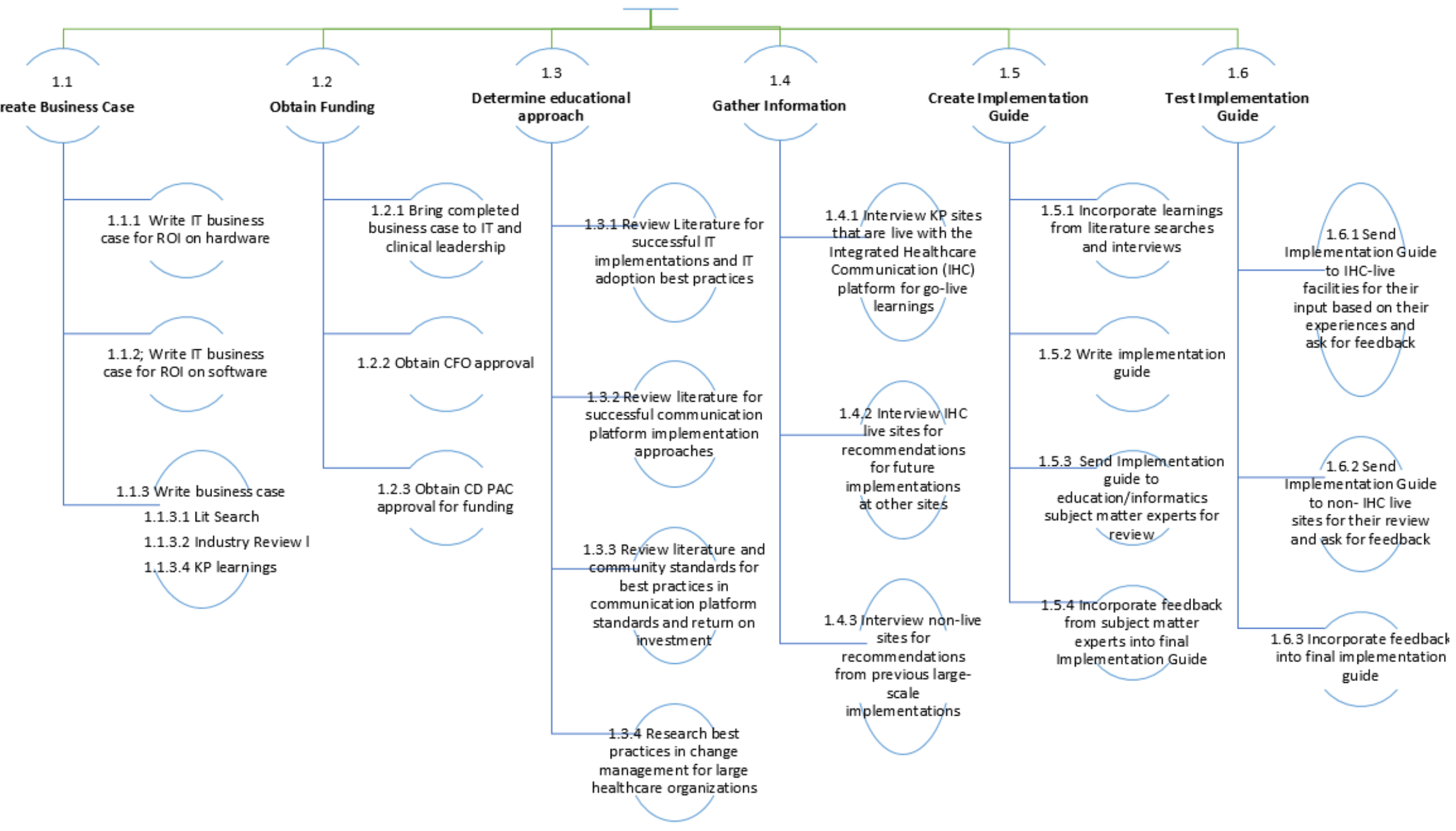




\section{Appendix L}

\section{SWOT Analysis}

Strengths, Weaknesses, Opportunities, Threats (SWOT) Analysis - Facility Level

\begin{tabular}{|c|c|c|}
\hline & Helpful to Achieve the Objective & Harmful to Achieve the Objective \\
\hline 窇 & 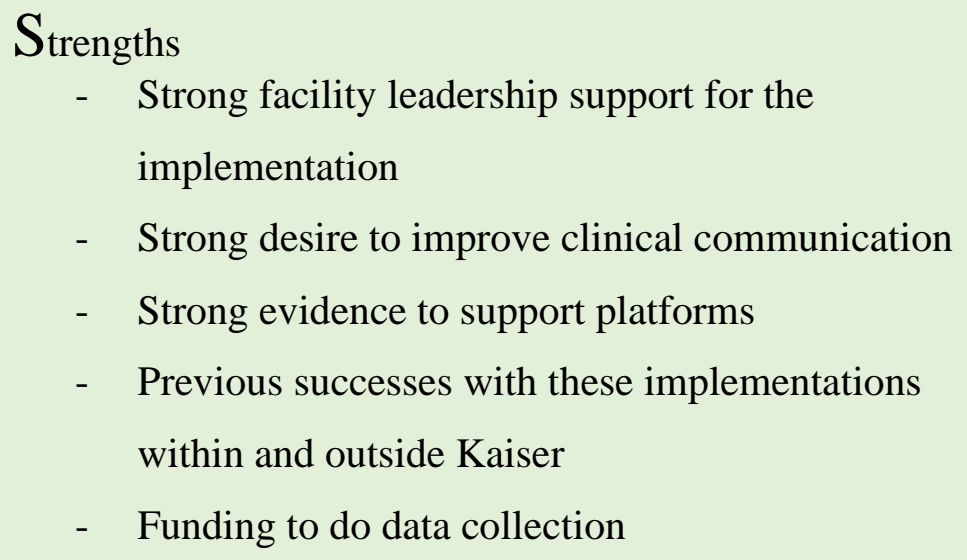 & $\begin{array}{l}\text { Weaknesses } \\
\text { - No policies or procedures in place to guide clinicians } \\
\text { with the new communication methodologies } \\
\text { - No implementation guide for the departments } \\
\text { - Multiple other organizational priorities taking } \\
\text { leadership time away from the go-live preparation } \\
\text { - Each facility going live uses a different } \\
\text { implementation methodology (no standardization) }\end{array}$ \\
\hline 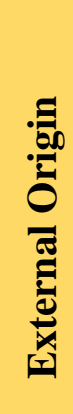 & $\begin{array}{l}\text { Opportunities } \\
-\quad \text { Health system leadership support } \\
\circ \text { To unify the clinical communications } \\
\text { amongst caregivers } \\
\circ \text { To improve quality, safety, efficiency, } \\
\text { clinician and staff satisfaction }\end{array}$ & $\begin{array}{l}\text { Threats } \\
\begin{array}{l}\text { - } \\
\text { - }\end{array} \text { Lacknology problems pre-implementation } \\
\text { implementation } \\
\text { - Lack of ongoing positions to maintain the application }\end{array}$ \\
\hline
\end{tabular}




\section{Appendix M}

\section{Budget}

\begin{tabular}{|c|c|c|c|c|c|c|c|c|c|c|c|}
\hline & & March & April & May & June & July & August & Sept & October & Nov & $\begin{array}{l}\text { Total balance of } \\
\text { expenditure }\end{array}$ \\
\hline \multicolumn{12}{|c|}{$\begin{array}{l}\text { Total funding for } 9 \\
\text { months: }\end{array}$} \\
\hline \multirow{5}{*}{ 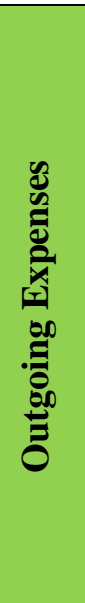 } & $\begin{array}{l}\text { Project Lead } \\
\text { Salary }\end{array}$ & 5,000 & 5,000 & 5,000 & 5,000 & 5,000 & 5,000 & 5,000 & 5,000 & 5,000 & \\
\hline & $\begin{array}{l}\text { Project } \\
\text { Assistant } \\
\text { Salary }\end{array}$ & & & & & & 2,500 & 2,500 & 2,500 & 2,500 & \\
\hline & $\begin{array}{l}\text { Research } \\
\text { Team }\end{array}$ & & & & & & 57,000 & & & & \\
\hline & Travel & & & & & & & 3,000 & & 3,000 & \\
\hline & $\begin{array}{l}\text { Facility Co- } \\
\text { Leads }\end{array}$ & & & & & & & 3,000 & & 3,000 & $\begin{array}{l}\text { * Facility co-leads } \\
\text { paid by facility }\end{array}$ \\
\hline \multicolumn{2}{|c|}{$\begin{array}{l}\text { Monthly Balance } \\
\text { Remaining }\end{array}$} & 135,000 & 130,000 & 125,000 & 120,000 & 115,000 & 50,500 & 40,000 & 32,500 & 22,000 & $+22,000$ \\
\hline
\end{tabular}




\section{Appendix N}

\section{Communication Plan}

\begin{tabular}{|c|c|c|c|}
\hline Communication & Frequency & Goal & Route \\
\hline \multicolumn{4}{|l|}{ Academic Advisors } \\
\hline Committee Chair & Weekly & $\begin{array}{l}\text { Review project status, discuss barriers } \\
\text { and updates, share progress }\end{array}$ & Email, zoom, phone calls \\
\hline Co-Chair/Second Reader & As needed & $\begin{array}{l}\text { To received feedback from draft } \\
\text { prospectus }\end{array}$ & Email, zoom if necessary \\
\hline \multicolumn{4}{|c|}{ Project Sponsors (National IT and Nursing Leadership) } \\
\hline $\begin{array}{l}\text { VP, Care Delivery Technology Services, } \\
\text { National IT Executive Team }\end{array}$ & $\begin{array}{l}\text { Twice a } \\
\text { week }\end{array}$ & $\begin{array}{l}\text { Review project from an IT perspective, } \\
\text { strategize about barriers and facilitators, } \\
\text { provide updates }\end{array}$ & Email and conference calls \\
\hline $\begin{array}{l}\text { Vice President, National Patient Care } \\
\text { Services, Strategy and Operations, } \\
\text { National Nursing Executive Team }\end{array}$ & $\begin{array}{l}\text { Twice a } \\
\text { week }\end{array}$ & $\begin{array}{l}\text { Review project from a clinical } \\
\text { perspective, strategize about barriers and } \\
\text { facilitators, provide updates }\end{array}$ & Email and conference calls \\
\hline \multicolumn{4}{|l|}{ Site (Medical Center) } \\
\hline $\begin{array}{l}\text { Chief Nurse Executive and Leadership } \\
\text { Team, Medical Center }\end{array}$ & Once & $\begin{array}{l}\text { Introduce the project plan and request } \\
\text { participation }\end{array}$ & Phone conference \\
\hline $\begin{array}{l}\text { Medical Center Staff Nurses /leaders of } \\
\text { shared governance councils/nurse managers }\end{array}$ & Once & $\begin{array}{l}\text { Introduce the project plan and request } \\
\text { participation }\end{array}$ & Face-to-face \\
\hline $\begin{array}{l}\text { Medical Center Hospital Based MD Staff } \\
\text { (HBS) Leadership }\end{array}$ & Once & $\begin{array}{l}\text { Introduce the project plan and request } \\
\text { HBS participation }\end{array}$ & Face-to-face \\
\hline Letter to participants and letter to leaders & Once & & \\
\hline Clinical Informatics Specialist, KP-MCX & $\begin{array}{l}\text { Twice a } \\
\text { week }\end{array}$ & $\begin{array}{l}\text { Discuss project, request participants, co- } \\
\text { ordinate pre and post implementation site } \\
\text { visits }\end{array}$ & Phone conference \\
\hline \multicolumn{4}{|l|}{ Research Team } \\
\hline $\begin{array}{l}\text { Primary Research Leader } \\
\text { Adjunct Researcher }\end{array}$ & $\begin{array}{l}\text { Twice a } \\
\text { week }\end{array}$ & $\begin{array}{l}\text { Discuss data collection methodology and } \\
\text { analysis plan }\end{array}$ & $\begin{array}{l}\text { Phone conference and } \\
\text { face-to-face }\end{array}$ \\
\hline
\end{tabular}




\section{Appendix O}

\section{Manager Letter of Participation}

To: Clinical Leadership at Medical Center.

From: National Facilities Services and the User Experience (UX) Research and Design Team

Subject: We are reaching out to select Clinical Leadership at Medical Center to help us with an exciting opportunity! |

With the upcoming Go-Live of Vocera technology and devices for staff, we are conducting a special effort to measure successes and opportunities for improvement of this new communications tool. This will be done through interviews, focus groups and shadowing. With this data collection effort, it will provide us the ability to quantify through careful data collection what is working and what is not working for clinicians before and after the go live. Learnings will be shared with leadership, IT and others who have influence over technology and tool decisions for all our staff throughout the Nation.

To conduct this effort, we are asking for your help in recruiting participants to work with our Researchers. We are looking for staff who are most representative of the common "end-user" population.

- Participants will have the opportunity to have a one-on-one hour-long interview with a UX Researcher and/or attend a lunchtime Focus Group with peers and/or be shadowed for 3 hours by a UX Researcher

- All sessions will follow anonymous data collection practices, and feedback will not be associated back to any individual clinician

- Participation will not impact employment status or be a measure of individual staff member performance in any way

- Lunch will be provided at focus group sessions

- Shadowing activities will not impact care delivery

- Sessions will be conducted pre and post your go-live at the

Medical Center

Gathering insights directly from end users is critical to making sure the right technology is provided for clinical care delivery. For this reason, engagement with your staff is essential to the project's success.

Please share names of individuals you believe would be a good fit for this activity and reach out if you have any questions.

Thank you in advance,

For questions, please email michellem.machon@ or by phone at 


\section{Appendix P}

\section{Staff Letter of Participation}

Dear Staff at $\longrightarrow$ Medical Center.

From: National IT Facilities Services and the End User (UX) Research and Design Team

Thank you for agreeing to participate in this exciting opportunity to work with us in collecting data on the usage of Vocera and its outcomes with effectiveness of communication amongst the healthcare team.

We are conducting a special effort to measure successes and opportunities for improvement of this new communication tool, through interviews, focus groups and shadowing. This will be an opportunity to quantify through careful data collection what is working and what is not working for clinical staff such as yourself, before and after the go live. Learnings will be shared with Leadership, IT and others who have influence over technology decisions for all our staff throughout the Nation.

To conduct this effort, we are asking you to volunteer and participate in any or all of the following formats:

- One-on-one 60-minute interviews with a UX Researcher and/or

- Lunchtime Focus Groups with peers and/or

- To be shadowed at work for 3 hours by a UX Researcher

\section{Please note}

- All sessions will follow anonvmous data collection practices, feedback will not be associated back to anv individual clinician

- Participation will not impact employment status at $\square$ or be a measure of individual staff member performance in any way

- Lunch will be provided at focus group sessions

- Shadowing activities will not impact care delivery

- Sessions will be conducted pre and post go-live at the $\square$ Medical Center.

Gathering insights directly from clinicians like yourself is critical in making sure the right technology is provided for the delivery of care at our facilities. For this reason, engagement with clinical end-users is essential to project success.

Please work with the project coordinators to sign up for a session time that fits your schedule and we will send a calendar invite and details shortly. Feel free to reach out if you have any questions to michelle.m.machon@ 


\section{Appendix Q}

Cost/Benefit Analysis

Cost Avoidance Estimates from IECCS Soft to Hard Dollar Summary Based on Local Variable Cost Only Data

\section{Hospital Throughput Improvement}

Based on Avera Health reduction in discharge time by 22 minutes

\begin{tabular}{lc} 
2019 Annual M/S/T Discharges & 13,404 \\
$\begin{array}{l}\text { Saved Time per Discharge } \\
\text { (Hours) }\end{array}$ & 0.37 \\
& \\
Total Time Saved (Hours) & $4,914.80$ \\
& \\
RN Hourly Wage (5\% OT) & $\$ 98.70$ \\
M/S/T RN Nursing Ratio & 0.222 \\
(1:4/1:5) & $13 \%$ \\
Break/Lunch Burden & $24 \%$ \\
Non-Prod Burden & $42.80 \%$ \\
T\&B Burden (KFH) & $\$ \mathbf{\$ 4 3 . 8 9}$ \\
RN Variable Cost/Hour & \\
\hline Total Annual Savings & $\mathbf{\$ 2 1 5 , 6 9 4}$ at Facility R \\
\hline
\end{tabular}

\section{Improve OR Efficiency}

Based on Major Health Partners - 5 minutes saved per case
2019 ROS/FOL Surgical Cases

19,500

Saved Time per Case (Hours)

0.08

Total Time Saved (Hours)

$1,625.00$

RN Hourly Wage (5\% OT)

$\$ 98.70$

Scrub Tech Wage (5\% OT)

$\$ 49.35$

In-room RN staff as \% of

$\mathrm{RN} / \mathrm{Scrub}$

$55 \%$

Combined in-room hourly wage

$\$ 152.99$

Break/Lunch Burden

$13 \%$

Non-Prod Burden

$24 \%$

T\&B Burden (KFH)

$42.80 \%$

In-Room RM/Tech Cost/Hour 


\begin{tabular}{|l|r|}
\multicolumn{1}{c|}{ (\$ millions) } & \\
\hline \multicolumn{1}{c|}{ Benefit Description } & $\begin{array}{r}\text { Total Value* } \\
\text { (2022-2026) }\end{array}$ \\
\hline Hospital Throughput Improvement & $\$ 20.75$ \\
\hline Improve OR Efficiency & $\$ 47.85$ \\
\hline Soft Benefits Sub-Total & $\$ 68.60$ \\
Grand Total Benefits & $\$ 68.60$ \\
\hline
\end{tabular}

Note: $\$ 68.6$ million dollar benefit relates to Grand Total Benefits multiplied by the 39 hospitals in the health system. 


\section{Appendix R}

\section{Fieldwork Guides}

\begin{tabular}{|c|c|c|}
\hline $\begin{array}{l}\text { IHC } \\
\text { Shadowing Data Sheet }\end{array}$ & \multicolumn{2}{|c|}{$\begin{array}{l}\text { Participant\# } \\
\text { Participant Role: __ Researcher_ } \\
\text { Date: } \\
\text { Start Time: }\end{array}$} \\
\hline ACTIVITY/TIMING & \multicolumn{2}{|r|}{ NOTES \& OBSERVATIONS } \\
\hline \multicolumn{2}{|c|}{$\begin{array}{l}\text { Time/Experience to Contact Provider } \\
\text { Time/Experience to Contact Team Member } \\
\text { Time/Experience to Contact Help } \\
\text { Time/Experience to Discharge Patient } \\
\text { Other: }\end{array}$} & $\begin{array}{l}\text { Purpose: } \\
\text { Location Changes: }\end{array}$ \\
\hline \multicolumn{2}{|c|}{$\begin{array}{l}\text { TIMING DATA: (Capture Start and End Times, if } \\
\text { activities occur between Start and End, capture } \\
\text { and event could include time to receive reply, } \\
\text { for example) }\end{array}$} & Pain Points/Delays: \\
\hline $\begin{array}{l}\text { EVENT: } \\
\text { EVENT: } \\
\text { EVENT: } \\
\text { END: }\end{array}$ & 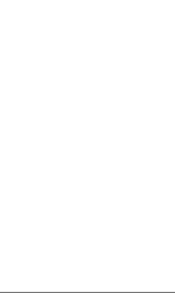 & What Signified end of Task: \\
\hline \multicolumn{2}{|c|}{$\begin{array}{l}\text { Time/Experience to Contact Provider } \\
\text { Time/Experience to Contact Team Men } \\
\text { Time/Experience to Contact Help } \\
\text { Time/Experience to Discharge Patient } \\
\text { Other: }\end{array}$} & $\begin{array}{l}\text { Purpose: } \\
\text { Location Changes: }\end{array}$ \\
\hline \multicolumn{2}{|c|}{$\begin{array}{l}\text { TIMING DATA: (Capture Start and End Times, if } \\
\text { activities occur between Start and End, capture } \\
\text { and event could include time to receive reply, } \\
\text { for example) }\end{array}$} & $\begin{array}{l}\text { Devices Used: } \\
\text { Pain Points/Delays: }\end{array}$ \\
\hline $\begin{array}{l}\text { START: } \\
\text { EVENT: }\end{array}$ & & Pain Points/Delays: \\
\hline \multicolumn{2}{|l|}{ EVENT: } & What Signified end of Task: \\
\hline
\end{tabular}




\section{IHC (Integrated Hospital Communications) Focus Group Guide 09.16.19}

\begin{tabular}{|l|l|l|l|}
\hline Date & Time & Provider & Provider Role / Specialty/ Location \\
\hline & & & \\
\hline & & & \\
\hline & & & \\
\hline & & & \\
\hline
\end{tabular}

Methodology

Method: 60-minute focus groups with 5-7 Care Delivery Staff in person and recorded.

Participants KP-MCX Care Delivery Staff

Assumptions, Requirements, Dependencies: Access to care delivery staff. Regional assistance to identify staff. Access to location to hold focus group.

Goals

The IHC focus group is to understand what is working well or not so well for communications, so we can identify any insights, pain points and/or barriers to communications for the present state.

Provider Consent Forms

Consent Form: https://www.surveymonkey.com/r/SHD7CZ2

Release Form: https://www.surveymonkey.com/r/SHC5FQ3

Focus Group Checklist

- KP iPhones to record (2)

- Computer to display deck

- Projector

- iPad for consent forms

- Badge Clips/Thank Yous

- Antibacterial wipes(1)

- Mac projector cable

\section{Facilitator 1 Duties}

- Provide introduction

- Present Slides and provide talking points

- Ask primaryquestions

- Ask secondary/probing questionsas needed
- Provide closing remarks

Facilitator 2 Duties

- Clean and prep food serving areas as needed

- Make sure food is set up and easy to access

- Arrange room in away that facilitates conversation

- Take notes during discussion

- Ask secondary/probing questions as needed

- Pass out thank you cards as providers exit 


\section{IHC Focus Group Guide}

Welcome and Introduction (5 min)

Thank you for coming! My name is [1. I'm a User Experience Researcher, on the User Experience group at Kaiser Permanente. I am here with my colleagues [1, other User Experience Researchers, who will be taking notes. The purpose of this focus group is to help us understand your experience with clinical communications here at KP-MCX what is working well or not so well with the tools you use for communications, so we can identify any insights, pain points and/or barriers in communication workfiows.

We are not familar with all the processes for your specific communications, so some of the questions we wil ask you might involve you walking us through some of these processes. This focus group should take about 60 minutes. Should the conversation run a few minutes later, anyone with a hard stop is encouraged to depart when they need to.

Anything we discuss or you share today is confidential and will only be used to help the UX team work on improving the communications experience for care delivery staff like you. Your name will not be associated with any information that you provide. We are recording today's session in order to capture all of your insights. Our recordings are password protected and wil be kept in a secure fle and location.

We encourage you to freely provide your honest input today so that we can better understand things that work and don't work for you. This is not a test, and there are no wrong answers, just differing points of view. The sole purpose of today's meeting is to evaluate communication systems. Feel free to discuss your opinion even if it varies from what others have said. Negative comments are just as appreciated as positive, and can often be the most helpful in terms of assessing the application.

There are iPads floating around with a consent form and a release form. Please sign these before you leave. Any of us can help you or answer any questions related to these forms. They are standard practice for our team any time we engage with KP end users like you.

Are there any questions before we get started?

Great, let's begin.

I'm going to start the recording, okay?

[start recording] 
Discussion with Participants

General(3 minutes)

We would like to get to know a little more about you. Let's start with quick around the room to hear what your role is here at $\mathrm{KP}$.

Unders tonding Workflows (10 min)

First we would like to hear a little bit about communications you need to do to provide care.

Do you mind sharing one of your most common communications workflows? Who do you communicate with? What defines a successful communication for you for this scenario? We am not interested in how you complete these communication workflows, but rather who and what you need to communicate.

(repeat this ask until all the common workflows are defined)

Who they communicate with?

What the objective is of the communication?

Unders tonding Devices and Tools ( $5 \mathrm{~min}$ )

Great, so now let's talk a little about the tool you use for care delivery communications.

What devices do you use? What software or tools do you use?

Think back to the workflows you shared, have you mentioned all of the tools you use to complete these tasks?

Unders tanding Devices and Tools (10 min)

5o, what is working/what is not working when you perform these communications workflows with the tools you are provided?

Make sure they touch on pain points with the workflows and with the devices/tools

Impact to Patient Satisfaction (10 min)

How do the pain points you described impact Patient Satisfaction? Can you share examples? 
How would you? (5 $\mathrm{min})$

Reference the pain points, ask them how they would address those pain points. What are their ideas for improvement?

Follow - up Questions (As Needed)

- Can you tell me more about that?

- Can you tell me in what context that would occur?

- Can you tell me more about that workfiow?

- What is your objective during that process?

- Is this an issue during a patient encounter?

- How would you handle the issue in an office visit?

Bringing the Discussion Back (As Needed)

- Thanks for sharing your perspective. Going back to [theme].

- I can see why that would be frustrating/annoying/etc. We will add this finding to our notes. Let's discuss a little more about [theme].

Closing Remarks ( 2 minutes)

- Thank you very much for taking the time to participate today. Your responses and feedback are very valuable and helpful. Have a great rest of your day! 


\section{IHC Interview Guide}

Date:

Role:

1. What is your role?

2. What is your age? (optional)

3. What are the most common communications you need to do to provide care? (who, end goal) What tools do you use for care delivery related communications (hardware \& software)?

5. Do the devices you described require maintenance? If so, ask the user to share details |

6. Are these devices reliable? If not, ask the user to share details. How do these tools support you with care delivery communications? (usefulness)

8. How did you learn how to use this technology? (probe if training was sufficient) (learnability) What are the biggest challenges you face with communications you need to do your job? (ease of use/efficiency/usefulness/quality)

10. How do the tools provided aide you with communications you need to do to do your job? (ease of use/efficiency/usefulness/quality)

11. From your experience, how do the tools you use for communications support or not support perceived member and caregiver satisfaction?

12. From your experience, how do the tools you use for communications support quality and safety

Now I am going to read you a few statements to summarize what you have shared. Rate each statement on a scale of 1 to 10,10 being highest.

- The communications tools I am provided support efficient and effective care delivery communications.

- The communications tools I am provided support patient/caregiver satisfaction.

- The communications tools I am provided are reliable.

- The communications tools I am provided are maintenance free.

- The communications tools I am provided are efficient.

- The communications tools I am provided result in efficient turnaround times.

- The communications tools I am provided support quality communications.

- The communications tools I am provided support care team engagement.

- The communications tools I am provided support patient safety.

\section{What if...}




\section{Appendix S}

\section{Index of Topics from Implementation Guide}

Kaiser Permanente Integrated Enterprise Clinical Communication Strategy (IECCS) Clinical Communication Step by Step Implementation Guide for Facility Leads

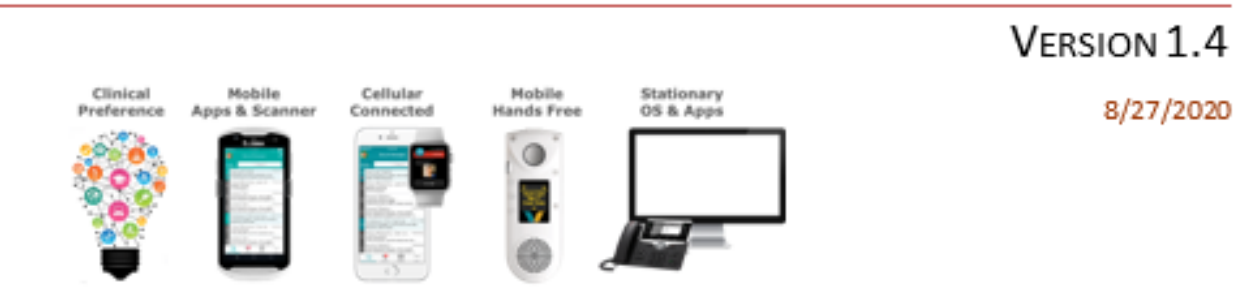


Table of Contents

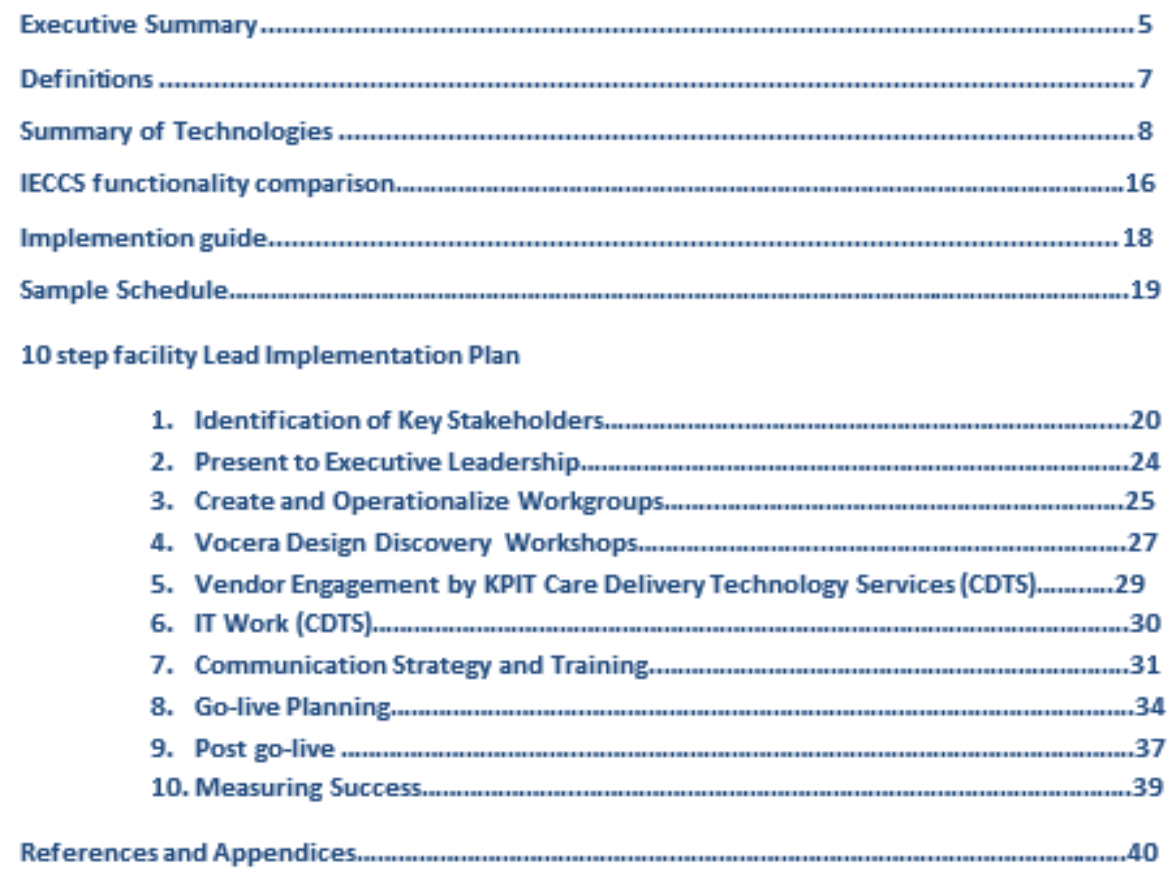




\section{Appendix T}

\section{Implementation Guide Online Survey}

\section{IECCS "Implementation Guide" Feedback}

* please note, the terms IHC (Integrated Healthcare Communications) and IECCS (the new name for the program- Integrated Enterprise Clinical Communication Strategy) are used interchangeably in this survey)

1. Is your Facility/Region

Already live with IHC/IECCS?

Planning to go live with IHC/IECCS in the future?

Other (please specify)

2. This Implementation Guide provides all the details I need as a nurse leader responsible for an IECCS implementation.

Strongly Agree

Agree

Neither agree nor disagree

Disagree

Strongly Disagree

Please detail any items you might feel are missing? 
3. This guide would have assisted me during my facility's s implementation of IHC/Vocera.
Strongly agree
Disagree
Agree
Strongly disagree
Neither agree nor disagree
Not Applicable

4. This guide will be a useful resource for facilities going live with IECCS in the future.
Strongly agree
Disagree
Agree
Strongly disagree
Neither agree nor disagree
Comments:

5. I foresee there will be challenges using this guide.
Strongly agree
Disagree
Agree
Strongly disagree
Neither agree nor disagree

What challenges might you foresee using this guide?

6. Please add any comments (in as much detail as possible) you may have about this Implementation Guide? 


\section{Appendix U}

\section{Project PDSA Cycle}
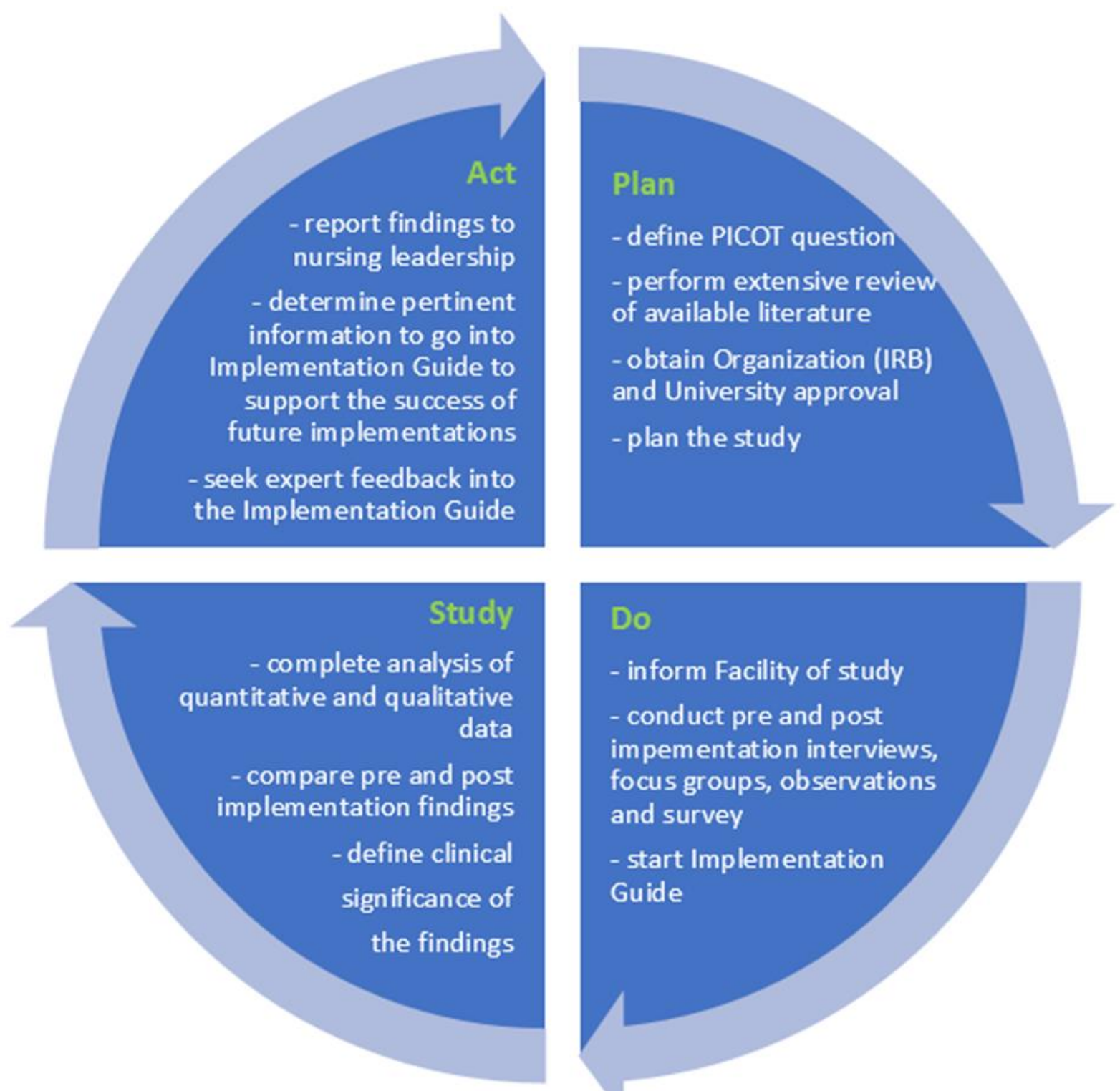

Do

- inform Facility of study

- conduct pre and post impementation interviews, focus groups, observations and survey

- start Implementation Guide 


\section{Appendix V}

\section{Letter of Non-Research Determination}

\section{InterOffice Memorandum}

\section{Organization Logo}

$8 / 7 / 2019$

Michelle Machon, MSN
Practice and Informatics

Re: "Collection of pre and post Vocera Implementation Data at

Medical Center"

Dear Ms. Machon,

A designated reviewer on the

(KPSC) Institutional

Review Board (IRB) reviewed your submission and determined that this is not human subjects research as defined by 45 CFR 46.102 (e)(1) and (I). Therefore, IRB review of this project is not necessary.

Sincerely,

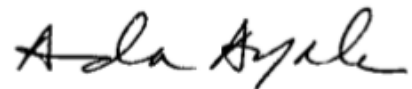

Armida Ayala, MHA, $\mathrm{PhD}$

Director of Human Research Subjects Protection

Office/Institutional Review Board (IRB) 


\section{Appendix W}

\section{Letter of Organizational Permission}

\section{Organization X}

Sept 9, 2019

School of Nursing.

University of San Francisco

To whom it may coscern.

Please acoept this letter as my support and approval for Michelle Marie Machon to implement her Doctor of Nursing Practice Comprehensive Projoct at Michelle's project is to collect data pre and post implementation of the Vocera coenmunication system at the Ka-Mox Medical Center in Southem California. She has received a determination by the California Institutional Review Board (IRB) that this project is not human subjocts research and therefore IRB review of this project is not necessury.

This letter also verifies that - University of San Francisco's School of Nursing.

Thank you,

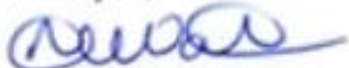

DNP, MSHCA, RN, CENP

Vice President, Strategy and Operations

National Patient Care Services 


\section{Appendix X}

\section{DNP Statement of Non-Research Determination}

UNIVERSITY OF Schoo of Nursinc and

SAN FRANCISCO Hoalth Protessrays

DNP Statement of Non-Research Determination Form

Student Name: Michelle Machon

Tifle of Project:
Fffects of implementing a unified clinical communication platform in a hospital setting
Brief Description of Project:

A) Aim Statement:

The aim of this project is to determine the eflectiveness of the implementation of a unificd clinical communication platform in an acute care hospital setting.

B) Description of Intervention:

1. the intervention will replace old technology (Cisco/spectralink) phones for aurses with a smart device that has voice, alerts/alarms and the Vocera Collaboration Suite (VCS) and will add the VCS App to the MD iPhones.

2. VCS will provide:

- Voice

- Instant messaging

- Clinical directory with ability to see who is in the hospital at any given time

- Group messaging

- Role based calling and messaging (e.g. "call hospitalist on duty" of "call ICU Respiratory Therapist")

- Alert and alarm delivery

- On-call directory

C) How will this intervention ehange practice?

It is the expectation that the technology will improve communication between clinicians. Other hospitals that have implemented this platform have reported improvements in communication, efficiency, patient and staff satisfaction.

D) Outcome measurements:

Outcomes will be measured through:

1. Interviews

- In depth interviews about current communication methodology strengths, weaknesses and opportunities (pre and post implementation) 
- Plan for approx, 4 participants from each group (RN, MD, Phamacy, UAs)

- Communication to be sent to all staff: they would be asked to volunteer and would be informed that no names would be associated with the data, it would be voluntary, no personal identifiers would be recorded and none of the information or content would be reported to management etc.)

2. Observations /time and motion

- Following the same types of participants above, we would observe staff in their normal day to day work (unchanged standard of care) to determine the amount of time they spend in a given shift on communication

- Target observations examples include

- Time spent reaching out to Provider

- Time waiting for response

- Interdepartmental communication time

- Time spent communicating about transferring patients

- Time spent by UA finding RN or other team members

- Time spent communicating during emergencies

3. Data collection from information/metrics already available. Some examples include:

- Number of overhead pages

- ED to inpatient admission time

- Nurse satisfaction (e.g. satisfaction with technology)

- Patient satisfaction (e.g. quiet at night)

- Number of calls madeimessages sent

4. An online survey

- A survey about the communication practices at Downey would be administered to all patient care services staff, seeking staffs perceived satisfaction with the pre and post implementation methodologies. Survey would be sent to all staff listed above via survey monkey and staff would be informed their response would be anonymous with no personal identifiers captured.

5. Focus Groups

- Take a piece of information and see how it flows through the care team

- focus group to get a discussion going with all entities in the room - using a flow diagram/process mapping using lean methodology to capture the data.

To qualify as an Evidence-based Change in Practice Project, rather than a Research Project, the criteria outlined in federal guidelines will be used:

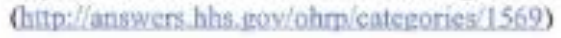

X This project meets the guidelines for an Evidence-based Change in Practice Project as outlined in the Project Checklist (attached). Student may proceed with implementation.

This project involves research with human subjects and must be submitted for IRB approval before project activity can commence.

Comments:

EVIDENCE-BASED CHANGE OF PRACTICE PROJECT CHECKLIST * Instructions: Answer YES or NO to each of the following statements:

\begin{tabular}{|c|c|c|}
\hline Projeet Title: & Yes & No \\
\hline $\begin{array}{l}\text { The aim of the project is to improve the process or delivery of care with establisbed } \\
\text { accepted standards; or to implement evidence based change. There is no intention of } \\
\text { using the data for research purposes. }\end{array}$ & $\mathrm{x}$ & \\
\hline $\begin{array}{l}\text { The specific aim is to improve performance on a specific service or program and is a } \\
\text { part of usual care. ALL. participants will receive standard of care. }\end{array}$ & $\mathrm{x}$ & \\
\hline $\begin{array}{l}\text { The project is NOT designed to follow a research design, e.g, hypotbesis lesting or } \\
\text { group comparison, randomization, control groups, prospective comparison groups, } \\
\text { cross-sectional, case control). The project does NOT follow a protocol that overrides } \\
\text { clinical decision-making. }\end{array}$ & $x$ & \\
\hline $\begin{array}{l}\text { The project involves implementation of established and tested quality standards } \\
\text { and/or systematic monitoring, assessment or cvaluation of the organization to ensare } \\
\text { that existing quality standards are being met. The project does NOT develop } \\
\text { paradigms or untested methods or new untested standards. }\end{array}$ & $\mathrm{x}$ & \\
\hline
\end{tabular}




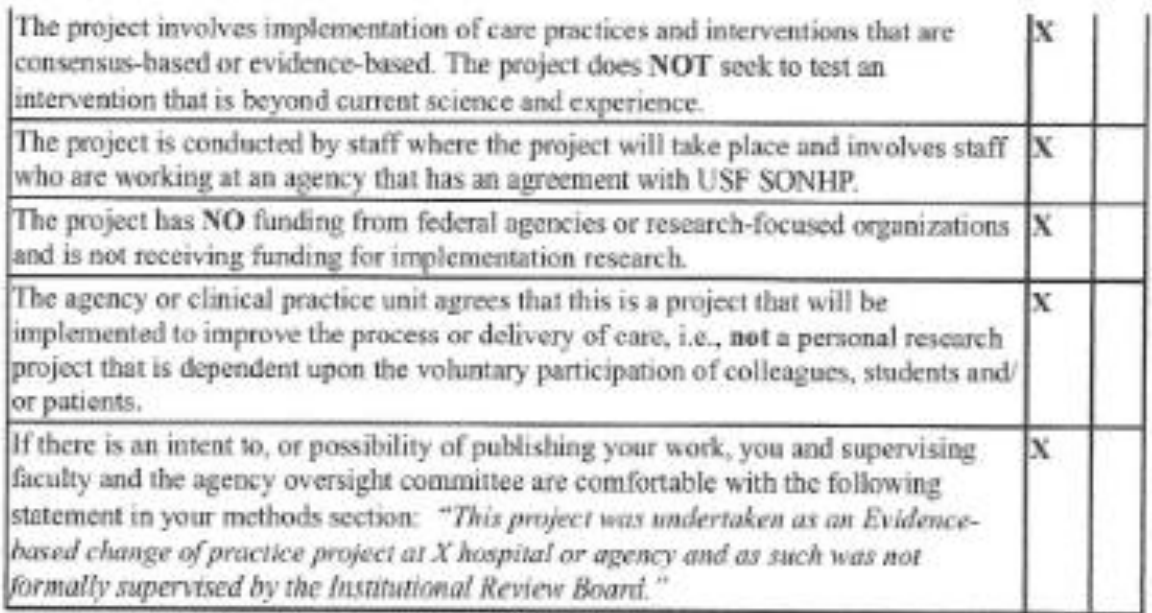

ANSWER KEY: If the answer to ALL of these items is yes, the project can be considered an Evidence-based activity that does NOT meet the definition of research. IRB review is not required. Keep a eopy of this ehecklist in your files. If the answer to ANY of these questions is NO. you must submit for IRB approval.

*Adapted with permission of Elizabeth L. Hohmann, MD, Director and Chair, Partners Human Research Committee, Partners Health System, Boston, MA.

STUDENT NAME (Please print): MICHELLE MACHON

Signature of Student: $7 /$ ichelle $1 /$ as DATE august 7 th 2019

SUPERVISING FACULTY MEMBER (CHAIR) NAME (Please print): Mary Lynne Knighten, DNP, RN, NEA-BC

Signature of Supervising Faculty Member (Chair): Dh. Nanelyone trigfien DATE October 14, 2019

1 


\section{Appendix Y}

\section{Qualitative Data Collection: Verbatim Interview Responses}

\begin{tabular}{|c|c|c|}
\hline & Pre-Implementation & Post-Implementation \\
\hline Interviews & $\begin{array}{l}\text { Before implementation, staff said their analog phones } \\
\text { "are not perfect, but they work" and were "pretty much } \\
\text { self-explanatory" with little training needed. However, } \\
\text { they reported that they broke easily, had static during } \\
\text { calls, frequently turned off for no reason, and staff stated } \\
\text { it's "challenging if I can't get a hold of a doctor right } \\
\text { away." Staff had developed many workarounds for when } \\
\text { the analog phones did not work. Finally, they said the } \\
\text { challenge with the current system was "to know how to } \\
\text { contact physicians: some want calls, some don't, a } \\
\text { process for escalation is not defined." When asked what } \\
\text { they wanted from a new communication system, they } \\
\text { stated they wanted a modern, single, reliable device (like } \\
\text { their home phones) with better connectivity, better alarm } \\
\text { management, and a way to know the priority of } \\
\text { communication workflows. }\end{array}$ & $\begin{array}{l}\text { Staff stated that "in the beginning it was chaos," but then } \\
\text { said that there was "improvement over time." Other } \\
\text { positive comments included the longer battery life, the } \\
\text { benefits of mobility, and the texting capabilities. Part of } \\
\text { the technology implemented was the ability to send } \\
\text { secure messages to the care team, and this was probably } \\
\text { the most well received functionality by staff, as was the } \\
\text { ability to do role-based calling and "not having to } \\
\text { memorize phones numbers anymore." For the messaging } \\
\text { application, staff "like that you can see the roles, you can } \\
\text { look up a role like ED Room } 5 \text { Nurse." However, the } \\
\text { negative comments outweighed the positives on } \\
\text { interview, with themes including frustration, chaos, and } \\
\text { unreliability. One participant stated, "It's still not running } \\
\text { smooth, we've had what, a month, and it's still very } \\
\text { frustrating." The Wi-Fi connectivity was a repeated } \\
\text { theme in the interviews, and one nurse reported, "A } \\
\text { physician may be signed in, but may be in a dead space }\end{array}$ \\
\hline
\end{tabular}




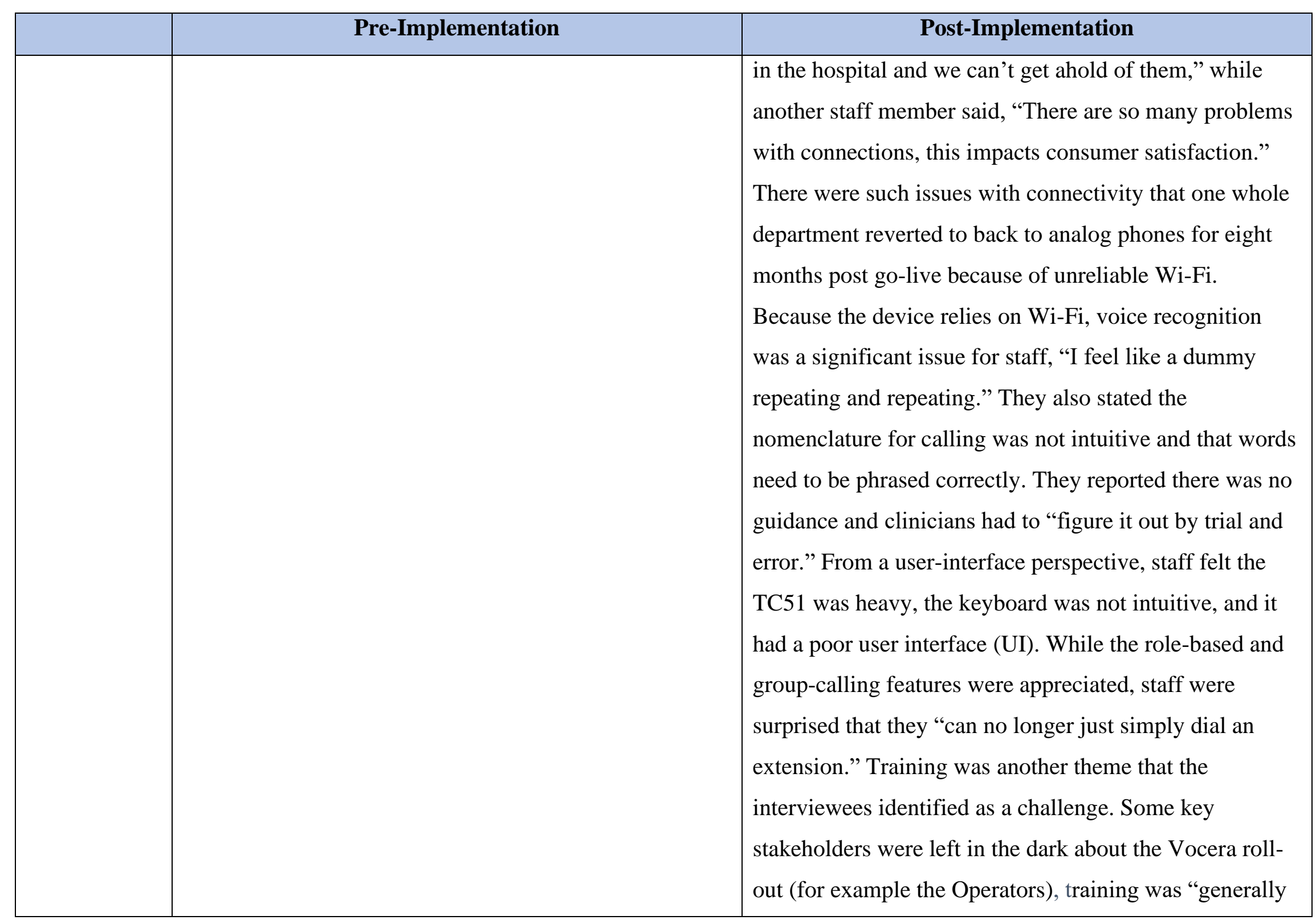




\begin{tabular}{|c|c|c|}
\hline & Pre-Implementation & Post-Implementation \\
\hline & & $\begin{array}{l}\text { insufficient and not attended by all users," and there were } \\
\text { training gaps, where again, some nurses felt they had to } \\
\text { "figure it out" on their own. Operationally, staff stated } \\
\text { that others were not signing themselves in properly; } \\
\text { therefore, you could not get ahold of them, and while } \\
\text { most operational workflows remained the same for users, } \\
\text { some staff were never converted off the analog phones, } \\
\text { and this was confusing for clinicians. A final theme } \\
\text { identified was end-user go-live support, which staff felt } \\
\text { was lacking: "My understanding was that there was } \\
\text { going to be people on the floor for a week. Any } \\
\text { questions, we would see them, call them, or get their } \\
\text { attention, whatever, and they would help us... but there } \\
\text { was nobody. Basically, I felt like here's the phone, } \\
\text { done." }\end{array}$ \\
\hline $\begin{array}{l}\text { Focus } \\
\text { Groups }\end{array}$ & $\begin{array}{l}\text { In the pre-implementation focus groups, nursing staff } \\
\text { said they had frustrations with the analog phones as "not } \\
\text { all staff have them" and more importantly, "when we } \\
\text { need a physician quickly, we send them multiple } \\
\text { messages and sometimes they can't get through to them } \\
\text { at all." They also were disturbed with the older }\end{array}$ & $\begin{array}{l}\text { Staff had both positive and negative elements to report } \\
\text { post-implementation. The ability to send secure "text" } \\
\text { messages after implementation was the number one } \\
\text { benefit reported by nurses, and they even reported, "It } \\
\text { holds people a little bit more direct-accountable: I sent } \\
\text { you a text at this time." Yet, nurses in the focus groups }\end{array}$ \\
\hline
\end{tabular}




\begin{tabular}{|c|c|c|}
\hline & Pre-Implementation & Post-Implementation \\
\hline & $\begin{array}{l}\text { functionality: batteries that did not last a whole shift, } \\
\text { phones that shut off for no reason, and a speaker setting } \\
\text { that was loud enough to disturb patients. The feedback } \\
\text { from the ward clerk, physician, and pharmacist pre- } \\
\text { implementation focus groups were similar. One ward } \\
\text { clerk stated: "It is hard for us to find a nurse if they don't } \\
\text { have a phone because we have to check each room they } \\
\text { are assigned to." A pharmacist said: "If paging doesn't } \\
\text { work, then Skype, then the operator, then Cortext, then } \\
\text { call - we have to use multiple methods before getting } \\
\text { through." One physician stated: "We need one system so } \\
\text { we don't have to carry multiple devices." }\end{array}$ & $\begin{array}{l}\text { also reported the call-quality and voice recognition as } \\
\text { poor, alarm fatigue was not ameliorated, and while they } \\
\text { reported the issues in Labor and Delivery where they } \\
\text { went back to the analog phones due to the connectivity } \\
\text { issues, they also said some departments were carrying the } \\
\text { new devices and the old analog phones due to reliability } \\
\text { concerns. While the other focus groups reported benefits, } \\
\text { like the ability to see who called you, the secure } \\
\text { messaging, and not having to go through the operator or } \\
\text { ward clerk, the issues of staff not signing into Vocera, } \\
\text { the confusion over not having numbers, sub-adequate } \\
\text { training, and the poor reception were still concerns. The } \\
\text { physician focus group also noted that "only 10-20\% of } \\
\text { users are properly logged in," as well as the unhappy } \\
\text { surprise that anyone could call them directly, and they } \\
\text { had no ability to "triage" calls like they previously did } \\
\text { with pagers. }\end{array}$ \\
\hline Observations & $\begin{array}{l}\text { Pre-implementation shadowing demonstrated the manual } \\
\text { workflows that staff had put in place to communicate, } \\
\text { including writing their extension on visual boards at the } \\
\text { nurses' station and physicians walking by that board to }\end{array}$ & $\begin{array}{l}\text { Post-implementation shadowing echoed the positive } \\
\text { findings of the interviews and focus groups, including the } \\
\text { value of secure messaging, the ability to take pictures, } \\
\text { and to broadcast messages to groups of staff. End-users }\end{array}$ \\
\hline
\end{tabular}




\begin{tabular}{|c|c|c|}
\hline & Pre-Implementation & Post-Implementation \\
\hline & $\begin{array}{l}\text { see the numbers. The data obtained included observing } \\
\text { the challenges of the older broken analog phones and the } \\
\text { noise level of the emergency department. The need for } \\
\text { the triaging of calls through the ward clerk was noted, as } \\
\text { well as the subsequent chaotic environment when no } \\
\text { ward clerk was on duty. }\end{array}$ & $\begin{array}{l}\text { reported other benefits, like the ability to set and call } \\
\text { from a favorites list, and that "Vocera allows for more } \\
\text { organized communication." However, the negatives were } \\
\text { evident in the shadowing experiences, including "contact } \\
\text { method overload," meaning the negative side of the } \\
\text { number of ways staff now had to contact each other. } \\
\text { Confusion over who was on Vocera versus still on analog } \\
\text { phones, frustration with voice recognition, usability } \\
\text { issues with no phone numbers to dial, and training } \\
\text { problems were all noted during direct observations. }\end{array}$ \\
\hline Surveys & $\begin{array}{l}\text { Pre-implementation one physician expressed their } \\
\text { trepidation for using Vocera at KP-MCX, stating they } \\
\text { had used it at other facilities, and it was "faulty and } \\
\text { unreliable." Other clinicians stated they simply wanted } \\
\text { one device and something more "versatile" than the } \\
\text { "outdated" analog phones. }\end{array}$ & $\begin{array}{l}\text { Post-implementation survey comments were } \\
\text { overwhelmingly negative and were found to correlate to } \\
\text { the following themes: poor connectivity, poor quality } \\
\text { calls, a poor rollout, inadequacies in training, and } \\
\text { difficulties using the badge genie. The form factor of the } \\
\text { device was the subject of multiple comments, including } \\
\text { the size, weight, multiple steps to make a call, the login, } \\
\text { and difficulties with the user interface. }\end{array}$ \\
\hline
\end{tabular}

